\title{
IPM POTENTIALS OF MICROBIAL PATHOGENS AND DISEASES OF MITES
}

\author{
LEO P. S. VAN DER GEEST \\ IBED, Section Population Biology \\ University of Amsterdam, \\ $1098 S M$ \\ Amsterdam, The Netherlands
}

\begin{abstract}
An overview is given of diseases in mites, caused by infectious microorganisms. Many pathogens play an important role in the regulation of natural populations of mite populations and are for this reason subject of research on the feasibility to develop such pathogens to biological control agents. Several examples are given of successful application of pathogens for the control of mite pests, but also failures are discussed. Most studies concern fungal pathogens of tetranychids and eriophyids; some of these fungi are possible candidates for biological control agent of species of noxious mites. An interesting group of pathogens form the intracellular symbionts: bacteria that may cause unusual effects in their hosts, such as parthenogenesis, feminization, male killing and incompatibilities. This group of bacteria is present in many invertebrates species and are presently widely studied as new molecular techniques have become available that make detection of such symbionts possible. Attention is also given to quality control of beneficial mites that are being used in integrated control programs. Beneficial mites, as e.g. predatory mites, may also be infected by microorganisms (bacteria, viruses, microsporidia), resulting in poor performance of the predator. Prospects for the application of pathogens in IPM systems are discussed.
\end{abstract}

\section{INTRODUCTION}

As other organisms, Acari may also be subject to disease, usually caused by pathogenic microorganisms. Our knowledge on pathogens of mites, however, is still fragmentary, in contrast to what we know about pathogens of insects. The rapid development of invertebrate pathology in the second half of the twentieth century has largely been due to the study of insect pathogens. Relatively few mite pathogens are known, despite the large number of mite species. Approximately 48,000 species have hitherto been described and it is estimated that this number represents only $10 \%$ of the total number of mite species.

That mite pathogens have been studied less comprehensively is not surprising: their frequently small size renders disease diagnosis often difficult and pathophysiogical studies almost impossible. From the other hand, the often large 
reproductive potential of mites makes many acarine species ideal model organisms for detailed epidemiological investigations.

Pathogens in populations of mite species often play a major role in the regulation of population size and population density in natural habitats. In several instances, we see that populations of pest species in agricultural systems are kept below the economic threshold level by the occurrence of a disease. Such observations often provide impetus for further studies on the pathogen involved that may eventually lead to the successful application of a pathogen for the biological control of a mite pest. In addition, the occurrence of disease may be undesirable, e.g. in the case of cultures of beneficial mites: several cases have been reported on the occurrence of disease in mass cultures of predatory mites. In many instances, such observations have led to comprehensive studies on the mite pathogen involved.

Interest in pathogens of mites is increasing. This is apparent from literature reviews that have been published in recent years. We refer to reviews by Van der Geest (1985), McCoy (1996), Poinar and Poinar (1998), Samish and Řeháček (1999), Chandler et al. (2000) and Van der Geest, Elliot, Breeuwer, and Beerling (2000). A survey of pathogenic fungi infecting plant-inhabiting mites can be found in Van der Geest (2004). The student is referred to these reviews if more detailed information is required than is given in the underlying chapter.

Mites obtain their food in general by inserting their mouth parts into their vertebrate host or plant tissue. It is therefore unlikely that mites would contract disease through the alimentary tract unless the vertebrate host or food plant is infected by a pathogen. As penetration through the mouth parts is hampered, the pathogen should follow other infection routes. A plausible infection route is through the integument. Fungi are in general capable to penetrate a mite (or other arthropod species) through the integument. It is therefore not surprising that most mite pathogens are found among the fungi.

In this chapter, the different groups of microorganisms that may cause diseases in Acari will be treated.

\section{VIRUS DISEASES}

Relatively few viruses are known from mites, in strong contrast to what is observed in insects, from which more than 1,600 viruses have been described in about 1,100 species. Insect viruses are often embedded in larger inclusion bodies, as is the case for nuclear polyhedrosis viruses. The rod-shaped virus particles are situated in proteinaceous bodies that protect the virus against unfavorable conditions when released from the insect cadaver. Such structures are not found for viruses that are known from mites. Well-studied viruses in mites are found in two spider mite species: the citrus red mite, Panonychus citri, and the European red mite, P. ulmi.

The first record on a virus disease in a spider mite is by Muma (1955), who noted diseased mites in a natural population of the citrus red mite (CRM) in Florida, USA. Affected mites showed signs of diarrhea and the cadavers were adhered to the leaf surface by a black resinous material that was excreted from the anus. The disease has later also been reported in California by Smith, Hill, Munger, and 
Gilmore (1959). They observed spherical particles inside diseased mites and assumed that these were virus particles. Later, it could be demonstrated that a rodshaped, non-inclusion virus is the cause of the disease (Reed \& Hall, 1972). The virus particles are approximately $194 \times 58 \mathrm{~nm}$ in size and enclosed in an envelope of circa. $266 \times 111 \mathrm{~nm}$. The virus is formed inside the nuclei of epithelial cells of the midgut, but later it moves out of the nucleus, into the cytoplasm. The pathogen is transmitted when healthy mites ingest the feces of infected mites.

The spherical particles were studied in more detail by Reed and Desjardins (1978). These authors found spherical particles of three different sizes, but only in laboratory reared mites. The particles were apparently acquired by the mites from the green lemons on which they were grown. No detrimental effects of the particles on the mites were observed, although the spheres did multiply inside the mites. In diseased mites, birefringent bodies of irregular shape were found. The size of these bodies may vary from a few micrometers up to $50 \mu \mathrm{m}$ in diameter (Smith \& Cressman, 1962). The function of these bodies is not known, but they seem to be associated with the formation of the so-called fecal pellets, that probably contain guanine as excretion product. Similar bodies have been found in mites showing poor physiological condition (see Section 6.1).

The virus disease is common in citrus groves in California and Arizona and causes a considerable reduction in the population density of the CRM (Reed, 1981). In the 1960s, efforts were made to use the virus as a biological acaricide in order to control the CRM. A drawback in the use of viruses for biological control is that multiplication is only possible in living cells. Control experiments were carried out by spraying aqueous suspensions of macerated diseased mites (Shaw, Chambers, \& Tashiro, 1968). For this purpose, mites were grown on green lemons and harvested after infection. This is a very laborious method and can only be done for small field experiments. Another more efficient method was the collection of infected mites in the field by means of a vacuum-suction devise. The mites were subsequently kept on lemons for an additional 6-7 days in order to increase the level of infection. Application of field collected material usually rendered better results than virus suspensions obtained from laboratory cultured mites. The results in small field trials were promising, but large field applications were less satisfactory. Reasons are that the virus is easily inactivated by sunlight when applied as an aqueous suspension and that high temperatures have a negative effect on the virulence of the pathogen. An advantage of using viruses as biological control agent is that they have a narrow host spectrum: they are able to infect only a few species of spider mite and show no effect on other organisms, e.g. phytoseiids (Shaw, Moffitt, \& Sciven, 1967).

Steinhaus (1959) studied a virus disease of the European red mite (ERM) in California. He observed spherical particles with a size of 40-60 nm inside affected mites and assumed that these were virus particles. A virus disease was also observed in P. ulmi in fruit orchards in Ontario (Putman \& Herne, 1966). This disease was caused by a rod-shaped virus that developed inside the nuclei of fat body cells. There is no conclusive evidence that we are dealing with the same virus as the one that described from California. Affected mites can be recognized by a darker color of the immature stages, but diseased adults show no difference in color. The most conspicuous symptoms, however, is the presence of birefringent bodies inside the 
midgut of the mites. These crystal-like structures probably contain guanine. The virus may cause epizootics in natural populations, but only at high densities of the spider mite. Field experiments were carried out by Putman (1970) by introducing infected immature mites into a peach orchard. In this way, a considerable reduction of the mite population could be obtained. Sprays of aqueous suspensions of the virus were less successful. It was assumed that the leaves release virus inhibitors that inactivate the virus. Recent studies on virus diseases in tetranychids have not been conducted.

Transmission electron microscopy (TEM) has revealed virus-like particles in diseased females of the predatory mite Metaseiulus occidentalis (Poinar \& Poinar, 1998). Diseased females in laboratory colonies showed a reduced oviposition and often died suddenly with a paralyzed appearance (Hoy \& Jeyaprakash, 2008). Three types of icosahedral virus particles were detected by TEM analysis. One type was situated in epithelial cells, $47 \mathrm{~nm}$ in diameter with an electron dense core of $35 \mathrm{~nm}$. Poinar and Poinar (1998) assumed that these particles were similar to those reported earlier in the citrus red mite and also similar to those found in epithelial cells of diseased and healthy twospotted spider mites (see above). It might be possible that the predatory mites obtained these particles from their prey, T. urticae. A second type of virus particles in $M$. occidentalis was approximately $38 \mathrm{~nm}$ in diameter with an electron dense core of $20 \mathrm{~nm}$. These particles were located in large numbers in the nuclei of midgut cells, but free virions were also observed in the cytoplasm and lumen of the midgut. A third type of virus particles was $45 \mathrm{~nm}$ in diameter with a 35 $\mathrm{nm}$ dense core. These particles were only observed in tissue of the alimentary tract. We know little about the etiology of the disease and whether these observed particles are the cause of the disease and whether the predator becomes infected by feeding on infected prey. The predatory mites studied belonged to crowded laboratory colonies, no field material had been included in the study.

Virus-like particles have been observed in the yolk of eggs developing inside gravid Neoseiulus cucumeris by Steiner (1993) and inside Phytoseiulus persimilis females by Bjørnson, Steiner, \& Keddie (1997). In adults of these species, also birefringent crystals were observed, but there may be no relation between the presence of the virus-like particles and these crystals. Virus infections in cultures of predatory mites are undesirable as such conditions may affect the efficacy of the predator as biological control agent.

Several phytophagous species are known to transmit plant viruses. For example, the dry bulb mite Aceria tulipae has been reported as vector of two viruses of Allium sp. (Van Dijk \& Van der Vlugt, 1994) and Brevipalpus spp. are known as vector of, among others, citrus leprosis virus in citrus in Latin America (Rodrigues, Kitajima, Childers, \& Chagas, 2003), of orchid fleck virus in many orchid species world-wide (Kondo, Maeda, \& Tamada, 2003) and of coffee ringspot virus in coffee in Brazil and Costa Rica (Chagas, Kitajima, \& Rodrigues, 2003). It is doubtful whether these vector mites suffer from the presence of viruses inside their body, although the high plain virus and Pigeon Pea Mosaic virus seem to replicate in their respective vectors (Kumar, Duncan, Robert, Jones, \& Reddy, 2002). The Brome Mosaic Virus, usually transmitted by a beetle, is capable to multiply in the eriophyid Aceria tulipae. It may cause severe cytopathological effects in the midgut cells of the mite (Paliwal, 1972). Similarly, mites e.g. Dermanyssoidea play a role in the transmission of viruses to vertebrates (e.g. equine encephalitis viruses, West Nile virus, fowl pox virus) (Valiente Moro, Chauve, \& 
Zenner, 2005). It is not within the scope of this article to describe these viruses comprehensively, as they are considered to be plant, resp. vertebrate viruses.

Several viruses are known from the honeybee (Apis mellifera), some of which are associated with the varroa mite Varroa jacobsoni and the honeybee tracheal mite (HBTM) Acarapis woodi (Sammataro, Gerson, \& Needham 2000). These viruses may always be present in the bee, either in a latent or in an unapparent form. Wounds inflicted by the mites may activate the viruses in the bee. These viruses are probably not capable to infect the varroa mite or the HBTM, but the presence of these mites affects the incidence of virus disease in honey bees. The varroa mite may also play a role in the transmission of Bee Kashmir Virus (KBV), although the virus was already known from bee colonies before Apis mellifera colonies were infested by $V$. destructor. The presence of the virus in the mite has been demonstrated by several authors (e.g. Chen, Pettis, Evans, Kramer, \& Feldlaufer, 2004). Virus-free mites may become infected by coinhabiting in the same cell as virus-infected mites. Whether transmission to honey bees occurs mechanically or biologically is a question that has not yet been conclusively solved. Shen, Yang, Cox-Foster, and Cui (2005) suggested that varroa mites cause suppression of the immune system of the honey been which leads to activation of latent virus infections.

Liu (1991) found virus-like particles in a sample of HBTM that originated from Scotland, but no such particles were found in HBTM samples from California. Tissues of affected mites showed extensive lysis, while most cells were tightly packed with virus-like particles. The virions are $27-30 \mathrm{~nm}$ in size and are arranged in paracrystalline arrays forming hexagonal patterns. The ultrastructural morphology of the particles indicates that we may be dealing with a picorna-like virus. Such viruses resemble picornaviruses that are found in vertebrates. Picorna-like viruses are also known from honeybees, but on the basis of histopathological studies it was assumed that the virus found in HBTM is not derived from honeybees, but actually multiplies inside the mite.

Kleespies, Radtke, and Bienefield (2000) performed a search for diseases in varroa mites in parasitized bee colonies. They found mites with characteristic internal black-colored changes of the gut and the fat body. On living adult bees, $3.6 \%$ of the mites showed this anomaly, in brood cells, even $8 \%$ of the juvenile mites were affected. Disease incidence and intensity of the symptoms can be enhanced by changes in environmental conditions, such as deficiency of bee brood, deficiency of pollen, abnormal brood temperature and death of the host. The authors found that longevity of black-colored mites was reduced by $43 \%$. Cytopathological studies showed the presence of a large number of spherical virus-like particles, especially in the nuclei of fatbody and muscle tissue. The particles measure approximately $27-60 \mathrm{~nm}$ in diameter and were very similar to the particles found by Liu (1991) in HBTM. Per os infection experiments with extracts of fatbody tissue derived from symptomatic mites were unsuccessful.

Ongus et al. (2004) detected virus-like particles in varroa mites that were collected in bee hives in The Netherlands. The virions were mainly present in the cytoplasm of mite tissue and resemble the virus-like particles found by Kleespies et al. (2000). Immunochemical studies revealed that the virus was localized in the abdominal part of the alimentary tract and in the gastric caeca, but not in the salivary 
glands (Ongus, 2006). It was possible to isolate the virus and to determine the base sequence of the virus genome. The virus (Varroa destructor virus 1) is a single stranded RNA genome and, based on the base sequence, it was decided that it belongs to the genus Iflavirus (Ongus et al., 2004). Viruses in this genus belong also to the picorna-like viruses. The virus is closely related to deformed wing virus, known from honey bees. The latter virus causes morphological anomalies in wings of bees.

\section{DISEASES CAUSED BY BACTERIA}

The most widely studied bacterium in invertebrate pathology is Bacillus thuringiensis. It was first described in 1915 by Berliner, who isolated it from soil samples in the Thuringian Forest in Germany. Simultaneously with spore formation, a crystalline body is formed in the bacterium. Upon ingestion by an insect, this crystal ( $\delta$-endotoxin) falls apart into toxic subunits that may cause paralysis of the alimentary tract, resulting in the death of the insect. Most varieties (serotypes) of $B$. thuringiensis show an effect on larvae of Lepidoptera, but some also on other groups of insects, e.g. Coleoptera and Diptera.

Very comprehensive research has been carried out on B. thuringiensis that has resulted in the development of several commercial preparations that are mainly used against lepidopterous pests. Also, the gene encoding for the crystalline toxic body has been isolated and transferred into crop plants, e.g. corn and cotton, making these crops resistant towards a number of lepidopterous pests. Several serotypes of $B$. thuringiensis produce in addition an exotoxin, the $\beta$-exotoxin, named thuringiensin. This exotoxin is excreted by the bacterium into the culture medium. It has a nucleotide-like structure and inhibits DNA-dependent RNA polymerase. This results in a blockage of mitosis. When thuringiensin is applied to young holometabolous insects, morphological deformations may occur in the adult stage.

Field applications of thuringiensin were successful against the citrus red mite $P$. citri (Hall, Hunter, \& Arakawa, 1971) and Tetranychus pacificus (Hoy \& Ouyang, 1987). Later, Royalty, Hall, and Taylor (1990) conducted experiments by testing two different formulations of thuringiensin against the twospotted spider mite T. urticae. The results indicated that thuringiensin might be a potential acaricide. In particular young instars are susceptible, since these have a high growth rate. Various physiological processes in young organisms require higher RNA synthesis than in the older slower growing stages. A major drawback is that thuringiensin is toxic for a wide range of organisms. Not only are spider mites affected, but also beneficial mites, such as Phytoseiulus persimilis: oviposition starts to decline after 2 days and ceases completely after 3-4 days in both predator and spider mite T. urticae (Guo, Zuo, Zhao, Wang, \& Jiang, 1993). The chemical is apparently a nonselective acaricide that should not be used in combination with predatory mites.

The spore-crystal complex of $B$. thuringiensis has been tested on spider mites by Krieg (1972), but no mortality was observed. However, Chapman and Hoy (1991) conducted experiments in which T. urticae and Metaseiulus occidentalis were treated with a commercial preparation of $B$. thuringiensis var. tenebrionis. This variety of $B$. thuringiensis shows an effect on beetles and is recommended for use against the Colorado Potato Beetle, Leptinotarsa decemlineata. No effect was noted 
on the twospotted spider mite, but the preparation did show a toxic effect on $M$. occidentalis. Eggs were not affected, but if juveniles were treated, only $65 \%$ reached the adult stage. This toxic effect could be enhanced by starving the mites: the authors assumed that starvation may lead to a higher uptake of the material, or that the mites were more exposed to the preparation as starving mites tend to move faster. It is also possible that starvation acts as a stress factor. The authors have no explanation for the toxic effect on the predatory mite: the preparation did not contain the $\beta$-exotoxin (thuringiensin) known to be toxic for mites.

In more recent years, isolates of $B$. thuringiensis have been found that do show toxicity towards spider mites and house dust mites (Payne, Cannon, \& Bagley, 1993; Payne, Cannon, \& Ralph, 1994). It has been suggested to isolate the $\delta$-endotoxin of these isolates and to formulate it as an acaricide. One may also transfer the gene, encoding for this specific $\delta$-endotoxin into a crop plant in order to protect the crop against spider mite infestations.

An interesting discovery is the isolation of a $B$. thuringiensis strain from dead twospotted spider mites, T. urticae (Jung, Mizuki, Akao, \& Côte, 2007). In sporulating cultures of the bacterium, roughly spherical parasporal inclusion bodies are formed. This crystalline body is composed of at least two polypeptides of 86 and $79 \mathrm{KDa}$. The crystal is not toxic to the twospotted spider mite, but after cleavage with trypsin, it is cytocidal to some human cancer cells.

In Table 1, a list is given of bacteria that have been isolated from mites. We realize that this list may not be complete, but we have tried to limit the list to bacteria that show pathogenicity towards mites. Many species of bacteria may be isolated from mites (and other organisms): in many instances, these may not appear to be pathogenic.

Aksoy, Ozman-Sullival, Ocal, Celik, and Sullivan (2008) studied the effect of Pseudomonas putida biotype B on the twospotted spider mite T. urticae. The bacterium had been isolated from greenhouse soil in Turkey and was tested on newly emerged, copulated females. The authors observed a strongly reduced egg production and no hatching of the eggs was noted. The results showed that the bacterium may be very effective in causing mortality in T. urticae populations. Further research is required to find out whether this organism may be developed to a microbial miticide.

The predatory mite Phytoseiulus persimilis has been mass cultured for several decades for the biological control of spider mites in various field and glasshouse crops. This predator species is very important in integrated pest control programs and has stimulated research on predator-prey interactions and foraging behavior. It has been shown in several instances that adult female predatory mites are attracted to volatiles that are emitted by plants infested by prey. This emission of volatiles by the plant after herbivore attack is apparently a defense mechanism against herbivorous mites. Schütte (2006) noticed a change in response to prey-induced plant volatiles in a laboratory colony of $P$. persimilis. This population showed a lower attraction to these volatiles than other populations of the predator. It could be demonstrated that the change in behavior is caused by the involvement of a bacterium. Transmission of the bacterium occurs through feces and debris. There is no evidence that vertical transmission (from one generation to the next) occurs. The bacterium could be isolated and was described as Acaricomes phytoseiuli (Pukall, Schumann, Schütte, Gols, \& Dicke, 2006). Comparative analysis of the $16 \mathrm{~S}$ rDNA sequence revealed that it belongs to the Micrococcaceae, and that it is 
related to the soil bacterium Arthrobacter globiformis, to A. rissicus, a bacterium originally isolated from air in the Russian space laboratory and to Renibacterium salmoninarum, the causal agent of kidney disease in salmon. The bacterium clearly affects the effectiveness of $P$. persimilis as biological control agent as infected mites show a lower response to the volatiles emitted by the plant after herbivorous attack. At this moment, there are no signs that the disease is present in commercial populations of $P$. persimilis, nor is it widespread in laboratory populations of this predator.

Table 1. Bacterial infections in mites.

\begin{tabular}{|c|c|c|c|}
\hline Species & Mite host & Mite family & References \\
\hline $\begin{array}{l}\text { Bacillus } \\
\text { thuringiensis }\end{array}$ & $\begin{array}{l}\text { Spider mites } \\
\text { House dust mites }\end{array}$ & $\begin{array}{l}\text { Tetranychidae } \\
\text { Pyroglyphidae }\end{array}$ & Payne et al. $(1993,1994)$ \\
\hline B. thuringiensis & Tetranychus urticae & Tetranychidae & Jung et al. (2007) \\
\hline $\begin{array}{l}\text { B. thuringiensis } \\
\text { var. israelensis }\end{array}$ & $\begin{array}{l}\text { Dermatophagoides } \\
\text { pteronyssinus }\end{array}$ & Pyroglyphidae & Saleh et al. (1991) \\
\hline $\begin{array}{l}\text { B. thuringiensis } \\
\text { var. tenebrionis }\end{array}$ & Metaseiulus occidentalis & Phytoseiidae & Chapman and Hoy (1991) \\
\hline B. sphaericus & $\begin{array}{l}\text { Dermatophagoides } \\
\text { pteronyssinus }\end{array}$ & Pyroglyphidae & $\begin{array}{l}\text { Saleh, Kelada and Shader } \\
\text { (1991) }\end{array}$ \\
\hline Bacteroidetes & Metaseiulus occidentalis & Phytoseiidae & Hoy and Jeyaprakash (2008) \\
\hline Enterobacter & Metaseiulus occidentalis & Phytoseiidae & Hoy and Jeyaprakash (2008) \\
\hline $\begin{array}{l}\text { Pseudomonas } \\
\text { putida }\end{array}$ & Tetranychus urticae & Tetranychidae & Aksoy et al. (2008) \\
\hline $\begin{array}{l}\text { Acaricomes } \\
\text { phytoseiuli }\end{array}$ & Phytoseiulus persimilis & Phytoseiidae & Pukall et al. (2006). \\
\hline \multirow[t]{2}{*}{ Rickettsia sp. } & Metaseiulus occidentalis & Phytoseiidae & Hess and Hoy (1982) \\
\hline & Vatacarus ipoides & Trombiculidae & Thomas and Poinar (1973) \\
\hline $\begin{array}{c}\text { Rickettsiella } \\
\text { phytoseiuli }\end{array}$ & Phytoseiulus persimilis & Phytoseiidae & Šut’áková (1988) \\
\hline \multirow[t]{5}{*}{ Wolbachia } & Bryobia sp. & Tetranychidae & $\begin{array}{l}\text { Weeks (personal } \\
\text { communication) }\end{array}$ \\
\hline & Eutetranychus orientalis & Tetranychidae & Breeuwer and Jacobs (1996) \\
\hline & Oligonychus biharensis & Tetranychidae & Breeuwer and Jacobs (1996) \\
\hline & Tetranychus yusti & Tetranychidae & Breeuwer and Jacobs (1996) \\
\hline & Tetranychus kanzawai & Tetranychidae & $\begin{array}{l}\text { Breeuwer and Jacobs (1996) } \\
\text { Gomi, Gotoh, and Noda (1997) }\end{array}$ \\
\hline
\end{tabular}




\begin{tabular}{|c|c|c|c|}
\hline & $\begin{array}{l}\text { Tetranychus } \\
\text { neocaledonicus }\end{array}$ & Tetranychidae & Breeuwer and Jacobs (1996) \\
\hline & Tetranychus turkestani & Tetranychidae & Breeuwer and Jacobs (1996) \\
\hline & Tetranychus quercivorus & Tetranychidae & $\begin{array}{l}\text { Gotoh, Abe, Kurihara, and } \\
\text { Suzuki (1995) }\end{array}$ \\
\hline & Tetranychus urticae & Tetranychidae & $\begin{array}{l}\text { Breeuwer and Jacobs (1996) } \\
\text { Tsagkarakou, Guillemaud, } \\
\text { Rousset, and Navajas (1996) }\end{array}$ \\
\hline & Metaseiulus occidentalis & Phytoseiidae & $\begin{array}{l}\text { Johanowicz and Hoy (1966) } \\
\text { Breeuwer and Jacobs (1996) }\end{array}$ \\
\hline & Neoseiulus barkeri & Phytoseiidae & Breeuwer and Jacobs (1996) \\
\hline & Neoseiulus bibens & Phytoseiidae & Breeuwer and Jacobs (1996) \\
\hline & Phytoseiulus persimilis & Phytoseiidae & $\begin{array}{l}\text { Steiner (1993) and Breeuwer } \\
\text { and Jacobs (1996) }\end{array}$ \\
\hline \multirow[t]{3}{*}{ Cardinium sp. } & Brevipalpus phoenici & Tenuipalpidae & Groot and Breeuwer (2006) \\
\hline & Brevipalpus californicus & Tenuipalpidae & Chigira and Miura (2005) \\
\hline & $\begin{array}{l}\text { Euseius finlandicus } \\
\text { Neoseiulus californicus } \\
\text { Metaseiulus occidentalis }\end{array}$ & Phytoseiidae & $\begin{array}{l}\text { Enigi and Schausberger } \\
\text { (2007) Hoy and Jeyaprakash } \\
(2008)\end{array}$ \\
\hline Spiroplasma & $\begin{array}{l}\text { Tetranychus urticae } \\
\text { Dermanyssus gallinae }\end{array}$ & $\begin{array}{l}\text { Tetranychidae } \\
\text { Dermanyssidae }\end{array}$ & $\begin{array}{l}\text { Enigi and Schausberger (2007), } \\
\text { De Luna, Valente Moro, Guy, } \\
\text { Zenner, and Sparagano (2009) }\end{array}$ \\
\hline $\begin{array}{l}\text { Serratia } \\
\text { marcescens }\end{array}$ & Metaseiulus occidentalis & Phytoseiidae & $\begin{array}{l}\text { Lighthart, Sewall, and } \\
\text { Thomas (1988) }\end{array}$ \\
\hline
\end{tabular}

Mite and also tick species are frequently infected with intra-cellular microorganisms (Šut'áková, 1988, 1994; Steiner, 1993; Munderloh \& Kurtti, 1995; Bjørnson et al., 1997) These microorganisms have been placed into the family Rickettsiaceae within the class $\alpha$-Proteobacteria. The family Rickettsiaceae (or Rickettsia-like organisms) consists of three tribes: Rickettsieae, Ehrlichieae and Wolbachieae (Weiss \& Moulder, 1984). Representatives of these tribes have a number of features in common: they are obligate intracellular gram-negative bacteria naturally found in arthropod hosts, they multiply inside eukaryotic cells and are often surrounded by multiple membranes. Some are also capable of infecting humans and other vertebrates and are frequently pathogenic in these secondary hosts They often cause severe diseases such as spotted fever, typhus and scrub typhus (Hayes \& Burgdorfer, 1989). A good classification of these organisms has been hampered by the fact that classical microbiological identification tools cannot be used because of their 
obligate intracellular lifestyle. Since a number of years, tools have become available to sequence DNA of organisms. Sequence information on 16S rDNA genes has revealed interesting aspects of the order Rickettsiales, including their phylogeny. For additional information see Van der Geest et al. (2000).

The best studied group of rickettsia are those that are vectored by ticks, as they often cause disease in vertebrates and are therefore of great medical and veterinary importance. In plant-inhabiting mites, rickettsia-like infections have mainly been observed in microscopic surveys (Šut’áková, 1988, 1994; Hess \& Hoy, 1982; Steiner, 1993; Munderloh \& Kurtti, 1995; Bjørnson et al., 1997). They are described as intracellular microbes often localized in the reproductive tissue of their host, but no data are available on their possible effect on mites.

Hess and Hoy (1982) studied diseased laboratory colonies of the predatory mite Metaseiulus occidentalis more comprehensively, as these colonies produced only few eggs and often died out. Two different pathologies could be discerned. Some adult females were plump in appearance and had cream- to pink-colored plugs excreting from their rectum. Such females rarely produced eggs, although they appeared gravid. Immatures and males seldom showed this plug. The second condition affected both females and juveniles. These females failed to lay eggs and immatures often died, in particular during molting. Two forms of Rickettsia-like organisms were described, based on structure of the cell wall and the presence of cytoplasmic inclusions. Type A was observed in all mites examined, while type B was present in approximately two-thirds of the mites investigated. The Type A organisms were small, ovoid and $0.75 \mu \mathrm{m}$ in length and $0.5 \mu \mathrm{m}$ in width, with a trilaminar membrane of $7 \mathrm{~nm}$ thick, while Type B was rod-shaped, and measured 0.5 $\mu \mathrm{m}$ in width and $2 \mu \mathrm{m}$ in length. The Type A organisms were located intracellularly, singly or in groups of two or three in all tissues except ovarian and nervous tissue. The Type B organisms were both inter-and extracellular within membrane-bound vacuoles of cells that are similar in structure to mycetomes in insects. For a more detailed description is referred to Hoy and Jeyaprakash (2008).

Since the mid-1990s, molecular screening for intracellular microorganisms is possible. This has resulted in the discovery of Wolbachia in tetranychid and phytoseiid mites (e.g. Gotoh et al. 1995; Gotoh, Gomi, \& Nagata, 1999; Gotoh, Sugasawa, \& Nagata, 1999; Breeuwer \& Jacobs, 1996; Johanowicz \& Hoy, 1996; Tsagkarakou et al., 1996). Probably all Rickettsia-like organisms that have been reported in the early microscopic surveys are members of the genus Wolbachia belonging to the family Rickettsiaceae. These bacteria are parasites of the reproductive system of mites and insects and cause many unusual effects in their hosts, such as parthenogenesis (infected females produce only females), male killing (male embryos die while female embryos develop into adults), feminization (infected male embryo's develop into females) and cytoplasmic incompatibility.

Wolbachia is a bacterium that is vertically transmitted to the next generation through the females. It modifies host reproduction in several ways in order to enhance its own spread (Weeks \& Breeuwer, 2001). It induces parthenogenesis in the spider mite Bryobia praetiosa, causing males not to be produced. This is to the advantage of the bacterium, as only females are able to transmit the pathogen to the 
next generation. Probably over 1 million species of insects are infected, and infection rates in other taxa of arthropods may be similar.

Van Opijnen and Breeuwer (1999) showed that Wolbachia can induce cytoplasmic incompatibility in the arrhenotokous ${ }^{1}$ twospotted spider mite Tetranychus urticae between uninfected females and infected males. Cytoplasmic incompatibility is expressed through a male-biased sex ratio and low hatchability of eggs. It could be suppressed by removing Wolbachia from spider mites reared on a diet with antibiotics. The authors also demonstrated that heat treatment $\left(32^{\circ} \mathrm{C}\right.$.) can eliminate Wolbachia from infected mites. It was shown that $71 \%$ of the mites were "cured" after being reared for four generations at $32^{\circ} \mathrm{C}$. The infection could be completely eliminated by keeping the mites for 6 generations at $32^{\circ} \mathrm{C}$.

In a recent study Hoy and Jeyaprakash (2008) studied M. occidentalis females with large anal plugs. These females were collected from crowded laboratory colonies. The authors used 16S PCR primers to amplify the bacterial DNA and subsequently cloned and sequenced the products. It was remarkable that only bacteria were found that could also be detected in "healthy" females, viz. Wolbachia, Cardinium, an undescribed species of Bacteroidetes and an Enterobacter species. The authors assumed that stress could increase the titer of one or more endosymbionts which may lead to "disease". The authors cite the statement of Dale and Moran (2006) that "as more cases of chronic bacterial infection are characterized, the distinction between pathogenesis and mutualism has become increasingly blurred. Infection by a particular bacterium may be beneficial to a host under circumstances but harmful in other hosts or environments" Another interpretation for the occurrence of the disease in M. occidentalis is that the predator obtains Rickettsia-like organisms from its food. Rickettsia-like organisms have been detected in twospotted spider mites. However, there is no conclusive evidence that the predator obtains the endosymbionts from its prey (Hoy \& Jeyaprakash, 2008).

Groot and Breeuwer (2006) showed the presence of the symbiont Cardinium in the thelytokous ${ }^{2}$ mite species Brevipalpus phoenici. Cardinium spp. belong to the Flexibacteraceae (Phylum: Bacteroidetes; Class: Sphingobacteria). It was demonstrated that Cardinium induces thelytoky by feminizing unfertilized haploid eggs. Isofemale lines were set up and in some of these lines, males were produced by only very young daughters, while older females produce daughters exclusively. That a bacterium was involved was apparent from the fact that a treatment with antibiotics resulted in an increased number of male progeny. The presence of Cardinium was also shown in B. californicus (Chigira \& Miura, 2005). Tetracyclinetreated females produced many male progeny while untreated females produced only female progeny. This is an indication that B. californicus is feminized by Cardinium. Comparison of infected females with uninfected males and other closely related species, revealed that Cardinium does not have a negative effect on the fitness of B. californicus. The bacterium has also been found in a population of

\footnotetext{
${ }^{1}$ Arrhenotokous: capable of producing male offspring only.

${ }^{2}$ Thelytokous: capable of producing female offspring only.
} 
Eotetranychus suginamensis in Japan (Gotoh, Noda, \& Ito, 2006). One species of spider mite, Eotetranychus pueraricola harbored both Cardinium and Wolbachia, but these symbionts seemed to have no effect on the reproduction of the host. Cardinium has also been found to play a role in insect species, e.g. Encarsia sp. Cardinium is also present in field populations of the predatory mites Euseius finlandicus and Neoseiulus californicus and the spider mite Eotetranychus uncatus (Enigi \& Schausberger, 2007). The endosymbionts has also been detected in the poultry red mite Dermanyssus gallinae (De Luna et al., 2009).

Another genus of endosymbionts is the genus Spiroplasma. This genus belongs to the family Spiroplasmataceae, class Mollicutes, phylum Firmicutes. These bacteria are fastidious organisms which means that they can only been grown on rich nutrient media. Spiroplasma has been shown to kill males of Danaus chrysippus (Lepidoptera) and also of other insect species. Interspecific transmission of Spiroplasma poulsonii, a male-killing symbiont has been demonstrated between Drosophila sp. and Macrocheles sp., an ectoparasitic mite that feeds on the hemolymph of Drosophila (Jaeniki, Polak, Fiskin, Helou, \& Minhas, 2007). Enigi and Schausberger (2007) showed the presence of Spiroplasma in the twospotted spider mite, but its effect on reproduction and other biological parameters is not yet known. Spiroplasma has also been detected in the poultry red mite Dermanyssus gallinae (De Luna et al., 2009).

The ecological implications of modification of reproduction in herbivorous and predatory mites by intracellular symbionts is an interesting field of study. It will be clear that such modifications will have a great impact on the development of mite populations.

\section{DISEASES CAUSED BY FUNGI}

The Kingdom Fungi is a monophyletic assemblage which comprises at present four phyla: Chytridiomycota, Zygomycota, Basidiomycota and Ascomycota. In addition, there is a group called the Deuteromycetes (or Fungi Imperfecti), fungi of which no sexual stage is known. In the past, many parasitic fungi were classified in this group, but were reclassified after the sexual stage had been discovered. Most of these "reclassified" fungi belong to the Ascomycota. Nucleotide sequence analysis also suggests that the majority of these fungi belong to the Ascomycota. A large number of fungi capable to infect arthropods are found in the Deuteromycetes.

Chytridiomycota and Zygomycota share common features, in particular the absence of cross walls (septa) in their hyphae. The Chytridiomycota (chytrids) represent a primitive group of aquatic fungi. Chytrids have gametes that are mobile by means of flagella. No chytrids are known that infect mites.

Zygomycota are characterized by the formation of zygospores. These sexual spores are not contained within a specialized fruiting body or sac, but are unenclosed (or naked) between their parental hyphae. The haploid nuclei at the end of two hyphae fuse to a diploid zygote. This zygote undergoes immediately meiosis to form haploid cells that develop into zygospores.

Ascomycota are also called "sac fungi" as their sexual spores (ascospores) are enclosed in tube-like sacs, known as asci. The formation of ascospores is similar to 
that of zygospores, but the spores are not naked but contained within asci. Ascomycota have cross walls in their hyphae.

Basidiomycota are also known as the "club fungi". Their sexual spores are formed on often very complex fruiting bodies called basidia. This group of fungi possesses also septa inside their hyphae.

\subsection{Zygomycota}

In this phylum, only the order Entomomophthorales (meaning insect destroyers) (class Zygomycetes) contains species that are pathogenic for Arthropoda. These fungi are mainly obligatory pathogens of insects and other arthropods, often with a restricted host spectrum. However, some species are parasitic on desmids (green algae) or fern prothalli while other species may be saprophytic on plant debris (Moore-Landecker, 1996). Hosts that are infected by fungi of this group are usually not killed before all available nutrients have been utilized, in contrast to, e.g. Deuteromycetes infections where mycotoxins often cause the death of the host prior to the complete utilization of food reserves. Hajek (1997) assumed that the complete utilization of the live host by the fungus seems to be consistent with the obligate nature of this group of fungi.

As mentioned above, Zygomycetes are characterized by their sexual reproduction, the so-called zygospore formation, usually inside the parasitized host. Zygospores bud laterally from conjugation bridges between gametangia ${ }^{3}$ (hyphal bodies). These thick-walled, dark-colored spores are also called resting spores and may germinate to produce conidiophores with conidia attached. Other types of resting spores are chlamydospores, thick-walled, nonsexual spores originating from transformed hyphal cells, and azygospores that may arise from parthenogenetic development of hyphal bodies (short segments of mycelium inside the host). Azygospores may also be the result of budding of chlamydospores, or they may be formed at the tip of hyphae that arise from chlamydospores or hyphal bodies. Resting spores (Fig. 1) seem to aid the fungus in surviving unfavorable conditions, e.g. periods of drought. Conditions under which resting spores germinate are not well-understood.

More common is the formation of sporangiospores or ballistospores. These asexual spores are nonmotile and are formed within a sac-like structure, the sporangiole. Under nearly saturated conditions, these spores (by most mycologists called: primary conidia) are forcibly discharged from the spore bearing structure (sporangiophore, conidiophore). Primary conidia are often sticky due to the presence of a mucous substance causing them to adhere to a substrate after they have been released. The conidia may either form hyphae directly that may infect a new host or form secondary conidia.

Six families are recognized within the Entomomophthorales; pathogens of arthropods are mainly found in the Entomophthoraceae, Neozygitaceae and Ancylistaceae. These families are recognized on the basis of nuclear characters (size,

\footnotetext{
${ }^{3} \mathrm{~A}$ single-celled structure producing gametes (sex cells) or gametic nuclei.
} 
number, stainability), mode of formation of resting spores, and mechanism of discharge of primary conidia.

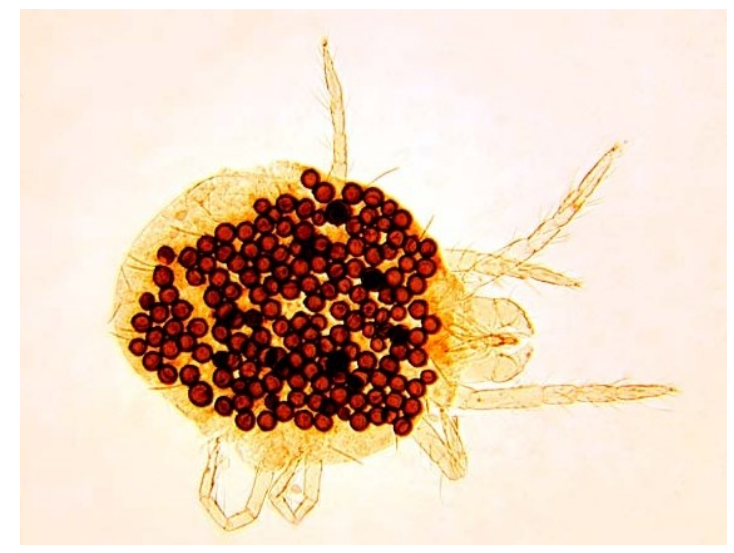

Figure 1. Resting spores of Neozygites tanajoae in the cassava green mite Mononychellus tanajoa. Photograph courtesy of Dr. Fabien C.C. Hountondji.

Entomophthoraceae are obligate pathogens of arthropods. In this family, primary conidia are released in a cannon-like manner when the conidiophore ruptures at the apex. The conidium is actually a bud at the apex of the conidiophore that is filled with protoplasm from the conidiophore. When the conidium is fully developed, both conidium and conidiophore absorb water quickly under humid conditions. The osmotic pressure is larger in the conidium than in the conidiophore and this fact results in the forcible discharge of the conidium. When the spore lands on a suitable host, it may infect the host after germination. These primary conidia may form secondary conidia if landed on a non suitable substrate. A well-known example is Entomophthora muscae, a species capable to infect flies. Mites infecting species are known in the genus Tarichium. Of species of this genus, only resting spores are known and species determination is largely based on the shape and size of the resting spores. Tarichium spp. have been isolated in soil samples from several species of mites, in many cases Oribatidae (e.g. Bałazy \& Wiśniewski, 1982, 1984).

Neozygitaceae are obligate pathogens of insects (mainly Homoptera) and mites. They release primary conidia that germinate to form smaller secondary conidia with an adhesive haptor on long, thin conidiophores. The resting spores are often dark-colored and ornamented on the outside wall. They possess two pores and are formed inside the hosts.

Ancylistaceae contains a number of representatives that may not only infect arthropods, but also vertebrates. For example, Conidiobolus coronatus causes serious infectious of mucous membranes of humans and other vertebrates (Maiti et al., 2004). Other species in this family are found in the soil and are often saprophytic. Primary conidia are forcibly discharged towards a light source and germinate to form secondary conidia that usually have the same shape as the primary conidia. The secondary conidia are either forcibly discharged or discharged passively from long slender conidiophores. 


\subsubsection{Course of Infection}

Entomophthoralean fungi usually penetrate their host through the cuticle by means of a germ tube that is formed by the conidium. Mite infecting species are mainly found in the Neozygitaceae. The primary conidium is released from the conidiophore and forms on top of a slender tube a much smaller secondary conidium, called capilliconidium. The capilliconidium is considered to be the infectious propagule. When landed on a suitable host, it penetrates through the cuticle by means of a newly formed germ tube (Fig. 2). After penetration, mycelium is formed within the body cavity of the host that fragments into a number of smaller segments, the hyphal bodies. Hyphal bodies are the propagative units and multiply by budding and by undergoing fission. In addition, rhizoids may be formed: sterile hyphae, often branched, that perforate the ventral side of the host and attach the host to the substrate. The infected host becomes in this way fixed to the substrate, also after its death. Favorable conditions (high relative humidity) allow the formation of conidiophores that grow through the cuticle of the host. On top of these structures, conidia are formed that form a halo around the dead host after discharge from the conidiophores. The spores have a mucous substance on the outside and stick to the substrate on which they have landed. They may be picked up by new, uninfected hosts. A high relative humidity (near saturation point) is required at two points in the course of the disease: germination of the spores needs a high relative humidity, but also sporulation requires humid conditions.

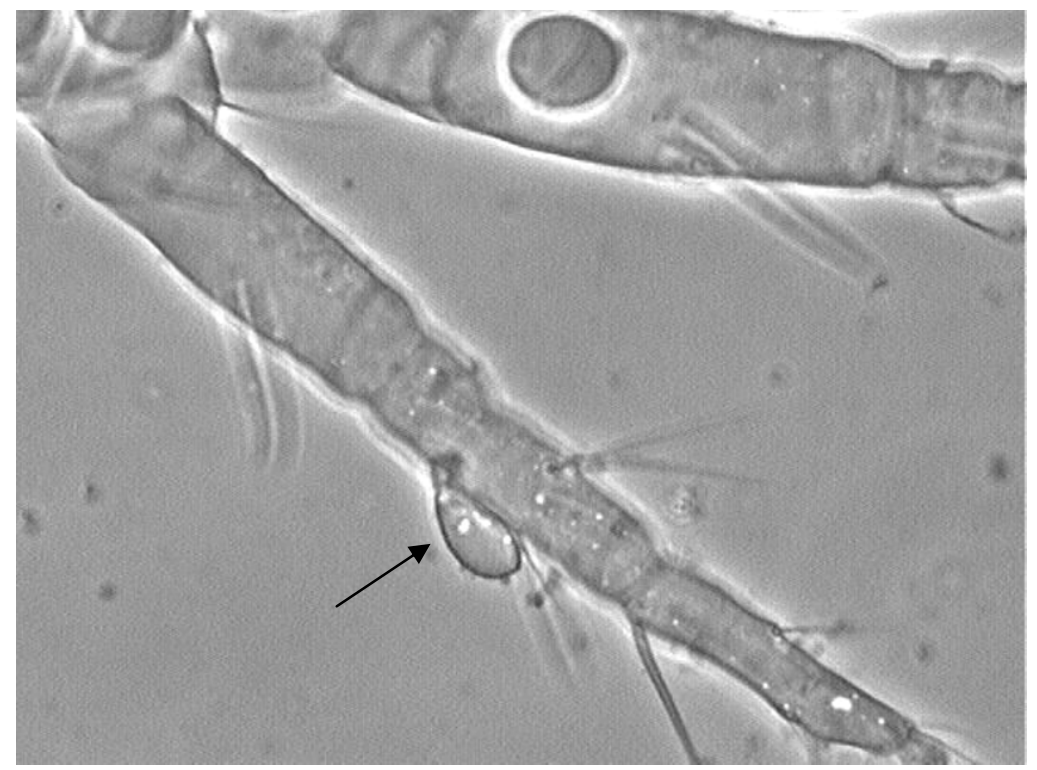

Figure 2. Capilliconidium of a Neozygites sp. on a leg of a spider mite Photograph: Leo P.S. van der Geest. 
The presence of rhizoids is an important property of the fungus for a successful transmission of the disease to a new host: the dead host (mummy) remains fixed to the plant surface and does not fall on the soil. In this way, chances for a successful transmission are increased.

The formation of resting spores is an interesting phenomenon. Sometimes, resting spores are present in large numbers. It is assumed that they may assist the fungus to overcome poor favorable conditions, such as extreme periods of drought. However, we still know very little about the role of resting spores and the conditions under which they germinate are poorly understood. The fungus may also survive unfavorable conditions in other manners. Klingen, Wærsted, and Westrum (2008) showed that Neozygites floridana may survive cold winter periods in the form of hyphal bodies inside hibernating females of T.urticae.

Most entomophthoralean fungi are difficult to culture in artificial culture media. For mass production, it is often necessary to use live host. Species that can be cultured in artificial media have usually a broad host spectrum. On the other hand, species with a restricted host range can hardly be grown outside their host, although some progress have been made with very complex culture media. Entomophthorales observed in mites are given in Table 2.

Table 2. Entomophthoralean fungi infecting mites and their hosts.

\begin{tabular}{|c|c|c|c|}
\hline Fungus species & Mite species & Mite family & References \\
\hline \multirow{4}{*}{$\begin{array}{l}\text { Not identified } \\
\text { Entomophthoralean } \\
\text { species }\end{array}$} & Arctoseius sp. & Arctoseiinae & $\begin{array}{l}\text { Bałazy and Wiśniewski } \\
\text { (1989) }\end{array}$ \\
\hline & $\begin{array}{l}\text { Macrocheles } \\
\text { peregrinus }\end{array}$ & Macrochelidae & Milner (1985) \\
\hline & $\begin{array}{l}\text { Pergamasus } \\
\text { crassipes }\end{array}$ & Parasitidae & Milner (1985) \\
\hline & $\begin{array}{l}\text { Tetranychus } \\
\text { desertorum }\end{array}$ & Tetranychidae & Walter (1999) \\
\hline \multirow{3}{*}{$\begin{array}{l}\text { Resting spores of } \\
\text { Entomophtoralean } \\
\text { species }\end{array}$} & Agistemus & Stigmaeidae & \multirow{3}{*}{$\begin{array}{l}\text { Van der Geest, De Moraes, } \\
\text { Navia, and Tanzini (2002) }\end{array}$} \\
\hline & Asca sp. & Ascidae & \\
\hline & $\begin{array}{l}\text { Amblyseius } \\
\text { igarassuensis }\end{array}$ & Phytoseiidae & \\
\hline Basidiobolus sp. & Tetranychus urticae & Tetranychidae & See: Chandler et al. (2000) \\
\hline Conidiobolus sp. & Bryobia sp. & Tetranychidae & $\begin{array}{l}\text { Bałazy, Mietkiewski, } \\
\text { Tkaczuk, Wegensteiner, } \\
\text { and Wrzosek (2008) }\end{array}$ \\
\hline $\begin{array}{c}\text { Conidiobolus } \\
\text { brefeldionis }\end{array}$ & $\begin{array}{l}\text { Tyrophagus } \\
\text { perniciosus }\end{array}$ & Acaridae & See: Chandler et al. (2000) \\
\hline $\begin{array}{l}\text { Conidiobolus } \\
\text { chapowski }\end{array}$ & Pergamasus & Parasitidae & See: Chandler et al. (2000) \\
\hline
\end{tabular}


Table 2 Continued

\begin{tabular}{|c|c|c|c|}
\hline $\begin{array}{l}\text { Conidiobolus } \\
\text { coronatus }\end{array}$ & Dendrolaelaps sp. & Digamasellidae & Bałazy et al. (2008) \\
\hline \multirow[t]{4}{*}{$\begin{array}{l}\text { Conidiobolus } \\
\text { obscurus }\end{array}$} & $\begin{array}{l}\text { Phytoseiulus } \\
\text { persimilis }\end{array}$ & Phytoseiidae & $\begin{array}{l}\text { See: Chandler et al. (2000) } \\
\text { Nyiira (1982) }\end{array}$ \\
\hline & $\begin{array}{l}\text { Mononychellus } \\
\text { tanajoa }\end{array}$ & Tetranychidae & \multirow{3}{*}{ See: Chandler et al. (2000) } \\
\hline & $\begin{array}{l}\text { Tetranychus } \\
\text { bimaculatus }\end{array}$ & & \\
\hline & Tetranychus urticae & & \\
\hline \multirow{10}{*}{$\begin{array}{r}\text { Conidiobolus } \\
\text { thromboides }\end{array}$} & Tetranychus urticae & \multirow[t]{9}{*}{ Tetranychidae } & See: Chandler et al. (2000) \\
\hline & Eotetranychus & & Selhime and Muma (1966) \\
\hline & $\begin{array}{l}\text { sexmaculaturs } \\
\text { Mononychellus sp. }\end{array}$ & & $\begin{array}{l}\text { Bartkowski Odindo, and } \\
\text { Otieno (1988) }\end{array}$ \\
\hline & $\begin{array}{l}\text { Mononychellus } \\
\text { tanajoa }\end{array}$ & & $\begin{array}{l}\text { Delalibera, Sosa Gomez, } \\
\text { De Moraes, De Alencar, } \\
\text { and Farias Araujo (1992) }\end{array}$ \\
\hline & Tetranychus evansi & & Fisher (1951) \\
\hline & $\begin{array}{l}\text { Tetranychus } \\
\text { pacificus }\end{array}$ & & $\begin{array}{l}\text { Humber, De Moraes, and } \\
\text { Dos Santos (1981) }\end{array}$ \\
\hline & Tetranychus & & Steinhaus and Marsh (1962) \\
\hline & tumidus & & See: Chandler et al. (2000) \\
\hline & $\begin{array}{l}\text { Tetranychus } \\
\text { turkestani }\end{array}$ & & $\begin{array}{l}\text { Carner and Canerday } \\
\text { (1968) }\end{array}$ \\
\hline & Vatacarus sp. & Trombiculidae & See: Chandler et al. (2000) \\
\hline $\begin{array}{l}\text { Erynia } \\
\text { phalangicidae }\end{array}$ & Pergamasus sp. & Parasitidae & $\begin{array}{l}\text { Bałazy and Wiśniewski } \\
\text { (1984) }\end{array}$ \\
\hline Zoophthora radicans & Tetranychus urtcae & Tetranychidae & See Chandler et al. (2000) \\
\hline \multirow[t]{2}{*}{ Neozygites sp. } & \multirow{2}{*}{$\begin{array}{l}\text { Euseius citrifolius } \\
\text { Alaskozetes } \\
\text { antarcticus }\end{array}$} & \multirow[t]{2}{*}{$\begin{array}{l}\text { Phytoseiidae } \\
\text { Ameronothridae }\end{array}$} & $\begin{array}{l}\text { Furtado, De Moraes, and } \\
\text { Keller (1996) }\end{array}$ \\
\hline & & & $\begin{array}{l}\text { Bridge and Worland (2004, } \\
\text { 2008) }\end{array}$ \\
\hline \multirow[t]{2}{*}{$\begin{array}{l}\text { Neozygites } \\
\text { abacaridis }\end{array}$} & \multirow{2}{*}{$\begin{array}{l}\text { Abacarus hystrix } \\
\text { Aculodes mckenziei } \\
\text { Aculodes sp. } \\
\text { Aculus fockeui }\end{array}$} & \multirow[t]{2}{*}{ Eriophyidae } & $\begin{array}{l}\text { Miętkiewski and Bałazy } \\
(2003)\end{array}$ \\
\hline & & & $\begin{array}{l}\text { Bałazy, Mietkiewski, } \\
\text { Tkaczuk, Wegensteiner, } \\
\text { and Wrzosek (2008) }\end{array}$ \\
\hline
\end{tabular}


Table 2 Continued

\begin{tabular}{|c|c|c|c|}
\hline \multirow[t]{2}{*}{ Neozygites acaricida } & $\begin{array}{l}\text { Halotydeus } \\
\text { destructor }\end{array}$ & Eupodidae & See Chandler et al. (2000) \\
\hline & Penthaleus major & Penthaleidae & \multirow[b]{2}{*}{ James (1994) } \\
\hline Neozygites acaridis & $\begin{array}{l}\text { Halotydeus } \\
\text { destructor } \\
\text { Penthaleus major }\end{array}$ & $\begin{array}{l}\text { Eupodidae } \\
\text { Penthaleidae }\end{array}$ & \\
\hline \multirow[t]{12}{*}{$\begin{array}{l}\text { Neozygites } \\
\text { floridana }\end{array}$} & \multirow{2}{*}{$\begin{array}{l}\text { Bryobia sp. } \\
\text { Eotetranychus } \\
\text { banksi }\end{array}$} & \multirow[t]{12}{*}{ Tetranychidae } & $\begin{array}{l}\text { Miętkiewski, Balazy, and Van } \\
\text { der Geest (1993) }\end{array}$ \\
\hline & & & Weiser and Muma (1966) \\
\hline & $\begin{array}{l}\text { Oligonychus } \\
\text { gossypii }\end{array}$ & & $\begin{array}{l}\text { Yaninek, Saizonou, Onzo, } \\
\text { Zannou, and Gnanvossou (1996) }\end{array}$ \\
\hline & \multirow[t]{3}{*}{$\begin{array}{l}\text { Oligonychus } \\
\text { hondoensis }\end{array}$} & & Nemoto and Aoki (1974) \\
\hline & & & $\begin{array}{l}\text { Dick, Buschman, and Ramoska } \\
\text { (1992) } \\
\text { Fisher (1951) }\end{array}$ \\
\hline & & & Rameseshiah (1971) \\
\hline & Oligonychus & & Saba (1971) \\
\hline & pratensis & & Smith and Furr (1975) \\
\hline & Panonychus citri & & \\
\hline & Tetranychus ludeni & & \\
\hline & Tetranychus tumidus & & \\
\hline & Tetranychus urticae & & \\
\hline \multirow[t]{2}{*}{$\begin{array}{l}\text { Neozygites } \\
\text { tanajoae }\end{array}$} & $\begin{array}{l}\text { Mononychellus } \\
\text { tanajoa }\end{array}$ & \multirow[t]{2}{*}{ Tetranychidae } & \multirow[t]{2}{*}{$\begin{array}{l}\text { Delalibera, Hajek, and Humber } \\
\text { (2004) }\end{array}$} \\
\hline & Oligonychus gossypii & & \\
\hline $\begin{array}{l}\text { Neozygites } \\
\text { tetranychid }\end{array}$ & Tetranychus urticae & Tetranychidae & Weiser (1968) \\
\hline $\begin{array}{l}\text { Tarichium } \\
\text { acaricolum }\end{array}$ & Pergamasus sp. & Parasitidae & Bałazy and Wiśniewski (1984) \\
\hline $\begin{array}{l}\text { Tarichium } \\
\text { azygosporicum }\end{array}$ & Pergamasus sp. & Parasitidae & $\begin{array}{l}\text { Bałazy, Wiśniewski, and } \\
\text { Kaczmarek (1987) }\end{array}$ \\
\hline $\begin{array}{l}\text { Tarichium } \\
\text { distinctum }\end{array}$ & Pergamasus sp. & Parasitidae & Bałazy et al. (1987) \\
\hline $\begin{array}{l}\text { Tarichium } \\
\text { hyalinum }\end{array}$ & $\begin{array}{l}\text { Tectocepheus } \\
\text { velatus }\end{array}$ & Parasitidae & Bałazy et al. (1987) \\
\hline $\begin{array}{l}\text { Tarichium } \\
\text { monokaryoticum }\end{array}$ & $\begin{array}{l}\text { Tricouropoda } \\
\text { szczecinensis }\end{array}$ & Uropodidae & Bałazy et al. (1987) \\
\hline
\end{tabular}


Table 2 Continued

\begin{tabular}{|c|c|c|c|}
\hline \multirow{4}{*}{$\begin{array}{l}\text { Tarichium } \\
\text { svalbardense }\end{array}$} & Dinychus carinatus & Prodinychidae & Bałazy et al. (1987) \\
\hline & \multirow{3}{*}{$\begin{array}{l}\text { Pergamasus sp. } \\
\text { Veigaia } \mathrm{sp} .\end{array}$} & Parasitidae & \multirow{2}{*}{$\begin{array}{l}\text { Bałazy and Wiśniewski } \\
\text { (1984) }\end{array}$} \\
\hline & & \multirow{2}{*}{ Veigaiidae } & \\
\hline & & & Bałazy et al., 1987 \\
\hline $\begin{array}{l}\text { Tarichium } \\
\text { obtusoangulatum }\end{array}$ & Uropoda minima & Uropodidae & $\begin{array}{l}\text { Bałazy and Wiśniewski } \\
\text { (1984) }\end{array}$ \\
\hline Tarichium pusillum & Pergamasus sp. & Parasitidae & $\begin{array}{l}\text { Bałazy and Wiśniewski } \\
\text { (1984) }\end{array}$ \\
\hline $\begin{array}{l}\text { Tarichium } \\
\text { sphaericum }\end{array}$ & $\begin{array}{l}\text { Trachyuropoda } \\
\text { coccinea }\end{array}$ & Trachyuropodidae & $\begin{array}{l}\text { Bałazy and Wiśniewski } \\
\text { (1984) }\end{array}$ \\
\hline \multirow{3}{*}{$\begin{array}{l}\text { Tarichium } \\
\text { subglobosum }\end{array}$} & \multirow{3}{*}{$\begin{array}{l}\text { Pergamasus sp. } \\
\text { Uropoda minima }\end{array}$} & \multirow{3}{*}{$\begin{array}{l}\text { Parasitidae } \\
\text { Uropodidae }\end{array}$} & Bałazy and Wiśniewski \\
\hline & & & (1984) \\
\hline & & & $\begin{array}{l}\text { Bałazy and Wiśniewski } \\
\text { (1984) }\end{array}$ \\
\hline $\begin{array}{l}\text { Tarichium } \\
\text { tenuisculpturatum }\end{array}$ & Pergamasus sp. & Parasitidae & $\begin{array}{l}\text { Bałazy and Wiśniewski } \\
\text { (1984) }\end{array}$ \\
\hline $\begin{array}{l}\text { Tarichium } \\
\text { uropodinis }\end{array}$ & $\begin{array}{l}\text { Trachyuropoda } \\
\text { coccinea }\end{array}$ & Trachyuropodidae & $\begin{array}{l}\text { Bałazy and Wiśniewski } \\
\text { (1982) }\end{array}$ \\
\hline \multirow{2}{*}{$\begin{array}{l}\text { Tarichium } \\
\text { verruculosum }\end{array}$} & Celaenopsis sp. & Celaenopsidae & \multirow[t]{2}{*}{ Bałazy et al. (1987) } \\
\hline & Unidentified & Galumnidae & \\
\hline
\end{tabular}

\subsubsection{Natural Entomophthoraceous Infections}

The first record of an entomophthoralean fungus infection in spider mites was observed by Fisher (1951) who noted adult mortality from 32 to $95 \%$ in populations of the citrus red mite Panonychus citri. The fungus was in particular prevalent during late summer and early autumn throughout the Florida peninsula. Weiser and Muma (1966) isolated the fungus later from the Texas citrus mite Eutetranychus banksi and described it as Entomophthora floridana. The fungus has since been reported from several other spider mites species: For example, it was observed in Tetranychus tumidis on cotton in the humid subtropical regions of Florida (Saba, 1971), in T. evansi on tomato crops in Brazil (Humber et al., 1981), in T. ludeni on bean in India (Ramaseshiah, 1971), in Oligonychus hondoensis on cedar in Japan (Nemoto \& Aoki, 1975) and in T. urticae on field corn in North Carolina, USA (Brandenburg \& Kennedy, 1982). The fungus has also been reported in Poland on the twospotted spider mite T. urticae and on Bryobia sp. (Miețkiewski et al., 1993).

Keller and Wuest (1983) noted infections by Neozygites adjarica in T. urticae on bean in Switzerland, but later investigations showed that this fungus is identical to N. floridana; N. tetranychi, described by Weiser (1968) as a pathogen of the 
twospotted spider mite from a fruit orchard in Southern Bohemia, Czech Republic, is also considered to be a synonym of $N$. floridana (Keller, 1997).

Bridge and Worland (2008) observed a Neozygites infection in the cryprostigmatic mite Alaskozetes antarcticus (Ameronothridae). This mite was collected at Rip Point, Nelson Island off the West coast of the Antarctic peninsula. A few specimens appeared to be infected by a fungus that was provisionally described as Neozygites cf. acaridis. The mite survives the harsh climatic conditions by lowering the freezing point by the accumulation of low molecular weight cryoprotective compounds such as glycerol, together with the removal or masking of ice-nucleating substances from its body.

The introduction of the cassava green mite Mononychellus tanajoa into the cassava growing regions on the African continent has led to a comprehensive search for natural enemies of this pest. This has resulted in the isolation of a Neozygites sp. that is very specific for the cassava green mite in Venezuela by Agudela-Silva (1986) and later also in Brazil by Delalibera et al. (1992). The fungus is also known from the African continent. Originally, the fungus was considered to be identical to $N$. floridana, although it did show differences in, among others, its very restricted host spectrum and in the size of the conidia. Recently, the fungus has been described as $N$. tanajoae (Delalibera et al., 2004). It can be distinguished from $N$. floridana on the basis of $18 \mathrm{~S}$ ribosomal DNA (rDNA) sequences, host range, nutritional requirement for growth in vitro, tolerances to low temperatures $\left(4^{\circ} \mathrm{C}\right)$ and ability to withstand specific cryopreservation techniques. $N$. tanajoae isolates from Brazil and Africa have identical 18S rDNA sequences but they presented 5.7 and $9.94 \%$ pair wise distance from $N$. floridana isolates. $N$. tanajoae proved to differ sufficiently from other mitepathogenic fungi referred to as $N$. floridana to justify the description as a new species.

\subsubsection{Role of Neozygites floridana in the Field}

The role of Neozygites spp. in the field has been studied in a number of instances. Numerous examples show that Neozygites sp. may have a major impact on populations of spider mites in agricultural crops. Saba (1971) observed Neozygites floridana in populations of T. tumidus in cotton field in the humid subtropical part of Florida. A reduction of 220 spider mites per cotton leaf down to less than 1 spider mite was noted during a period of warm humid weather with heavy rainfall. This reduction could be mainly attributed to the presence of the fungus disease. Similar observations were made by others, e.g. Smith and Furr (1975) who established that Neozygites in the main factor that limits late-season population increases of $T$. urticae on cotton in the delta of the Mississippi and Carner (1976) who found the fungus throughout the states Georgia, South Carolina and Alabama. He considered Neozygites a very important factor in regulating spider mite populations in cotton.

Treatment of crops with fungicides may affect the incidence of fungus disease in populations of spider mite: Brandenburg and Kennedy (1983) observed a lower proportion of spider mites infected by Neozygites in lima beans when the fungicide benomyl was applied. The fungicide did not affect sporulation of the pathogen, but seemed to have an effect on conidial germination and growth of the fungus. 
Immature stages of $T$. urticae are more susceptible to $N$. floridana than adult mites, while adult females are more susceptible to infection than adult males (Susilo Nordin, \& Brown, 1994). The authors suggest than the thinner cuticle of the immature mites could be the cause that immature stages are more vulnerable to the fungus disease. That males are less susceptible to infection is probably due to the stronger cuticle of this sex compared to that of females. Males have to compete with other males for females which may have resulted in a tougher cuticle. On the other hand, females have a more elastic opisthosomal cuticle, needed for ovarial development and oviposition. The authors speculate that the cuticle of females might be thinner, or somewhat different in chemical composition.

Infection by entomogenous fungi results from penetration of the fungus through the cuticle of the host by a combination of enzymatic and mechanical processes. Successful infection by a fungus depends largely on the effectiveness of various antifungal substances present in the host cuticle. The authors claim that differential susceptibility of different stages and sexes of mites can be attributed partially to the presence or absence of antifungal substances. This finding is in contrast with observations by Elliot (1998) on an epizootic of Neozygites tanajoae in the cassava green mite M. tanajoa in Brazil. Far fewer capilliconidia of the fungus were found on field-collected juveniles than on adult females, while the vast majority of killed mycosed mites were adult females. Elliot (1998) assumed that the limited movement of immature stages makes them less likely to pick up capilliconidia from the leaf surface. For additional information on the role of $N$. floridana in natural populations of spider mites is referred to Van der Geest et al. (2000).

\subsubsection{The Cassava Green Mite and Neozygites tanajoae}

The unfortunate introduction of the cassava green mite (GCM), M. tanajoa, from Latin America into East Africa during the 1970s led to a comprehensive search for natural enemies of this pest. The mite dispersed within 10 years across the cassava belt in Africa, threatening cassava production in vast areas of the continent (Yaninek, 1988). It was already clear from the beginning that chemical control of the CGM would be no option. Cassava is a marginal crop in Africa and the farmers would not be able to afford the cost of chemical control. Moreover, chemical control would result in an unacceptable environmental pollution in large parts of the continent. It was clearly understood that classical biological control would be the most desirable solution for the problem. Several predatory mites of the family Phytoseiidae were collected in various locations in Latin America and introduced into Africa.

During the search for natural enemies, also a species of Neozygites was found, first in Venezuela (Agudela-Silva, 1986), later also in Brazil by Delalibera et al. (1992). The fungus has a very narrow host spectrum and does not infect other spider mites or predatory mites. The fungus, initially considered to be $N$. floridana, but later described by Delalibera et al., (2004) as Neozygites tanajoae, is considered a good candidate as biological control agent for the CGM in Africa, because of its high specificity (De Moraes \& Delalibera, 1992). A drawback, however, is the fact 
that the fungus cannot successfully be grown on artificial media (Leite, Smith, De Moraes, \& Roberts, 2000), which means that it should be released in the field in the form of fungus infected dead mites. A detailed study was therefore performed in order to gain information on the suitability of the fungus as biocontrol agent. In a series of experiments, Oduor, De Moraes, Yaninek, and Van der Geest (1995a), Oduor, Yaninek, Van der Geest, and De Moraes (1995b), Oduor (1995c), Oduor, De Moraes, Van der Geest, and Yaninek (1996a), Oduor, Yaninek, Van der Geest, and De Moraes (1996b), Oduor, De Moraes, Van der Geest, and Yaninek (1997a) and Oduor, Sabelis, Lingeman, De Moraes, and Yaninek (1997b) studied the biology of $N$. tanajoae and its effect on the CGM. They demonstrated that the production of primary conidia is affected by ambient humidity, temperature and photoperiod: production of conidia increased with higher temperatures between $13^{\circ} \mathrm{C}$ and $23^{\circ} \mathrm{C}$, but no conidia production was obtained above $28^{\circ} \mathrm{C}$. Also, germination of capilliconidia on cassava green mites is affected by exposure time, temperatures, ambient humidity and photoperiod.

Infectivity of capilliconidia is lost after several days: only $3.5 \%$ of the spores germinate after a storage period of 10 days. It was also found that germination occurred at all temperatures studied $\left(13-33^{\circ} \mathrm{C}\right)$, even at $13{ }^{\circ} \mathrm{C}$, more than $15 \%$ of the capilliconidia germinated. This is an indication that the minimum temperature for germination may still be lower. An interesting observation is also that more capilliconidia germinate at $18^{\circ} \mathrm{C}$ than at higher temperatures. Germination in the dark is considerably higher than in light, while this process is also greatly affected by ambient humidity. The fungus apparently sporulates under natural conditions early in the morning before sunrise when the temperature is still low and the relative humidity high. Primary conidia can then disperse and produce capilliconidia that wait on the leaf surface to be picked up by a suitable host.

$N$. tanajoae cannot be mass produced in artificial culture media. Propagation needs to be performed in live mites, which is a laborious, and also expensive process. Storage of dead, non-sporulating infected mites (also called mummies) appears to be possible over prolonged periods of time in well-sealed plastic containers with cotton wool partially soaked in glycerol to establish a low humidity. In this manner, the fungus remains viable for periods of 6-7 months.

The fungus causes significant reductions in cassava green mite populations in cassava fields in the State of Bahia, Brazil (Delalibera, De Moraes, \& Sosa Gomez, 1999), reaching infection levels up to $75 \%$ during the wet season. Elliot et al. (2000) conducted a 4-year study in cassava fields in a semi-arid region in northeastern Brazil. The authors found that the fungus had a significant effect on CGM populations, but results were not very consistent for the different years. The fungus was not found in live mites during dry periods and for that reason it was assumed that resting spores were the most feasible mechanism to survive these periods of drought. Resting spores were found in great numbers during an epizootic in 1995, but they were not found in epizootics in early and mid 1998. Elliot (1998) considered perennial survival in the field of the fungus in mummies highly improbable as experiments had demonstrated that no viable fungus could be detected in dead mites after 2 month of hot and dry storage, both in the field and in the laboratory. In a later report, Elliot, De Moraes and Mumford (2008) discussed results of an experiment in 
which they monitored a population of the CGM and its natural enemies in central Bahia. Despite the presence of very high levels of the predatory mite Neoseiulus idaeus, there was an overexploitation of the cassava plants by the cassava green mite, which led to a total leaf loss. A simple regression model predicted a potential epizootic by $N$. tanajoae, but at that time, no inoculum of the fungus was present. There could have been an epizootic after the CGM population crashed, but then there were no hosts present to infect. The study showed the ineffectiveness of the predator and the importance of a correct timing of the pathogen. The authors concluded that the fungus may be a useful addition to biological control in this system with another predator than $N$. idaeus.

Yaninek et al. (1996) carried out a survey of fungi occurring in mites in the Republic of Benin, West Africa and found $N$. tanajoae in CGM and in Oligonychus gossypii. The fungus was present during the entire year, although the incidence of the disease was considerably greater in the wet season. Infection levels reached by the Benin strain were never as high as those of the Brazilian isolates where infection levels close to $100 \%$ may sometimes be reached. However, disease incidences in $O$. gossypii were about twice as high as in CGM. This species of mite is indigenous to Africa, in contrast to the cassava green mite. The $N$. tanajoae strains native to Africa are thought to be weakly pathogenic towards the CGM as they cause only low levels of mortality in CGM populations.

Based on these studies, N. tanajoae pathotypes from Latin America were being considered as a biological control agent of the CGM in Africa. An international collaboration between the International Institute for Tropical Agriculture (IITA, Cotonou, Benin), Empresa Brasileira de Pesquisa Agropecuária (EMBRAPA, Brazil) and the University of Amsterdam (The Netherlands) was set up in order to guide the introduction and release of the fungus into Africa. An in vivo release procedure has been developed at the (IITA) as it is not yet possible to culture the fungus in artificial culture media. Field experimental releases were performed in order to test the possibility to induce the development of epizootics in the field (Hountondji, 2005). The in vivo release method consisted of the release of 1-day old infected mites on young leaves of with CGM infested cassava fields Two different Brazilian strains were released in Southeastern Benin, resulting in disease incidence levels of 34 and $26.5 \%$ respectively, while the maximum prevalence for a Beninese isolate was only $4.5 \%$. The fungus is in the first site endemically present, but had never been found in northeastern Benin. Post-release monitoring in Southeastern Benin showed after 10 months the presence of the fungus in 3 out of 20 cassava field where the fungus had been released. In Northeastern Benin, epizootics were also observed with infection levels between 15 and $70 \%$. An interesting observation is that infection levels were consistently higher in fields inoculated with Brazilian isolates compared to those inoculated with the Beninese isolates.

The epizootics were especially observed during periods of hot days and cool nights with high relative humidity. The establishment of the Brazilian isolates at the release site could be confirmed. However, resting spores, believed to be essential for 
the survival of the fungus during dry periods were hardly found. Further studies will be needed to determine the suitability of the fungus as biocontrol agent of the CGM in Africa.

Hountondji (2008) discussed the interactions within the cassava green miteNeozygites tanajoae system. He states that most fungal pathogens lack the capacity to search for their hosts but that they have rather developed a sit-and-wait strategy. Field applications of $N$. tanajoae against the CRM has resulted in only limited success and for that reason, studies were conducted on the tritrophic interactions in the system. An interesting finding is that herbivores trigger the release of volatile chemicals (HIPV) that promotes sporulation of the fungal pathogen, whereas the host mites avoid the haloes of conidia. However, the mite does not avoid the pathogen when the fungus is inside the mummified cadaver. Mechanically damaged leaves produce also volatile, but these "green leaf volatiles" seem to delay sporulation. Hountondji (2005) speculates that a delay in the formation of conidia until the HIPV's are produced is to the advantage of the fungus. The production of HIPV's is a signal for the fungus that herbivores (hosts for the fungus) are present.

\subsection{Deuteromycetes}

The Deuteromycetes, also mitosporic or anamorphic fungi, and formerly called the Fungi Imperfecti, is a group of fungi of which no sexual stage is known. It is difficult to place these fungi in the fungus classification system, since this classification is mainly based on the mode of sexual reproduction. The majority of Deuteromycetes are probably the asexual stages of Ascomycota and Basidiomycota, with the largest number belonging to the Ascomycota. The approximately 20,000 species (2,600 genera) of Deuteromycetes (or Deuteromycota) lack any common phylogenetic origin or relationship and have only been grouped together for the sake of convenience. Classification of Deuteromycetes is mainly based on morphological similarities. The criteria typically used are color, shape, size and septation of the conidia (whether the spores are unicellular, or made up of multiple cells). The effect of this classification is that unrelated fungi have been "lumped" together while possibly related fungi have been classified into different form-classes because of differences in the visual appearance of the spores. When the sexual stage (teleomorph) is discovered, the correct name of the fungus will be that of the teleomorph.

A group in the Deuteromycetes is the form-class Hyphomycetes. These fungi have a mycelium but lack a sporocarp (structure in which spores are formed). The spores are borne on separate or aggregated conidiophores (stroma). We speak of a synnema when the conidiophores are united at the base and of a sporodochium when the hyphae are aggregated to a cushion-line structure on which the conidiophores are formed. Many of the spores of the Deuteromycetes have morphologically distinct features so that the spores of this group are some of the most easily identified. These fungi are also easily cultured so that more research has been conducted on this group of fungi than on many others. 


\subsubsection{Hirsutella Infections in Mites}

A well-known genus in the Hyphomycetes is Hirsutella. Approximately 80 species have been described in this genus; most species are pathogenic to tropical invertebrates, some are pathogens of Acari, in particular of eriophyids. Teleomorphs of Hirsutella have been reported as Cordyceps and Torrubiella spp. (cf. Chandler et al., 2000). Hirsutella species observed in mites are given in Table 3.

The first published report of a Hirsutella infection in an eriophyid goes back to 1924: Speare and Yothers (1924) observed a sudden decimation of a large population of the citrus red mite (CRM) (Phyllocoptruta oleivora) on grapefruit in Florida. The population density of CRM was in June sometimes extremely high with 5,000 mites on a single grapefruit, but soon after the maximum density had been reached, populations went down to almost zero. The authors were able to discern fungal hyphae in mite cadavers and also noted that disease incidence was much lower after application of a fungicidal copper spray. Fisher (1950) described this fungus later as Hirsutella thompsonii (Fig. 3).

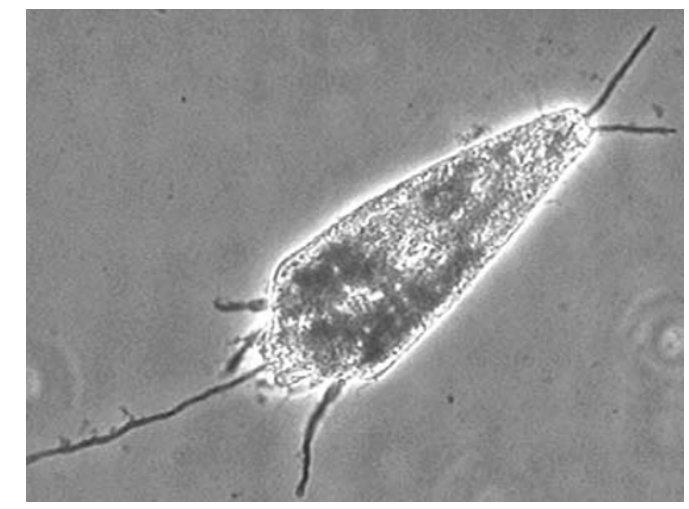

Figure 3. Epitremerus goniathrix (Eriophyidae), infected by Hirsutella sp. Photograph: Leo P.S. van der Geest.

The conidia are the infective propagules of the fungus. They are formed on phialides (flask-like conidiophores) that taper into a long narrow neck, and produce usually only 1-3 conidia in a dense terminal sphere of slime. This gives the impression that only one spore on each phialide is produced (Fig. 4). The mucous coat facilitates adhesion of the spores to the host cuticle. Penetration of the fungus is usually through all parts of the host's body, but in case of spider mites, it is usually through the legs. The fungi enter the host through the cuticle which is composed of about $30 \%$ chitin embedded in a protein matrix. Entomogenous fungi often produce proteases that may play a role in the early stages of penetration by exposing the chitin fibrils. Subsequently, chitinolytic enzymes are excreted that causes degradation of the fibrils into chains of glucose-N-acetyl of variable length. 
Table 3. Hirsutella species infecting mites and their hosts.

\begin{tabular}{|c|c|c|c|}
\hline Fungus species & Mite species & Mite family & Reference \\
\hline \multirow[t]{8}{*}{ Hirsutella sp. } & Amrineus cocofolius & Eriophyoidea & Van der Geest et al. (2002) \\
\hline & Epitremerus goniathrix & & \\
\hline & Mononychellus sp. & Tetranychidae & Bartkowski et al. (1988) \\
\hline & Notostrix attenuata & Eriophyoidea & Van der Geest et al. (2002) \\
\hline & Pronematus sp. & Tydeidae & Cabrera and McCoy (1984) \\
\hline & Propilus syagris & Eriophyoidea & Van der Geest et al. (2002) \\
\hline & Retracus jonhstoni & & \\
\hline & Tarsonemus sp. & Tarsonemidae & Van der Geest et al. (2002) \\
\hline H. brownorum & Mites in soil & & Humber (1992) \\
\hline \multirow[t]{2}{*}{ H. gregis } & Abacarus hystrix & Eriophyoidea & $\begin{array}{l}\text { Minter, Brady, and Hall } \\
\text { (1983) }\end{array}$ \\
\hline & Unidentified sp. & Acaridae & $\begin{array}{l}\text { Miętkiewski, Bałazy, and } \\
\text { Tkaczuk (2000) }\end{array}$ \\
\hline H. danubiensis & Tetranychus urticae & Tetranychidae & Bałazy et al. (2008) \\
\hline \multirow[t]{3}{*}{ H. haptospora } & Uropodina sp. & Uropodoidea & Humber (1992) \\
\hline & Urobovella sp. & Uropodoidea & Miętkiewski et al. (2000) \\
\hline & Unidentified species & Parasitiformes & Miętkiewski et al. (2000) \\
\hline \multirow[t]{5}{*}{ H. kirchneri } & Abacarus hystrix & Eriophyoidea & Minter et al. (1983) \\
\hline & $\begin{array}{l}\text { Eutetranychus } \\
\text { orientalis }\end{array}$ & Tetranychidae & $\begin{array}{l}\text { Sztejnberg, Doron-Shloush, } \\
\text { and Gerson (1997) }\end{array}$ \\
\hline & $\begin{array}{l}\text { Hemisarcoptes } \\
\text { coccophagus }\end{array}$ & Hemisarcoptidae & Sztejnberg et al. (1997) \\
\hline & Panonychus citri & Tetranychidae & Sztejnberg et al. (1997) \\
\hline & Phyllocoptruta oleivora & Eriophyoidea & $\begin{array}{l}\text { Cabrera and Dominguez } \\
\text { (1987a) and Sztejnberg } \\
\text { et al. (1997) }\end{array}$ \\
\hline \multirow[t]{2}{*}{ H. necatrix } & Abacarus hystrix & Eriophyoidea & Minter et al. (1983) \\
\hline & $\begin{array}{l}\text { Tetranychus } \\
\text { cinnabarinus }\end{array}$ & Tetranychidae & Sztejnberg et al. (1997) \\
\hline
\end{tabular}


Table 3 continued

\begin{tabular}{|c|c|c|c|}
\hline & Dendrolaelaps cornutus & Digamasellidae & Miętkiewski et al. (2000) \\
\hline \multirow[t]{4}{*}{ H. nodulosa } & Aceria guerreronis & Eriophyoidea & $\begin{array}{l}\text { Cabrera and Dominguez } \\
\text { (1987b) }\end{array}$ \\
\hline & Phyllocoptruta oleivora & Eriophyoidea & $\begin{array}{l}\text { Cabrera and Dominguez } \\
\text { (1987a) }\end{array}$ \\
\hline & $\begin{array}{l}\text { Polyphagotarsonemus } \\
\text { latus }\end{array}$ & Tarsonemidae & $\begin{array}{l}\text { Peña, Osborne, and Duncan } \\
\text { (1996) }\end{array}$ \\
\hline & $\begin{array}{l}\text { Steneotarsonemus } \\
\text { fragariae = } \\
\text { Phytonemus pallidus }\end{array}$ & Tarsonemidae & Miętkiewski et al. (2000) \\
\hline \multirow[t]{2}{*}{ H. rostrata } & $\begin{array}{l}\text { Dendrolaelaps } \\
\text { tetraspinosus }\end{array}$ & Digamasellidae & $\begin{array}{l}\text { Bałazy and Wiśniewski } \\
\text { (1989) }\end{array}$ \\
\hline & Proctolaelaps sp. & Ascidae & $\begin{array}{l}\text { Bałazy and Wiśniewski } \\
\text { (1989) }\end{array}$ \\
\hline \multirow[t]{15}{*}{ H. thompsonii } & Abacarus hystrix & Eriophyoidea & $\begin{array}{l}\text { Lewis, Heard, Brady, and } \\
\text { Minter (1981) }\end{array}$ \\
\hline & Acalitus vaccinii & Eriophyoidea & Baker and Neunzig (1968) \\
\hline & Aceria cynodoniensis & Eriophyoidea & McCoy (1996) \\
\hline & Aceria guerreronis & Eriophyoidea & Humber (1992) \\
\hline & Aceria sheldonii & Eriophyoidea & $\begin{array}{l}\text { McCoy (1996) and Sosa } \\
\text { Gomez and Moscardi (1991) }\end{array}$ \\
\hline & Aceria sp. & Eriophyoidea & McCoy and Selhime (1977) \\
\hline & Aculops lycopersici & Eriophyoidea & In: Chandler et al. (2000) \\
\hline & Calacarus heveae & Eriophyoidea & $\begin{array}{l}\text { Tanzini, Alves, Tamai, De } \\
\text { Moraes, and Ferla (2000) }\end{array}$ \\
\hline & $\begin{array}{l}\text { Colomerus } \\
\text { novahebridensis }\end{array}$ & Eriophyoidea & $\begin{array}{l}\text { Hall, Hussey, and Mariau } \\
\text { (1980) }\end{array}$ \\
\hline & Epitremerus goniathrix & Eriophyoidea & Van der Geest et al. (2002) \\
\hline & Notostrix formosae & Eriophyoidea & Van der Geest et al. (2002) \\
\hline & Phyllocoptruta oleivora & Eriophyoidea & Fisher (1950) \\
\hline & Retracus elaeis & Eriophyoidea & Urueta (1980) \\
\hline & Rhynacus sp. & Eriophyoidea & $\begin{array}{l}\text { Cabrera, Caceras, and } \\
\text { Dominguez (1987) }\end{array}$ \\
\hline & Vasates destructor & Eriophyoidea & McCoy (1996) \\
\hline
\end{tabular}




\begin{tabular}{|c|c|c|c|}
\hline & $\begin{array}{l}\text { Polyphagotarsonemus } \\
\text { latus }\end{array}$ & Tarsonemidae & Peña et al. (1996) \\
\hline & Vasates mckenzie & Tarsonemidae & Miętkiewski et al. (2000) \\
\hline & $\begin{array}{l}\text { Dolichotetranychus } \\
\text { floridanus }\end{array}$ & Tenuipalpidae & Humber (1992) \\
\hline & Eutetranychus banksi & Tetranychidae & McCoy and Selhime (1977) \\
\hline & $\begin{array}{l}\text { Eotetranychus } \\
\text { sexmaculatus }\end{array}$ & Tetranychidae & McCoy and Selhime (1977) \\
\hline & $\begin{array}{l}\text { Eutetranychus } \\
\text { orientalis }\end{array}$ & Tetranychidae & $\begin{array}{l}\text { Gerson, Kenneth, and } \\
\text { Muttath (1979) }\end{array}$ \\
\hline & Mononychellus tanajoa & Tetranychidae & Yaninek et al. (1996) \\
\hline & Panonychus citri & Tetranychidae & McCoy and Selhime (1977) \\
\hline & Oligonychus gossypii & Tetranychidae & Yaninek et al. (1996) \\
\hline & $\begin{array}{l}\text { Tetranychus } \\
\text { cinnabarinus }\end{array}$ & Tetranychidae & $\begin{array}{l}\text { Cehrnin, Gafni, Mozes- } \\
\text { Koch, Gerson, and } \\
\text { Sztejnberg (1997) }\end{array}$ \\
\hline & Oligonychus ilicis & Tetranychidae & $\begin{array}{l}\text { Gardner, Oetting, and } \\
\text { Storey (1982) }\end{array}$ \\
\hline & Tetranychus urticae & Tetranychidae & Gardner et al. (1982) \\
\hline & Tetranychus turkestani & Tetranychidae & In: Chandler et al. (2000) \\
\hline & $\begin{array}{l}\text { Trachyuropoda } \\
\text { coccinea }\end{array}$ & Trachyuropodidae & $\begin{array}{l}\text { Bałazy and Wiśniewski } \\
\text { (1982) }\end{array}$ \\
\hline H. tydeicola & Lorryia formosa & Tydeidae & $\begin{array}{l}\text { Cabrera, see: Samson and } \\
\text { McCoy (1982) }\end{array}$ \\
\hline & Tydeus californicus & Tydeidae & $\begin{array}{l}\text { Cabrera, see: Samson and } \\
\text { McCoy (1982) }\end{array}$ \\
\hline & Tydeus gloveri & Tydeidae & Samson and McCoy (1982) \\
\hline H. vandergeesti & Amblyseius sp. & Phytoseiidae & Bałazy et al. (2008) \\
\hline & Neoseiulus sp. & & \\
\hline & Seiulus sp. & & \\
\hline & Typhlodromus sp. & & \\
\hline & Tarsonemus lacustris & Tarsonemidae & \\
\hline
\end{tabular}


When grown in artificial cultures, a toxic protein is produced with a molecular weight of 15-16 kDa (Vey, Quiot, Mazet, \& McCoy, 1993). This protein, hirsutellin A (HtA) is a heat stable, non-glycosylated protein with properties similar to ribosome-inhibiting proteins. It is a single chain polypeptide that is composed of 130 amino acids (Herrero-Galán et al., 2008). HtA shows ribotoxin activity and interacts with phospholipid membranes. When administered orally or by injection, it causes strong cytotoxic effects against several insect species (pycnosis of the nucleus and lesions in the midgut, malpighian tubules, hypodermis, fatbody, hemocytes, muscles and silk glands of larvae). The toxin affects a wide range of arthropods, including mites. It was tested against the citrus rust mite Phyllocoptruta oleivora, the natural host of the fungus, where it caused considerable mortality among adult mites, while oviposition of females was lowered prior to their death (Omoto \& McCoy, 1998). Maimala, Tarter, Bouciar, and Chandrapatya (2002) studied 162 strains of $H$. thompsonii and found that more than half of these strains produced the toxin. They were able to characterize the gene encoding for the toxin, but the presence of the gene could not be associated with enhanced insecticidal properties of the fungus. Other toxins have also been reported to be produced by Hirsutella sp., such as hirsutellin B and phomalactone. It is not within the scope of this manuscript to discuss these products further.

$H$. thompsonii regularly causes epizootics in populations of $P$. oleivora under natural conditions in Florida and affects both nymph and adult stages. The asexual spores are produced outside the host body on the plant surface. Conidia germinate under favorable conditions (high relative humidity) and enter the body by means of a germ tube. After penetration, a ramifying growth of the fungus can be discerned. The fungus erupts after

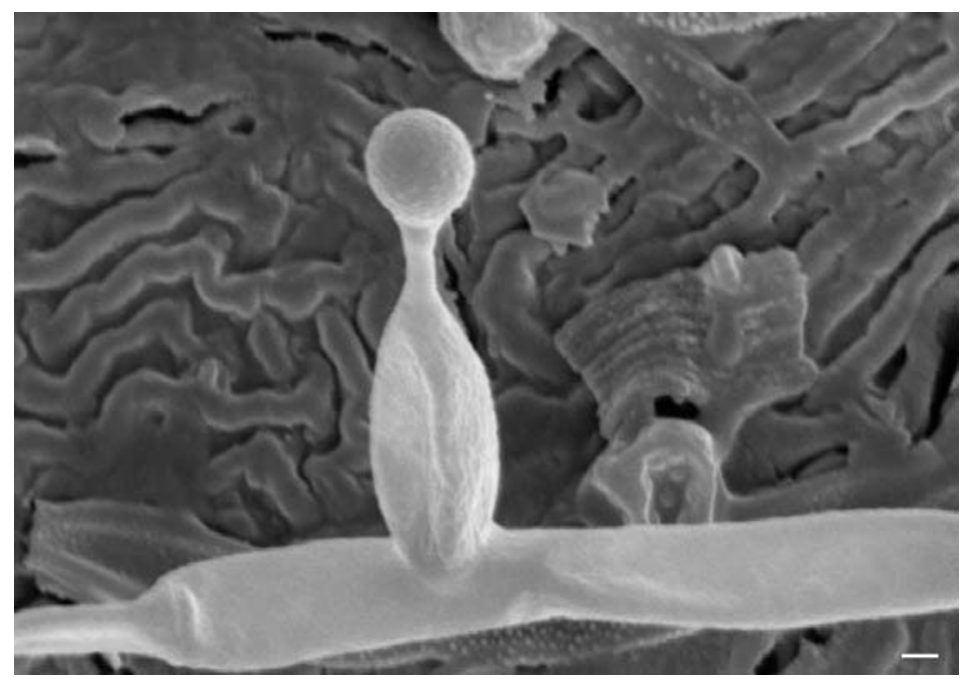

Figure 4. Phialid of Hirsutella thompsonii with conidia. The globular structure on top of the phialid may hold several conidia which are contained in a slimy sheath. Photograph courtesy of Dr. Marcel R. Tanzini. 
death of the mite through the cuticle and forms new spores. It takes about $4 \mathrm{~h}$ for a spore to penetrate the cuticle of the host, while time from infection to formation of new spores is around 4 days at $25-30^{\circ} \mathrm{C}$ (Fig. 4 ).

The fungus can easily be grown on artificial media and this property together with its high infective potential towards the citrus rust mite (CRM) has led to research aimed at the development of the fungus as biological control agent. Large-scale laboratory and industrial production methods have been developed for the production of mycelial and conidial preparations (McCoy, Hills, \& Kanavel, 1975; McCoy, 1981). It was planned to introduce the fungus early in the season as a prophylactic to reduce outbreaks of the CRM. Commercial production of conidial preparation in the USA was developed in 1975-1976 by Abbott Laboratories and full registration was received for a mycoacaricide for the control of eriophyids on citrus under the name Mycar ${ }^{\mathrm{TM}}$. Several hundreds of kilograms were sold of the product but commercial production was discontinued in 1985 as too many factors affected the stability and reliability of the acaricide.

Interest in the production of $H$. thompsonii based acaricides for use against eriophyids continued in other countries even after the production of Mycar $^{\mathrm{TM}}$ in the USA was discontinued. Experiments have been conducted in several countries, e.g. Brazil, Argentina, Mexico and Sri Lanka, but these studies have yet not led to a commercial biological control product. More successful were studies in India where the coconut mite, Aceria (Eriophyes) guerreronis, is a major constraint to coconut farming in India, the third largest producer of coconuts in the world. Biological control has been considered for a long time, despite the availability of other control methods, including chemical and botanical pesticides and nutrition-based cultural methods (Sreerama Kumar \& Singh, 2001; Sreerama Kumar, 2006). Research has resulted in the identification of the most infective mite pathogen, H. thompsonii, as important regulator of the coconut mite (Fig. 5). Further research had led to the production of a biological acaricide, Mycohit ${ }^{\mathrm{TM}}$, with a mixture of mycelium

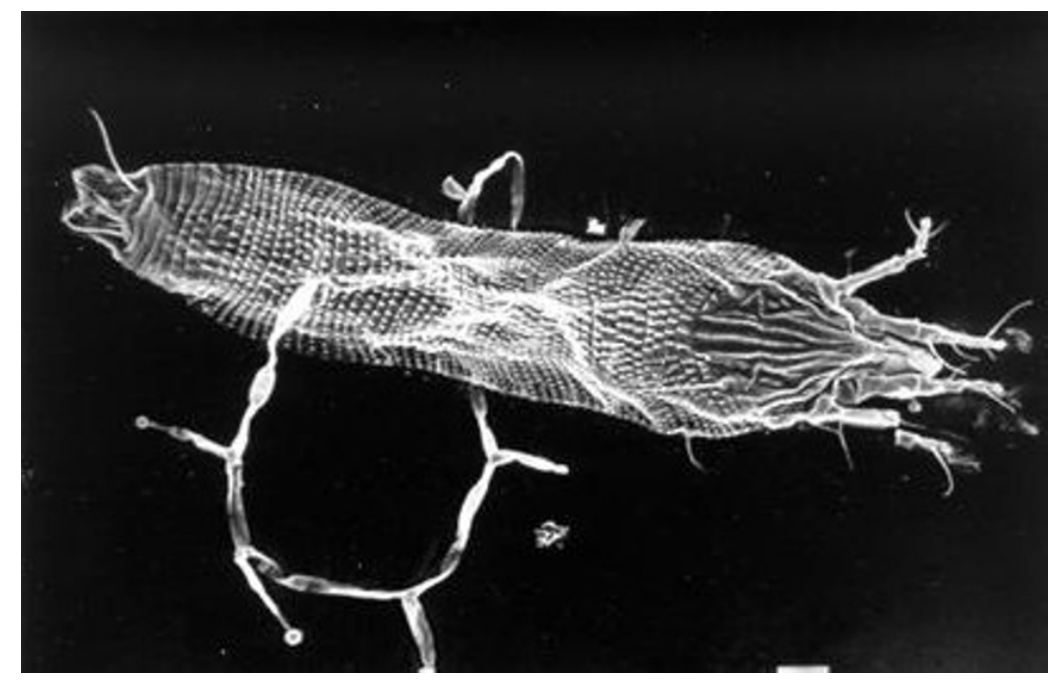

Figure 5. Aceria (Eriophyes) guerreronis infected by Hirsutella thompsonii. Photograph courtesy of Dr. P. Sreerama Kumar. 
and conidia as active ingredients. In a series of field experiments, it was shown that Mycohit $^{\mathrm{TM}}$ is a very effective acaricide that brings down the population to over $90 \%$. For the application of the product, youngsters are hired that climb into the trees in order to carry out the applications (Figs. 6 and 7).

Further research has led to the development of Mycohit- $\mathrm{M}^{\mathrm{TM}}$, a preparation that contains only mycelium (Sreerama Kumar \& Singh, 2008). The authors also studied the effect of several adjuvants (glycerol, yeast extract powder and dehydrated malt extract) on the growth and spore forming of the latter preparation. In the presence of these adjuvants $H$. thompsonii biomass produced under laboratory conditions more colonies and a higher number of conidia. These products also showed protection against sun irradiation under field conditions. Studies are presently also conducted in Brazil on the control of the coconut mite by use of $H$. thompsonii (cf. Van der Geest et. al., 2000). Various isolates of the fungus were introduced from Mexico into Brazil and were mass produced on rice and corn grids, but the mortality due to the fungus was too low (about 35\%). However, it was possible to increase the virulence of the fungus by passage through the host. The fungus has been established in the field, although damage due to A. guerreronis is still too high.

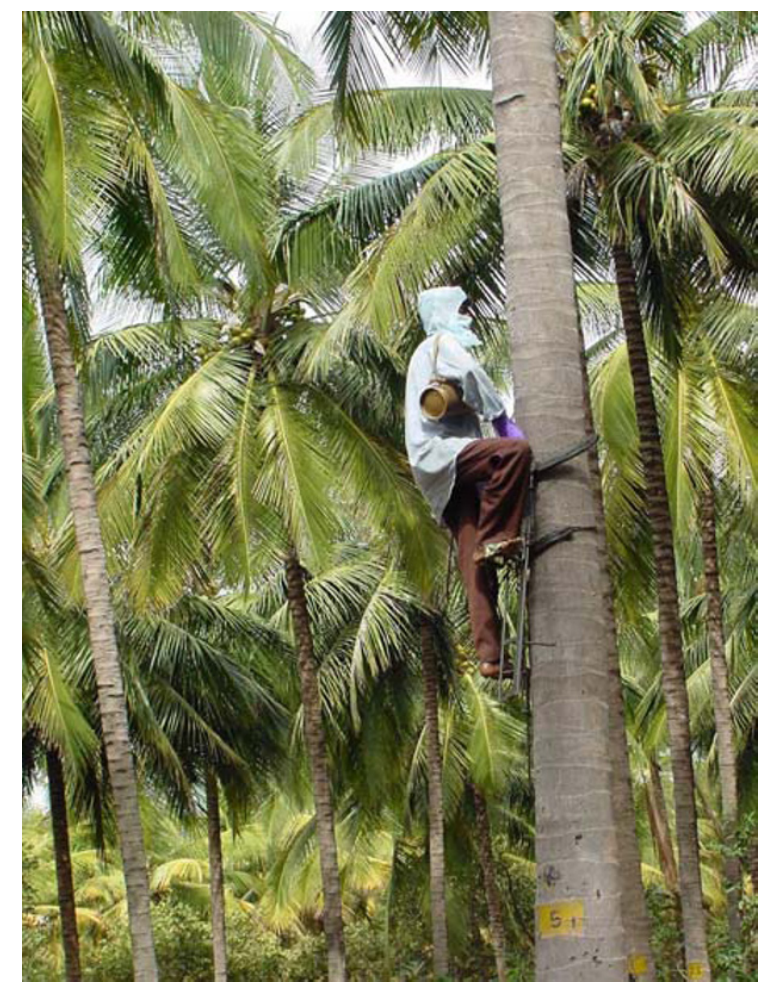

Figure 6. Spraying of coconut trees with Mycohit. Photograph courtesy of Dr. P. Sreerama Kumar. 
Several attempts have been made to use the fungus also for the control of other mite pests. However, most of these attempts were unsuccessful, as e.g. the control of spider mites ( $T$. cinnabarinus, Eotetranychus orientalis and $T$. urticae in greenhouses (Rombach \& Gillespie, 1988). Hirsutella kirchneri has also been considered a good candidate for the control of plant-inhabiting mites. Its pathogenicity was tested by Sztejnberg et al. (1997) against a number of different mites. It was shown to be effective against the eriophyid $P$. oleivora, and against the spider mites Eutetranychus orientalis, Panonychus citri, T. cinnabarinus and in some degree against Hemisarcoptes coccophagus (Hemisarcoptidae). However, no infectivity was found towards the broad mite Polyphagotarsonemus latus (Tarsonemidae), Rhizoglyphus robini, Tyrophagus putrescentiae (Acaridae) and Typhlodromus athiasae (Phytoseiidae). No infectivity was noted towards a number of beneficial arthropods.

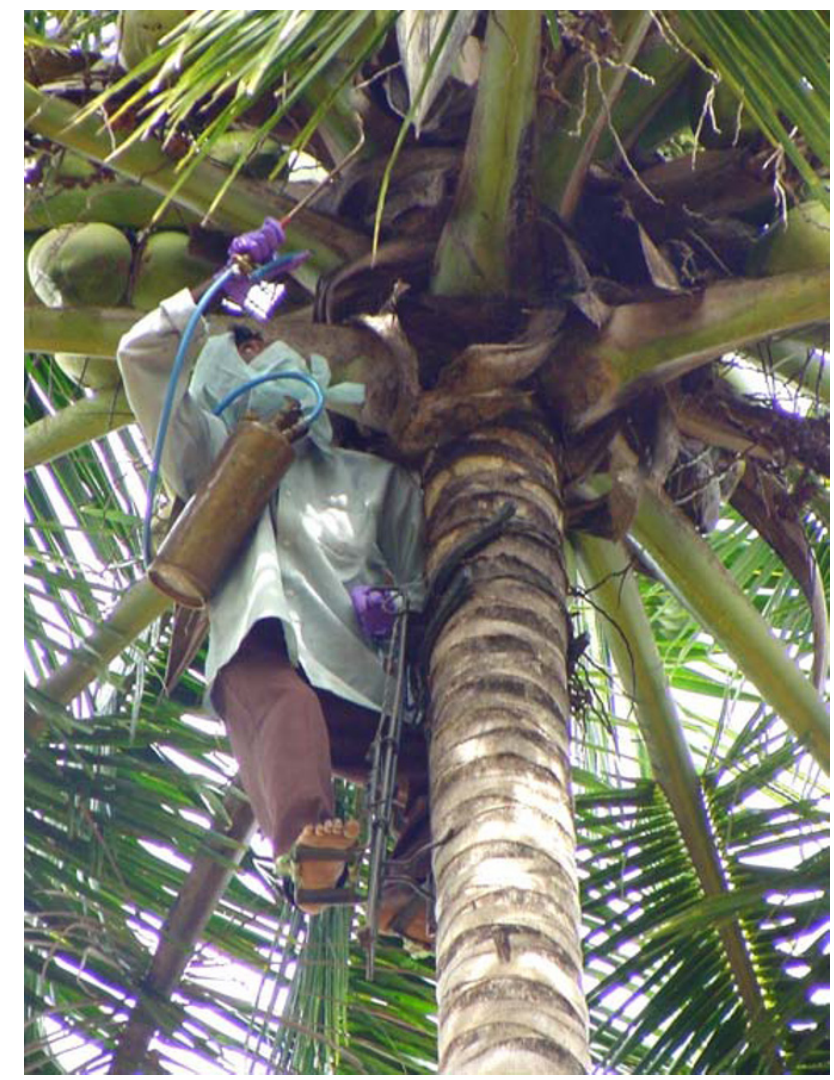

Figure 7. Spraying of coconut trees with Mycohit. Photograph courtesy of Dr. P. Sreerama Kumar.

A few reports deal with the occurrence of the $H$. thompsonii on the cassava green mite M. tanajoa in the cassava belt in Africa. Yaninek et al. (1996) observed 
the fungus on CGM and on Oligonychus gossypii during an inventory in Benin, and Odongo, Odindo, Brownbridge, and Kumar (1998) carried out experiments in which CGM infected plants were treated with suspensions of $H$. thompsonii. In the treated plots, $76.6 \%$ disease incidence was obtained, but rainfall caused a reduction in disease prevalence in the mites. The authors concluded that the application of the fungus has promise for controlling the CGM, but that the fungus should be applied in harmony with other natural mortality factors such as rainfall.

The fungus has also been recorded in Calacarus heveae (Eriophyidae) an important pest in rubber plantations in Brazil (Tanzini et al., 2000). This mite is a major pest in the Michelin rubber plantation in Itiquira, Mato Grosso, where it causes considerable economic damage. Calacarus heveae feeds on the upper side of the leaves, in contract to most other rust mites (Figs. 8 and 9). Populations of several hundreds of mites per rubber tree leave are no exception. However, the mite populations are usually decimated after a few weeks by the action of Hirsutella thompsonii (Figs. 9 and 10). These epidemics are usually too late to avoid damage to the plantation (defoliation of the trees).

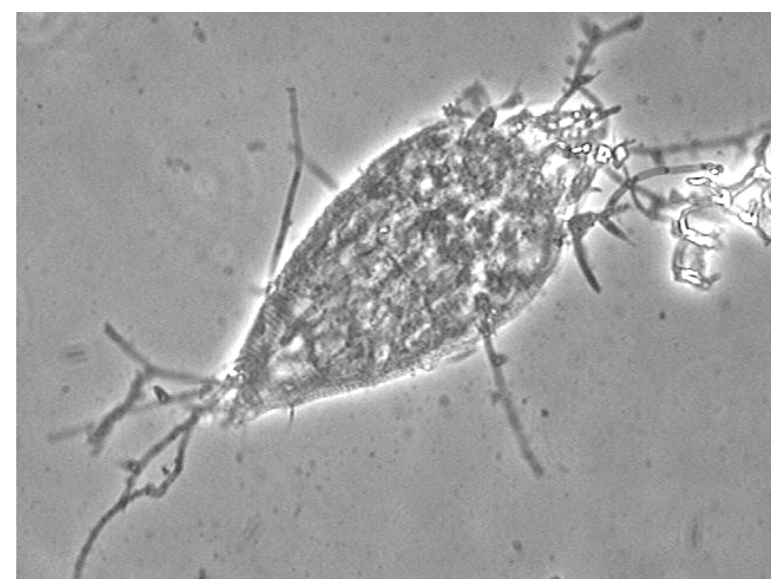

Figure 8. Calacarus heveae, killed by Hirsutella thompsonii. Photograph:

Leo P.S. van der Geest.

Hirsutella thompsonii is normally associated with prostigmatic mites (Eriophyidae and Tetranychidae), although it has also been observed to infect mesostigmatic mites (McCoy \& Selhime, 1977; Bałazy \& Wiśniewski, 1982).

Gerson, Gafni, Paz, and Sztejnberg (2008) tested Hirsutella thompsonii, $H$. kirchneri and $H$. necatrix with respect to their effect on several mite species: spider mites, rust mites, broad mites, but also scavengers and predatory mites were included in the study. The results of these experiments led to the conclusion that none of these fungus species gave satisfactory control of mite pests, neither in greenhouses, nor outdoors. 


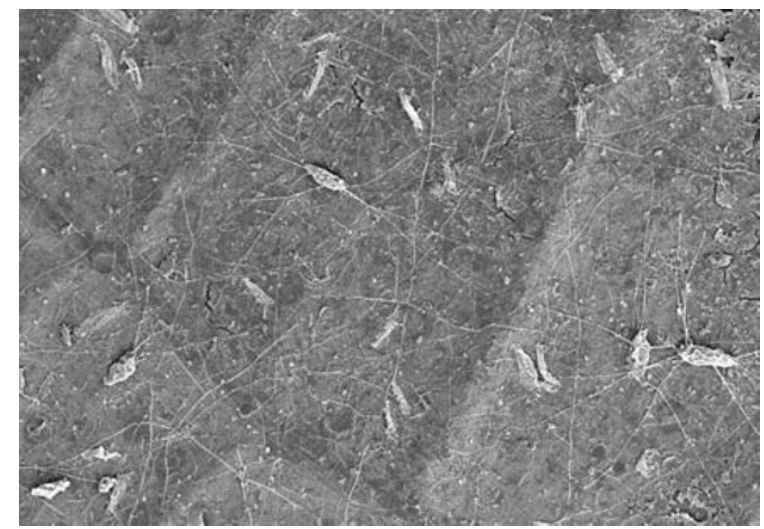

Figure 9. Rubber tree leaves with numerous cadavers of Calacarus heveae. The mites have been killed by the fungus Hirsutella thompsonii. However, the disease cannot prevent substantial economic damage to the rubber plantations in Itiquira, $M G$, Brazil, as the epidemics come too late in the season. Photograph courtesy of Dr. Marcel R. Tanzini.

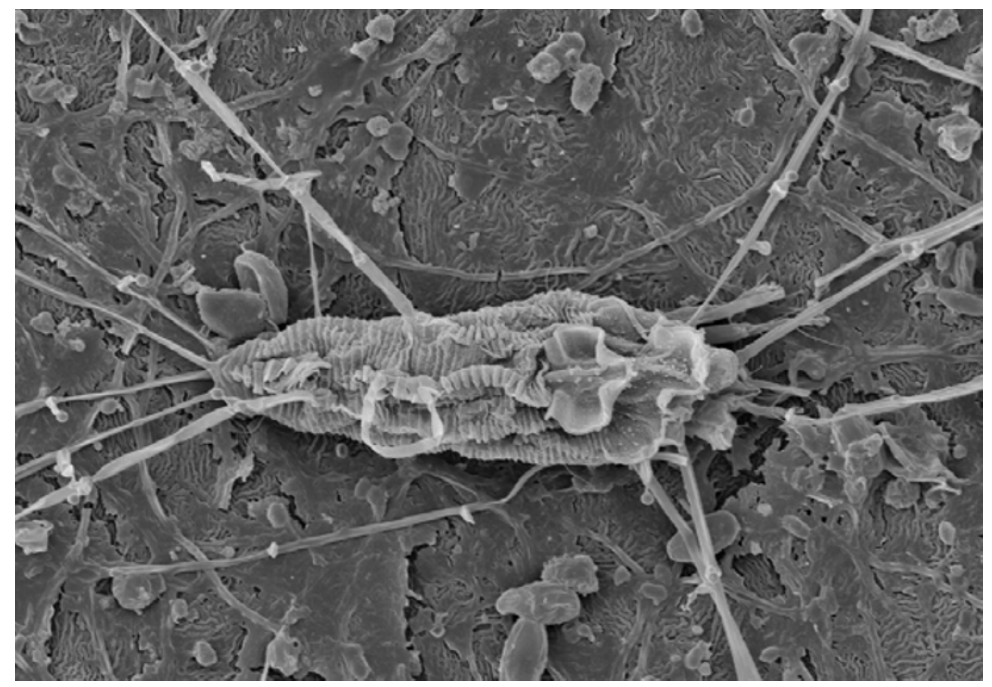

Figure 10. Calacarus heveae (Eriophyidae), killed by Hirsutella thompsonii. Photograph courtesy of Dr. Marcel R. Tanzini.

\subsubsection{Other Deuteromycetes Infecting Mites}

Some of the other Deuteromycetes are probably the most comprehensively studied entomopathogenic fungi. However, of these fungi, only few records have been made of natural infections in mites. Leatherdale (1965) observed a mycosis of the blackcurrant mite Cecidophyopsis ribis by Paecilomyces eriophytis, later also found 
in Italy on Phytoptus avellanae, a mite causing big bud disease in ornamental and fruiting hazel (Corylus avellana). Experiments were carried out with the fungus isolate from $C$. ribis to infect the European red mite Panonychus ulmi and the eriophyids Aceria hippocastani (from horse chestnut) and Cecidophyes galii (from goosegrass). The fungus proved to be pathogenic for the first two species, but no infection was obtained in $C$. galii. The fungus has also been reported by Baker and Neunzig (1968): high infection rates were noted in the blueberry bud mite Aceria vaccinii (Eriophyidae) in North Carolina, USA, when high temperatures coincided with heavy rainfall and high relative humidity. Disease incidence declined from August onwards, when conditions were less favorable for the fungus. The population density of the blueberry mites then increased.

One of the earliest experiments in which a fungus was tested against a phytophagous mite was a field application of B. bassiana spores for the control of the twospotted spider mite T. urticae (Dresner, 1949). Mites were treated with a dust containing $0.5 \%$ spores of the fungus, resulting in a mortality of $71 \%$. However, these experiments did not lead to the development of a microbial acaricide.

Deuteromycetes have widely been studied for the control of insect (and in a few instances mite) pests. A number of these fungi (e.g. Metarhizium, Beauveria) have a broad host spectrum and can easily be mass produced on relatively simple culture media. In Brazil, research is being conducted to evaluate several Deuteromycetes as possible control agent of the twospotted spider mite (Tamai, Alves, Lopes \& Neves 1998). They tested 152 different isolates for the fungi B. bassiana, B. brongniartii, Beauveria sp., Metarhizium sp., Paecilomyces lilacinus and P. farinosus. Only isolates of Beauveria spp. caused mortality between 35 and $95 \%$. The pathogenicity of some isolates was further tested: one isolate gave even better control than obtained with chemical pesticides. The fungus was also effective against other pests in chrysanthemum, such as thrips and aphids (Alves, Tamai, \& Lopes, 1998).

Three different fungus species were investigated by Peña et al. (1996) with respect to their potential as biological control agent of the broad mite Polyphagotarsonemus latus (Tarsonemidae). This very polyphagous pest species thrives under warm and humid conditions, and this seemed to be a good reason to study the feasibility of using fungi as control agents. Three fungi were tested: $B$. bassiana, $H$. thompsonii and Paecilomyces fumosoroseus under controlled temperature and humidity conditions in the laboratory and in the greenhouse. All fungi were capable to infect the mites: higher doses resulted in a faster death of the mites, while density of the mites also affected disease incidence. The authors concluded from their experiments that the fungus selected should cause epizootics within 2-3 days following application. Promising results for the control of the broad mite on mulberry have been obtained with M. anisopliae by Maketon, OroszCoghlan, and Sinprasert (2008). The fungus is effective against larvae and adults, but no ovicidal effect was noted. The broad mite has also been found in association with Hirsutella nodulosa (Peña et al., 1996). No other associations of this mite with fungi have been reported.

Shi, Feng, and Liu (2008) noted an ovicidal effect of sprays of an emulsifiable $B$. bassiana formulation against the twospotted spider mite $T$. urticae. The fungal isolate was obtained from mycosed aphids and has been formulated for the control 
of whiteflies in greenhouses. The dried conidial powder was suspended in a mixture of $95 \%$ industrial paraffin as oil carrier and 5\% fatty alcohol polyethylene glycol ether as emulsifier. The authors are of the opinion that the formulation has greatly enhanced egg mortality, also at lower relative humidities. Oily formulations may give a better attachment of the conidia to the target pest and a better protection of the conidia against desiccation. The formulation has also provided significant control of the citrus rust mite in orchards in East China and of T. truncates and T. turkestani in cotton in the Tarim Basin of northwest China.

Isolates of fungi may show large differences in virulence to their hosts. For example, Bugeme, Maniania, Knapp, and Boga (2008) studied 23 isolates of Metarhizium anisopliae and 3 isolates of $B$. bassiana with respect to their pathogenicity versus the spider mite $T$. evansi. Temperature greatly affected observed mortality of the spider mites, but also germination of the spores and growth were affected and varied with isolate.

The fungi $M$. anisopliae and $H$. thompsonii are being investigated as control agents of Varroa jacobsoni (Kanga, James, \& Boucias, 2002). They are pathogenic for the varroa mite and the conditions under which they can infect mites are similar to those found in bee colonies. Meikle, Mercadier, Holst, and Girod (2008) studied the impact of formulations of B. bassiana on varroa mites and on the honey bees. They formulated conidial preparations of two strains of the fungus with either carnauba or candelilla wax powder and studied the effect on colony health and mite fall (mortality). Bees were nof affected by the fungal preparations, but mite fall was consistently higher than the control. Results were encouraging, but more knowledge should be acquired on conidia dosage, number of applications and conditions within the bee hives.

Eken and Hayat (2008) conducted an inventory for natural enemies of the twospotted spider mite Tetranychus urticae in Turkey. They found several isolates of Cladosporium cladosporioides (Moniliaceae), that were subsequently tested in the laboratory with respect to their pathogenicity towards T. urticae. The fungus caused mortality levels of $51-75 \%$ when sprayed on leaflets infested with twospotted spider mites. These results are encouraging and additional experiments should be conducted. Cladosporium infections were also found by Van der Geest et al. (2002) in Retracus johnstoni, an eriophyid feeding on the palm tree Syagrus romanzoffiana in Brazil. The fungus has been isolated on potato-dextrose agar, but no further experiments have been carried out with this isolate.

Interesting experiments were performed by Sanassi and Amirthavalli (1970) with the velvet mite Trombidium gigas (Trombidiidae). Mite were infected with spores of the fungus Aspergillus flavus, a fungus also capable of infecting humans and problematic in foods as it produces the very toxic aflatoxin. Three different methods were applied: injection of spore suspensions into the body cavity, spraying of spore's suspensions on the integument of the mite and dusting of spores on the integument. In all cases infection of the mites was obtained. Changes in the structure of the integument were noted (Sanassi \& Oliver, 1971). The first sign of the disease is the loss of the scarlet-red plumose cuticular setae of the mites. Each seta consists of a main central stem from where minor secondary branches arise. The base of the 
central stem is normally slightly enlarged and is buried in sockets present in the epiand procuticle.

The fungus apparently digests the lipoproteinaceous epicuticular layer that attaches the base to the cuticular sockets. Subsequently, the process is followed by additional chemical changes in the composition of the cuticle. Epidermal cells display interesting pathological symptoms. In uninfected mites, epidermal cells form a syncytium, but after infection a remarkable reaction occur in these cells. The cells line up in almost a single row just below the outer limiting border of the epidermis. Vacuoles appear in the cytoplasm of the epidermal cells, while organelles such as mitochondria and Golgi apparatus are not anymore discernable.

In a search for control agents of the citrus red mites (CRM) in Israel, field collected mite cadavers were examined for the presence of pathogens. This has resulted in the finding of three species of fungi that were found to be associated with mites. The fungi were described by Boekhout et al. (2003) as novel species belonging to the Ustilagomycetes, a class that is also called the smut fungi. It is a large taxon with over 1,400 species in 70 genera that are almost exclusively plant pathogens. The three fungi are anamorphic (they have no sexual state) and belong therefore to the Deuterymycetes. However, morphologically they are similar to yeast-like fungi which have been classified in the Ustilaginales. Based on molecular properties, they should be considered to belong to two different lineages within the Exobasidiomycetidae of the Ustilaginomycetes (Basidiomycota). These fungi, described as Meira geulakonigii, M. argovae and Acaromyces ingoldii, are hard to isolate from field-collected material: they are slow-growing fungi and for their identification physiological and molecular methods are needed. This probably explains the fact that they have only recently been discovered.

The three fungi were further studied with respect to their potential as biological control agents of phytophagous mites. Laboratory investigations showed that all three fungi affected mites, although $M$. argovae showed no effect towards $T$. urticae. (Gerson et al., 2008). Meira geulakonigii caused considerable mortality of spider mites and citrus red mite. An interesting observation was that none of the fungi invaded the mites, although the fungi did grow on the mite's cadavers. It is assumed that mortality among the mites was caused by the action of fungal toxins.

Further tests showed that the fungus was endophytically present within the sealed grapefruit flowers and in the flavedo (the tough outer skin) of grapefruit. There was no evidence that the fungus caused any damage to the plants, which led the authors to the assumption that $M$. geulakonigii serves as a "body guard" of grapefruits. Also, M. geulakonigii had only minimal fungicidal effect on some predatory mites. This property, together with its tolerance to many insecticides and acaricides, suggests that this fungus has possibilities for integrated control programs.

\subsection{Ascomycota}

The Ascomycota is a large taxon of fungi with approximately 2,000 genera and over 30,000 species. Members of the Ascomycota bear the sexual spores within an ascus, originally a cell that at first contains a diploid nucleus resulting from karyogamy (the 
fusion of nuclei or nuclear material that occurs during sexual reproduction). The nucleus undergoes subsequently meiosis, resulting in the formation of haploid ascospores inside the asci. These asci are often borne in or on top of a sporocarp. Very few Ascomycota have been isolated from mites. These isolations concern mainly Laboulbeniales infections in a number of mite species. Laboulbeniales is an order of fungi with more than 2,000 species. They are small, often minute fungi that have an obligate association with arthropods, mainly insects, and they lack mycelium. On their host, they appear as scattered or densely crowded bristles or bushy hairs which may form furry or velvety patches on certain part of the host' integument. These plume-like structures and triggers help in ascospore release when the arthropod comes into contact with a mature thallus.

The site of attachment is usually limited to definite regions on the integument of each host. The entire thallus (body) is derived from enlargement and subsequent cell division of the two-celled ascospore. Below the surface of the arthropod cuticle absorption through a peg- or root-like haustorium provides a nutrition source for the fungus; however, the fungal parasites of this group do not appear to cause much damage to the host. A few species have been found on mites, including a Rickia sp. and an unknown species on Hirstionyssus (Demanyssidae) (Steinhaus \& Marsh, 1962).

\section{DISEASES CAUSED BY EUKARYOTIC MICROPARASITES}

Traditionally, the animal kingdom has been divided into two subkingdoms: the Protozoa (unicellular eukaryotes) and the Metazoa (multicellular animals). In modern taxonomy, a kingdom Protista is considered of which the members are either unicellular, colonial or multicellualar. All these organisms are eukaryotes,

The Protista are divided into three major groups: the Protozoa, the Algae and the Fungus-like protists. Protozoa are defined as single-celled eukaryotic organisms, that feed heterotrophically (feeding both on both organic and inorganic raw materials) and exhibit diverse motility mechanisms. Traditionally, four divisions are discerned, based on their mode of mobility:

- Flagellata (Mastigophora) are protozoa that move by means of flagellar action. Some flagellates have their flagella attached in a structure called an undulating membrane. They often have symbiotic relationships with multicellular organisms.

- $\quad$ Rhizopoda (Amoebozoa) Rhizopoda are protozoa that move by employing pseudopodia, which are covered by membranes. These pseudopodia are cytoplasmic extensions that are not only used for locomotion but also to engulf food. Amoebae live in moist terrestrial and aquatic environment.

- Apicomplexa (or Sporozoa). The Sporozoa are parasitic spore formers that do not move by their own power. Plasmodium vivax, the cause of malaria, is a sporozoan.

- Ciliata (Ciliophora) Ciliata are protozoa that move by means of cilia action. Cilia are small and numerous; flagella are large and few. Because of the tremendous variety in ciliary arrangements and functions, ciliates are among the most diverse cells in the biological world. 
Table 4. Protozoan infections in mites.

\begin{tabular}{|c|c|c|c|}
\hline Species & Mite host & Mite family & References \\
\hline \multicolumn{4}{|l|}{ Apicomplexa } \\
\hline $\begin{array}{l}\text { Acarogregarina } \\
\text { corolla }\end{array}$ & Scutovertex minutus & Scutoverticidae & Erhardová (1955) \\
\hline $\begin{array}{l}\text { Asterophora } \\
\text { caloglyphi }\end{array}$ & Caloglyphus moniezi & Acaridae & Geus (1969) \\
\hline \multirow[t]{3}{*}{$\begin{array}{c}\text { Erhardovina } \\
\text { bisphaera }\end{array}$} & Damaeus clavipes & Damaeidae & $\begin{array}{l}\text { Purrini and Ormieres } \\
\text { (1981) }\end{array}$ \\
\hline & Damaeus onustus & Damaeidae & $\begin{array}{l}\text { Purrini and Ormieres } \\
\text { (1981) }\end{array}$ \\
\hline & Eupelops hirtus & Eupelopidae & $\begin{array}{l}\text { Purrini and Ormieres } \\
\text { (1981) }\end{array}$ \\
\hline E. carabodesi & Carabodes coriaceus & Carabodidae & $\begin{array}{l}\text { Purrini and Ormieres } \\
\text { (1981) }\end{array}$ \\
\hline E. euzeti & Euzetes seminulum & Euzetidae & Lipa (1982) \\
\hline E. fuscozetesi & Fuscozetes setosus & Ceratozetidae & $\begin{array}{l}\text { Purrini, Bukva, and } \\
\text { Bäumler (1979) }\end{array}$ \\
\hline E. fuscozetesi & Euzetes globulus & Euzetidae & $\begin{array}{l}\text { Purrini and Ormieres } \\
\text { (1981) }\end{array}$ \\
\hline E. oribatarum & Mite & & see Lipa (1971) \\
\hline \multirow[t]{2}{*}{ E. phtiracari } & Phthiracarus globosus & Phthiracaroidea & $\begin{array}{l}\text { Purrini and Ormieres } \\
\text { (1981) }\end{array}$ \\
\hline & Phthiracarus piger & Phthiracaroidea & $\begin{array}{l}\text { Purrini and Ormieres } \\
\text { (1981) }\end{array}$ \\
\hline E. platynothri & Platynothrus peltifer & Nothroidea & $\begin{array}{l}\text { Purrini and Ormieres } \\
\text { (1981) }\end{array}$ \\
\hline E. postneri & Hermannia gibba & Hermannioidea & Purrini et al. (1979) \\
\hline E. scutovertexi & Scutovertex minutus & Scutoverticidae & Erhardová (1955) \\
\hline Erhardovina sp. & Limnochares aquatica & Hydrachnellae & Issi and Lipa (1968) \\
\hline \multirow[t]{3}{*}{ Gregarina sp. } & Eupelops subuliger & Eupelopidae & Purrini et al. (1979) \\
\hline & Eupelops torulosus & Eupelopidae & Purrini et al. (1979) \\
\hline & Rhysotritia ardua & Phthiracaroidea & Purrini et al. (1979) \\
\hline Erhardovina sp. & Damaeus geniculatus & Damaeidae & see Lipa (1971) \\
\hline
\end{tabular}


Table 4 Continued

\begin{tabular}{|c|c|c|c|}
\hline Erhardovina sp. & Damaeus oblongus & Damaeidae & see Lipa (1971) \\
\hline Gurleya sokolovii & Limnochares aquatica & Hydrachnellae & Issi and Lipa (1968) \\
\hline $\begin{array}{l}\text { Unidentified } \\
\text { gregarine }\end{array}$ & $\begin{array}{l}\text { Tyrophagus } \\
\text { putrescentiae }\end{array}$ & Acaridae & Steiner (1993) \\
\hline Adelina acarinae & Nothrus silvestris & Nothroidea & Purrini (1984) \\
\hline \multicolumn{4}{|l|}{ Microspora } \\
\hline Intexta acarivora & $\begin{array}{l}\text { Tyrophagus } \\
\text { putrescentiae }\end{array}$ & Tyroglyphidae & $\begin{array}{l}\text { Larsson, Steiner, and } \\
\text { Bjørnson, (1997) }\end{array}$ \\
\hline $\begin{array}{l}\text { Microsporidium } \\
\text { phytoseiuli }\end{array}$ & Phytoseiulus persimilis & Phytoseiidae & $\begin{array}{l}\text { Bjørnson, Steiner, } \\
\text { and Keddie (1996) }\end{array}$ \\
\hline Microsporidium sp. & Amblyseius barkeri & Phytoseiidae & $\begin{array}{l}\text { Beerling and Van der } \\
\text { Geest (1991a, 1991b) }\end{array}$ \\
\hline $\begin{array}{l}\text { Neoseiulus } \\
\text { cucumeris }\end{array}$ & & Phytoseiidae & $\begin{array}{l}\text { Beerling and Van der } \\
\text { Geest (1991a; 1991b) }\end{array}$ \\
\hline $\begin{array}{l}\text { Napamichum } \\
\text { aequifolium }\end{array}$ & Limnochares aquatica & Hydrachnellae & Larsson (1990) \\
\hline \multirow[t]{2}{*}{ Nosema acari } & Damaeus onustus & Damaeidae & $\begin{array}{l}\text { Purrini and Weiser } \\
\text { (1981) }\end{array}$ \\
\hline & Damaeus clavipes & Damaeidae & $\begin{array}{l}\text { Purrini and Weiser } \\
\text { (1981) }\end{array}$ \\
\hline N. euzeti & Euzetes seminulum & Euzetidae & Lipa (1982) \\
\hline N. führeri & Phthiracarus globosus & Phthiracaroidea & $\begin{array}{l}\text { Purrini \& Weiser } \\
\text { (1981) }\end{array}$ \\
\hline \multirow[t]{3}{*}{ N. helminthorum } & Ceratoppia sp. & Liacaroidea & Moniez (1887) \\
\hline & Ceratoppia bipilis & Liacaroidea & Dissanaike (1958) \\
\hline & Xenillus tegeocranus & Liacaroidea & Dissanaike (1958) \\
\hline N. hermanniae & Hermannia gibba & Hermannioidea & Purrini et al. (1979) \\
\hline N. ptyctimae & Rhysotritia ardua & Phthiracaroidea & $\begin{array}{l}\text { Purrini and Bäumler } \\
\text { (1976) }\end{array}$ \\
\hline N. sperchoni & Sperchon sp. & Sperchontidae & Lipa (1962) \\
\hline N. steganacari & Steganacarus striculus & Phthiracaroidea & $\begin{array}{l}\text { Purrini and Weiser } \\
\text { (1981) }\end{array}$ \\
\hline
\end{tabular}


Table 4 Continued

\begin{tabular}{|c|c|c|c|}
\hline N. steinhausi & Tyrophagus putrescentiae & Tyroglyphidae & Weiser (1956) \\
\hline $\begin{array}{l}\text { Oligosporidium } \\
\text { occidentalis }\end{array}$ & Metaseiulus occidentalis & Phytoseiidae & $\begin{array}{l}\text { Becnel, Jeyaprakash, } \\
\text { Hoy, and Shapiro } \\
\text { (2002) }\end{array}$ \\
\hline Pleistophora cephei & Cepheus dentatus & Cepheoidea & $\begin{array}{l}\text { Purrini and Weiser } \\
\text { (1981) }\end{array}$ \\
\hline P. dindali & Carabodes coriaceus & Carabodidae & $\begin{array}{l}\text { Purrini and Weiser } \\
\text { (1981) }\end{array}$ \\
\hline P. platynothri & Platynothrus peltifer & Nothroidea & $\begin{array}{l}\text { Purrini and Weiser } \\
\text { (1981) }\end{array}$ \\
\hline \multirow[t]{6}{*}{ P. oribatei } & Carabodes femoralis & Carabodidae & $\begin{array}{l}\text { Purrini and Weiser } \\
\text { (1981) }\end{array}$ \\
\hline & Damaeus clavipes & Damaeidae & $\begin{array}{l}\text { Purrini and Weiser } \\
\text { (1981) }\end{array}$ \\
\hline & Microtritia minima & Euphthiracaroidea & $\begin{array}{l}\text { Purrini and Weiser } \\
\text { (1981) }\end{array}$ \\
\hline & Phthiracarus piger & Phthiracaroidea & $\begin{array}{l}\text { Purrini and Weiser } \\
\text { (1981) }\end{array}$ \\
\hline & Phthiracarus sp. & Phthiracaroidea & $\begin{array}{l}\text { Purrini and Weiser } \\
\text { (1981) }\end{array}$ \\
\hline & Physotritia duplicata & Phthiracaroidea & $\begin{array}{l}\text { Purrini and Weiser } \\
\text { (1981) }\end{array}$ \\
\hline $\begin{array}{l}\text { Thelohania } \\
\text { microtritiae }\end{array}$ & Microtritia minima & Euphthiracaroidea & $\begin{array}{l}\text { Purrini and Weiser } \\
\text { (1981) }\end{array}$ \\
\hline
\end{tabular}

The above classification is still being used, but we know now on the basis of ribosomal RNA gene sequencing that various groups in the Flagellata and Rhizopoda are not closely related. There may be greater genetic difference between two groups of Flagellata than between flowering plants and vertebrates. In modern classification, the following seven phyla are distinguished: Apicomplexa, Sarcomastigophora, Microspora, Ciliophora, Acetosphora, Myxospora and Labyrinthomorpha. It is not within the scope of this chapter to go into details about this classification.

Two phyla of the subkingdom Protozoa, the Apicomplexa and the Microspora, have members that are found in arthropods. Some of these are also pathogens of vertebrates, while others are commensals or weak pathogens; sometimes, they are highly virulent and pathogenic organisms (cf. Tanada \& Kaya, 1993).

Protozoa associated with mites are mainly found in the Apicomplexa, with the classes Gregarina and Coccidia, and in the phylum Microspora. The class Gregarina is divided into the orders Eugregarinida and Neogregarinida. Several members of the former order have been detected in mites. 
The phylum Microspora also contains several pathogens of mites. Table 4 lists protozoan species that have hitherto been isolated from mites. There is little information available on the population dynamical effects of these organisms on natural mite populations.

\subsection{Apicomplexa Infections in Mites}

Apicomplexans have very complex life cycles, with much variation among the different apicomplexan groups. Both asexual and sexual reproduction is involved, although some Apicomplexa skip one or the other stage. The life cycle starts when an infective stage, the sporozoite, enters a host cell, and then divides repeatedly to form numerous merozoites. Some of the merozoites transform into sexually reproductive cells, or gamonts. These gamonts join together in pairs and form a gamontocyst. Within the gamontocyst, the gamonts divide to form numerous gametes. Pairs of gametes then fuse to form zygotes, which give rise by meiosis to new sporozoites, and the cycle starts all over again.

Apicomplexa are transmitted to new hosts in various ways; some, like the malaria parasite, are transmitted by infected mosquitoes, while others may be transmitted in the feces of an infected host, or when a predator eats infected prey.

Gregarinia, or gregarines have mature gamonts (trophozoites) that are large and extracellular. The gamonts are found in the digestive tract and body cavities of invertebrates and they possess organelles (see Tanada \& Kaya, 1993). They have usually similar gametes (isogametes) and undergo syzygy: mature gamonts detach themselves from the midgut and line themselves end to end in pairs or in large numbers to form a prenuptial association. The zygotes form oocysts within gametocysts. Eugregarines have a life cycle that consists only of gametogony and sporogony, but the neogregarines, considered more primitive, have an additional schizogony (a multiple fission process). This schizogony (or merogony) occurs intra- or extracellularly and causes the presence of larger numbers of the pathogen than in case of the eugregarines. These higher numbers result in a more virulent infection.

As early as 1885, the eugregarine Gregarina oribataram was reported in an unidentified mite (see Lipa, 1971). Unidentified gregarine infections were observed in the oribatids Damaeus oblongus and D. geniculatus (Damaeidae) by Michael in 1884 and Wellmer in 1911 (see Lipa, 1971). Gregarina scutovertexi was described by Erhardová in 1955 from Scutovertex minutus, an oribatid mite that serves as vector of the tape worm Monieza expansa. Several other eugregarine species were described by Purrini et al. (1979) and Purrini and Ormiers (1981). For more details is referred to Table 4.

An interesting eugregarine infection was also noted in the intestinal wall of the water mite Limnochares aquatica (Hydrachnellidae) (see Issi \& Lipa, 1968), while Gregarina euzeti was detected in the oribatid Euzetes seminulum (Lipa, 1982). Despite all these reports on gregarines, no data are available on the impact of these infections on the host. It is generally believed that gregarines are of low virulence. 
Coccidia differ from the gregarines in their gamogony: female gamonts of gregarines give rise to a number of gamonts whereas those of Coccidea only to single gamonts. One coccidian species has been described from an oribatid (Purrini, 1984).

\subsection{Microspora Infections in Mites}

Microspora (or Microsporidia) are obligate intracellular parasites with a broad host range including all animal groups. They rank among the smallest eukaryotes $(1-40 \mu \mathrm{m})$ with the shortest eukaryotic genome and are generally considered to be a separate phylum within the subkingdom Protozoa. However, recent molecular studies indicate that they may be considered to be extremely reduced fungi. Replication takes place within the host's cells, which are infected by means of unicellular spores.

Microsporidia are unusual in lacking mitochondria and in having mitosomes. ${ }^{4}$ They also lack motile structures such as flagella. The spores are protected by a layered wall made of proteins and chitin. Their interior is dominated by a unique coiled structure called the polar filament. Spores, the infective stage, are ingested by the host and, in the midgut, their polar filament is instantaneously emitted as turning a garden hose inside out. The polar tube penetrates the host cell and the contents of the spore are pumped through it without destruction of the host cell. Within the host cell, an increase in numbers followed by the development into new spores takes place. In this way, the infection spreads throughout the host. Many different tissues may be affected. The spores may be released into the environment during the life of the host or after its death. The spores are the only stages that can survive outside the host. Many microsporidia have very complex life cycles with several spore types and host involved. Microsporidiosis is often transmitted vertically (from mother to offspring), usually without spores as intermediary. Vertical transmission may be transovarial, by passage though the ovary, or transovum, a form of transovarial transmission in which the pathogen enters the egg while it is still in the ovary.

Taxonomy was in the past mainly based on spore size and shape. These characters are, however, unsatisfactory and for that reason, ultrastructural characteristics have been used. This has caused a considerable revision in this group of pathogenic organisms (Sprague, Becnel, \& Hazard, 1992). Recently, several research groups have started to integrate molecular techniques for phylogenetic studies of Microsporidia. This will undoubtedly result in a new revision of these taxa.

The first microsporidium described in mites was Nosema steinhausi (Weiser, 1956) from the stored product mite Tyrophagus putrescentiae (Tyroglyphidae). The disease affects both adults and nymphs. Experiments in a colony of the mite showed that the disease progressed from about $10 \%$ infection at the start of the experiment to

\footnotetext{
${ }^{4} \mathrm{~A}$ mitosome is an organelle found in some unicellular eukaryotic organisms. The mitosome has only recently been found and named, but its function has not yet been well characterized. It is sometimes termed a crypton.
} 
$75 \%$ after 2 months. The colony was completely eradicated after a further 2 weeks. Several other authors have described microporidia from various species of mites. For more details refer to Table 4.

In the late 1980s poor performance was noted of phytoseiids used as biological control agent for thrips and spider mites in greenhouse crops and this observation has led to studies on the possible involvement of pathogens in predator colonies. Beerling and Van der Geest (1991a, 1991b) studied a microsporidosis in mass cultures of the predators Amblyseius barkeri and Neoseiulus cucumeris (Phytoseiidae) that are being used for the control of the thrips pests Frankliniella occidentalis and Thrips tabaci (Thripidae) on vegetable and ornamental crops in greenhouses. Diseased predators show a low reproduction and predation capacity of the mites unsatisfactory. Predatory mites were sluggish in their movement and had a swollen and whitish appearance (Beerling \& Van der Geest, 1991a).

The presence of numerous spores could be detected in squash preparations of the mites and it was assumed, that the pathogen involved belonged to the Pleistophoridae (Microspora). Also infected stored product mites were observed. Further work showed that three different spore types are found in the predator cultures. It is difficult to say that three species of Microsporidia are involved, since some species have several spore types during their life cycle. Recently, a new species of a microsporidium parasite, Intexta acarivora, was observed in the gut epithelium of the forage mite T. putrescentiae (Larsson et al., 1997), obtained from a commercial culture in The Netherlands. Mites of this culture are used as prey for a commercial rearing of $N$. cucumeris.

Beerling and Van der Geest (1991a, 1991b) also studied infected mite strains from a commercial rearing in The Netherlands, but it is not known whether this has the same origin as the samples studied by Larsson et al. (1997). The spore size values of this microsporidium do not correspond with any of the values of the spores in Beerling, Rouppe van der Voort, and Kwakman (1993).

Bjørnson et al. (1996) studied colonies of $P$. persimilis that were obtained from suppliers of biological control agents. On the basis of spore morphology, three distinct microsporidia could be observed in strains of $P$. persimilis, obtained from three different suppliers. The ultrastructure of the pathogen and the course of the disease of a colony obtained from Europe were studied in more detail. Schizonts were observed inside the nuclei of the digestive cells of the ventriculus and within the protoplasm of cells that line the caecal wall and the muscle tissue underlying it. The properties of the pathogen made it difficult to assign it to an existing genus. For that reason, it was placed in the collective group Microsporidium. Vertical transmission for this microsporidium was proven, as mature spores were observed in developing eggs inside gravid females (Fig. 11). The performance of an infected colony was greatly affected (Bjørnson \& Keddie, 1999): mean fecundity and prey consumption of infected mites were significantly reduced. Short-term survivability was variable and was not a good measure of predator quality. However, uninfected females lived longer than infected females. 


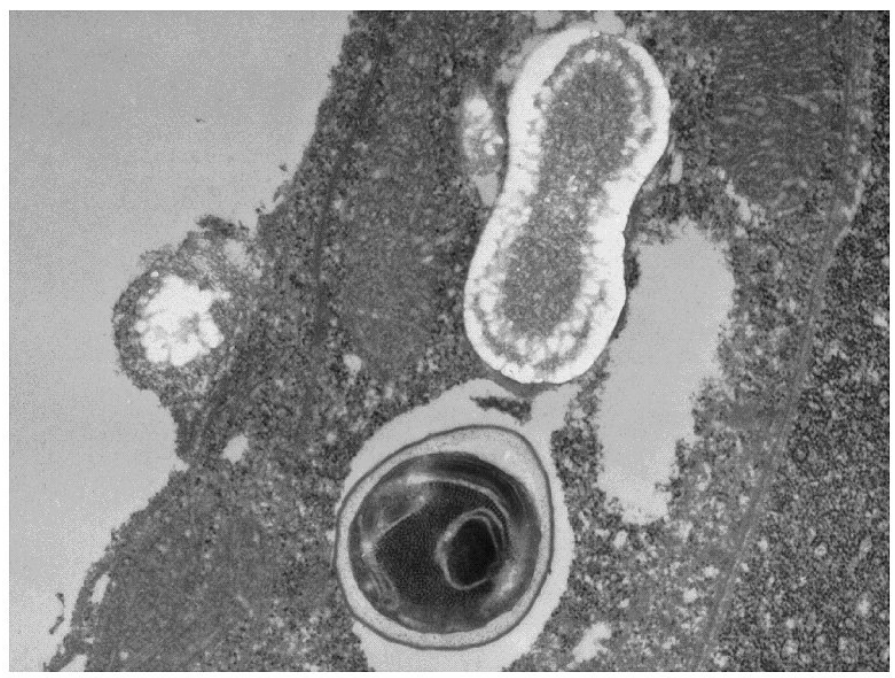

Figure 11. Cross section of a microsporidian spore and a crystal of Phytoseiulus persimilis. The polar filament of the spore is not visible. Photograph by Dr. Susan Bjørnson.

Poor performance of the predators, due to the presence of pathogens in the mass cultures is a threat to integrated pest management in especially glasshouse crops (e.g. Steiner, 1993). It is clear that more attention should be paid to a good monitoring system. The presence of pathogens should be established early in the manufacturing process, which requires a fast and reliable detection method. In the past, visual inspection with the aid of a binocular or compound microscope was the only way to establish the presence of these pathogens. A polarizing filter is needed to avoid confusion with the birefringent crystals that are commonly present inside adult phytoseiids (see Section 6.1).

The availability of a method to detect the disease at an early stage is of great importance for the commercial production of natural enemies. Beerling et al. (1993) developed an ELISA to detect the presence of microsporidiosis in predator massrearings. Monoclonal antibodies were produced against one spore type (oblong), that was present in both prey and predator species. A next step would be the use of more sensitive molecular techniques which makes the detection of microsporidiosis possible regardless of spore type, and even before spores are formed (Malone \& McIvor, 1996).

Recently, a new species of microsporidia was described by Becnel, Jeyaprakash, Hoy, and Shapiro (2002) from the predatory mite Metaseiulus occidentalis. Mites infected with Oligosporidium occidentalis do not show any external or gross signs of infection, but electronmicroscopical analysis reveales that the pathogen develops in eggs, larvae, nymphs and adults of the predator. Mature cells of $O$. occidentalis can be found in cecal cells, lyrate organ cells, ganglia, epithelial cells, muscle, inside the ovary and in developing and mature eggs. Female predators have in general a shorter 
life span, a low oviposition rate and fewer female progeny. No effect could be shown on longevity of males or on male progeny survival to larval and adult stages.

The infection may affect the performance of the predator. Heat treatments of infected colonies had some success: eggs placed for 7 days in a chamber at $33^{\circ} \mathrm{C}$ and subsequently at $27^{\circ} \mathrm{C}$ showed a reduced infection rate, but the disease was still not completely eliminated. Mites emerging from these eggs still showed spores inside their body, but it was assumed that most of these spore were dead as the majority of the mites survived. After a number of weeks, infection rates were again high, indicating that the heat treatment was only partially effective. However, when eggs were placed at $33^{\circ} \mathrm{C}$. and when their progeny was also kept at this temperature, disease-free mites were obtained. It was also shown that the disease may be horizontally transmitted, probably by cannibalism.

At this moment, no other cure exists for microsporidiosis in predatory mite mass rearings. Anti-microsporidial compounds, such as albendazole, fumagillin, metronidazole and nifedipine were not successful in eliminating microsporidiosis in mass cultures of $P$. persimilis (Bjørnson, 1998). Therefore, efforts should be made to keep the starting cultures of predatory mites disease-free. Heat treatment of infected eggs, or rearing infected individuals at elevated temperatures, has been shown to reduce disease prevalence in some cases; however, the most effective and practical means for rearing microsporidian free predatory mites is to start a new rearing with progeny from uninfected females.

\section{OTHER DISEASES}

\subsection{Symptoms Ascribed to Poor Condition}

In this chapter, we discuss a condition in mites that cannot be ascribed to the action of a pathogen. In a number of instances, rectal plugs, usually in combination with abdominal discoloration have been observed in phytoseiids (Tanigoshi, Fagerlund, \& Nishio-Wong, 1981; Bjørnson et al., 1997). This discoloration is usually manifested as two white stripes along the dorsal sides of the body within the Malpighian tubules. The condition is frequently found in laboratory colonies of predatory mites and it may be a sign of poor condition of the predator. Tanigoshi (1982), for example, considered the condition a sign of senescence. Affected mites are often lethargic and have frequently numerous densely packed, birefringent dumbbell-shaped bodies, mainly in the Malpighian tubules, rectum and anal atrium.

In Cheyletus eruditus, abdominal discoloration is also associated with the occurrence of birefringent crystals in the excretory organs, especially when reared under crowded conditions. These crystals are considered to be the normal excretory products (Hughes, 1950) and probably consist of guanine and uric acid (McEnroe, 1961). These compounds are insoluble and are probably stored in the malpighian tubes prior to excretion. The crystals observed in $P$. persimilis, however, contain high levels of potassium, low levels of phosphorous and sulphur and traces of chlorine, very unlike the common waste products mentioned above (Bjørnson, 1998). Large numbers of crystals in mites are especially found in laboratory mites, 
reared under crowded condition (Fig. 12), and it is assumed that they are an indication of a poor condition of the mites.

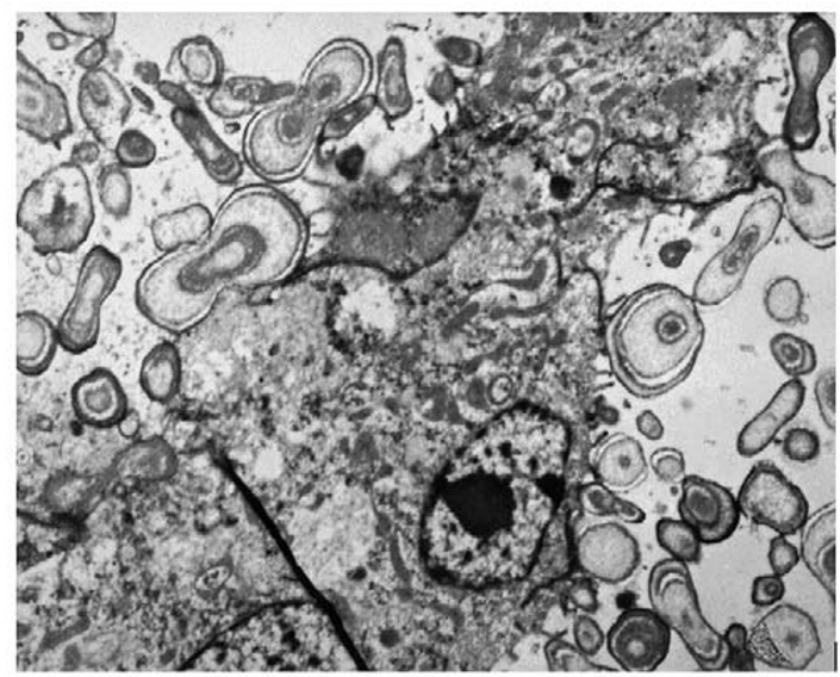

Figure 12. Crystals in tissue of Phytoseiulus persimilis. Such crystals are often an indication of a poor condition of the mite. Photograph of Dr. Susan Bjørnson.

\subsection{Identification of Pathogens}

Recognition of an organism causing disease in noxious mites will aid in the process of implementing control strategies against such mites, while it will also be of great importance to know disease causing organisms in mites that are mass reared for biological control purposes. However, identification of pathogens is not in all instances easy: for example, virus recognition in diseased mites may require very comprehensive research before one may decide that a virus is the disease causing agent. In contrast to insects, very few viruses have been isolated from mites and the viruses known to cause disease in mites are not as readily identifiable as some of the insect viruses. A large number of insect viruses belong to the baculoviruses, rodshaped viruses that may form large inclusion bodies (polyhedra) in the cell nuclei (nuclear polyhedrosis viruses), or smaller so-called granula (granulosis viruses). Other viruses, the cytoplasmic polyhedrosis viruses are icosahedra and are also included in large inclusion bodies of irregular form. Identification of such viruses can partially be done by light-microscopic means, in combination with more sophisticated molecular techniques. Such viruses are not known from Acari. Hitherto, only few viruses have been identified as pathogen of mites.

Bacteria causing disease are often obligate intracellular organisms. Classical identification based on characters such as nutrient requirement and structure of colonies on artificial media is not possible as these bacteria cannot be grown outside it host's cell. However, the availability of molecular techniques has made 
identification of such intracellular bacteria possible by, among others, analysis of $16 \mathrm{~S}$ rDNA gene sequences. The best-known species of such intracellular bacteria belong to the genus Wolbachia, probably the most widely-spread parasitic bacterium known. Abnormal sex ratios, incompatibilities between strains of mites and absence of male offspring may point to the presence of Wolbachia sp. or other symbionts. Feeding infected mites with antibiotics may remove these parasitic bacteria and will result in "normal" offspring. Molecular analysis of 16S rDNA will finally prove the presence of Wolbachia or other intracellular bacteria.

The largest number of pathogens of mites is found in the fungi. Pathogens of mites are mainly found in the Zygomycota and Deuteromycota (or Fungi Imperfecti). For a proper identification, it is usually necessary to study sporulating fungi. This can be accomplished by incubating the infected mites under conditions of a high relative humidity.

Zygomycota are characterized by the absence of cross walls (septa) in their hyphae and the presence of tick-walled, sexual spores (zygospores). However, the primary taxonomic emphasis is on asexual reproductive structures. The asexual spores (conidia) are released from the conidiophores by force and form often a halo around the host's cadaver. Species infecting mites form secondary conidia upon germination of these conidia. The secondary conidium is much smaller in size and is called capilliconidium. Identification to the species is often difficult and requires the aid of specialists. Of some species, only zygospores (or resting spores) are known. Taxonomy of these species is mainly based on the properties of these spores. These species have been lumped together in the genus Tarichium.

Several Deuteromycetes have been isolated from Acari, belonging to the following genera: Aspergillus, Beauveria, Cephalosporium, Hirsutella, Paecilomyces, Sporothrix, Tolypocladium and Lecanicillium (Verticillium). A key to the genera of Deuteromycetes infecting insects and mites can be found in Samson (1981). Identification requires examination of conidium ontogeny which is the primary character for typifying the different genera. There are two modes of blastic conidiogenesis: phialidic and sympodal. A succession of conidia is produced by a phialidic conidiogenous cell. The shape of the phialide is dependent on the genus: flask-like in Paecilomyces and Hirsutella, awl-like in Lecanicillium and cylindrical in Metarhizium. The conidia are produced in chains (Paecilomyces, Metarhizium), or they are contained in slimy heads or droplets (Lecanicillium, Fusarium). Phialides of Hirsutella form conidia that are held together in a slimy sheath. This gives the impression that only one conidium is being produced. Sympodial development is observed in species of the genera Beauveria and Sporothrix. Conidia are formed singly on a laterally proliferating conidiogenous cell that often shows a geniculate or zigzag type of elongation. For more details is referred to Samson (1981).

\section{PROSPECTS OF ACAROPATHOGENS FOR INTEGRATED PEST MANAGEMENT}

Comprehensive research has been conducted to study the possibilities to use pathogens for the control of insects and other invertebrate pests. There are several cases known how pathogens may decimate populations of phytophagous mites under 
natural conditions. An early example is a virus disease of the citrus red mite in citrus groves throughout California and Arizona (Reed, 1981). However, successful application of the virus failed for a variety of reasons. Mass production of the virus is difficult as the virus can only be grown in living mites. This fact makes mass production very laborious and expensive. Furthermore, the virus becomes rapidly inactivated by sunlight when applied in aqueous formulations, while high temperatures, common in citrus orchards in California and Arizona, also have a negative effect on the virulence of the virus. Inactivation of the virus by sunlight may be overcome by the addition of ultraviolet protecting substances. The main reason that this virus, although very host specific, has never been successful are the difficulties encountered during mass production. Biological acaricides with viruses as active ingredient are not foreseen for the near future, as few viruses of phytophagous mites are known. The situation with respect to the varroa mite Varroa jacobsoni may be completely different. Several viruses have been isolated from this parasitic mite and more research may lead to the discovery of viruses that could be used for the control of the varroa mite. A point to worry about is that the varroa mite may act as vector of honey bee viruses. Host specificity experiments are for that reason of great importance.

Many fungal pathogens show a high pathogenicity towards phytophagous mites. There are several examples showing how fungi are able to cause large epidemics in natural populations of tetranychids and eriophyids. One of the main obstacles for a successful application of fungal pathogens for the control of invertebrate pests in agricultural crops is the ambient condition within the vegetation. Almost all fungi require a relative humidity near the saturation point for both spore germination and spore formation. Entomophthorales epidemics have frequently been observed in insect and mite populations: Neozygites floridana is a fungal pathogen that may cause large reductions in population sizes of several species of spider mite. Such epidemics usually occur later in the season, when population sizes of spider mites are large and when relative humidity is near the saturation point. Damage to the crop has then already been inflicted.

Experiments have been conducted to advance epidemics by inundative releases of the pathogen. The high virulence against certain target pests and their high specificity make these fungi attractive for inundative releases. However, entomophthoralean species are very fastidious: culturing and sporulation in artificial media is hardly possible which makes mass production of these fungi very expensive and laborious, as they should be grown in living mites. In addition, the infective stages of these fungi are rather short-lived and this characteristic makes their application difficult. It has been suggested that the use of these fungi in greenhouses may show good prospects (Maniania, Bugeme, Wekesa, Delalibera, \& Knapp, 2008).

In many greenhouses, high value horticultural crops are grown where environmental coniditions that normally favor the efficacy of these fungi can easier be manipulated than in outdoor crops. In addition, horizontal transmission of the fungus may be more efficient when spider mites densities are sufficiently high, making repeated inundative releases unnecessary. However, low spider mite densities would be an disadvantage for successful control of the pest concerned. 
From the other hand, classical biological control with these fungi seems to be attractive in certain circumstances. Efforts have been made to use Neozygites tanajoae as a control agent for the cassava green mite in Africa by releasing the fungus in cassava fields in Benin as a classical biological control agent. The fungus has later been isolated from the release areas where it caused a higher mortality among cassava mites than the local strains of $N$. tanajoae did. However, more knowledge is required. We know too little how the fungus overcomes unfavorable periods, about the role of resting spores and under which conditions may resting spores sporulates. Interesting observations were made by Elliot et al. (2008) in a cassava field in the state on Bahia, Brazil. Epidemics of the fungus were virtually absent when cassava green mite populations reached high densities, as not sufficient fungus inoculum was present. Later in the season, sufficient fungus inoculum was observed, but at that time no mites were present due to defoliation of the cassava plants. It is very hard to manipulate such a system, as mass production, followed by inundative releases is impossible at a large scale.

The fungus does not seem to be the solution for the cassava green mite problem in Africa, although it is promising that the fungus seems to become established in the release areas. The fungus may be an important factor in the control of the cassava mite, when applied in combination with predatory mites. A point of concern is also the use of chemical pesticides: it is known that, in particular fungicides may have a detrimental effect on the fungal pathogen. Careful selection of chemicals used in a crop system is of utmost importance.

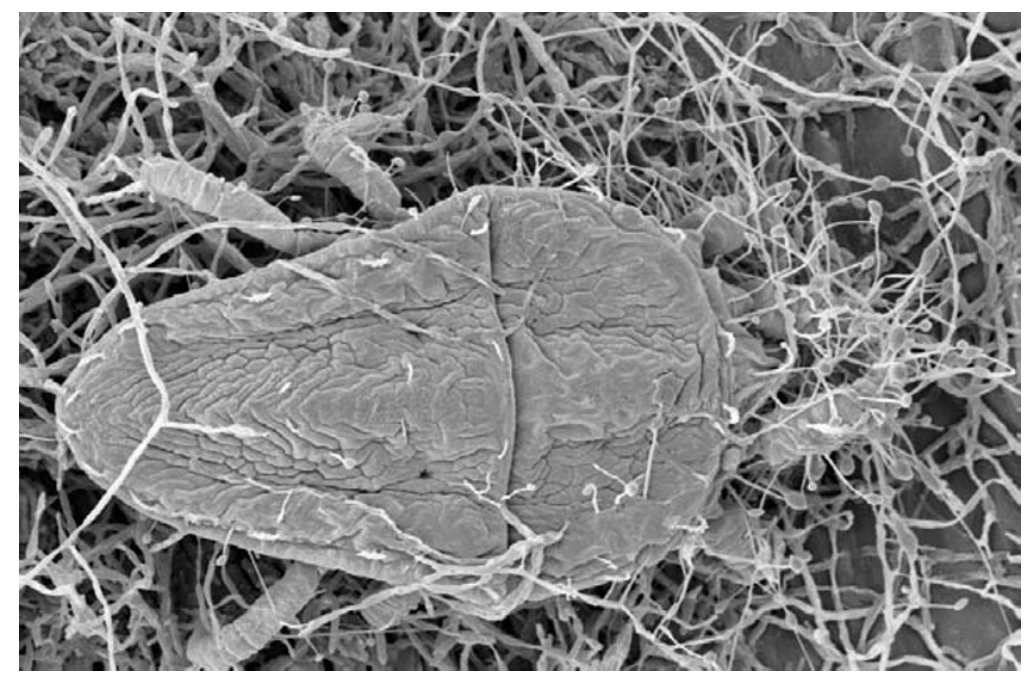

Figure 13. Brevipalpus phoenicis infected by Lecanicillium (Verticillium) lecanii. Photograph courtesy of Dr. Marcel Tanzini.

Several Deuteromycota are known with a high virulence towards mites and other invertebrates. This group of fungi can in general be grown in artificial media and mass production is therefore no problem. The first attempt to control an 
invertebrate pest with a fungus of this group was already conducted in Russia in 1888, when Krassilstschik sprayed a suspension of spores of Metarhizium anisopliae in the field for the control of the sugar beet curculio Cleonis punctiventris ( $c f$. Steinhaus, 1949). Since then, many attempts have been made to formulate mycopesticides, mainly for the control of insect pests (De Faria \& Wraight, 2007).

Until now, 171 products have been developed worldwide with entomo- and acaropathogens as active ingredients. Of these, 129 products are still available. The number of products that have been developed for use against mites is small: only 17 products are recommended for use against Acari. The main part of these pesticides contains $B$. bassiana as active ingredient, but four preparations are based on Lecanicillium sp. (formerly Verticillium lecanii) (Fig. 13). Many of these species have a broad host spectrum, like Beauveria bassiana and Metarhizium anisopliae. The genus Hirsutella contains several members with a high specificity towards mites. The best studied species is $H$. thompsonii, originally described from the citrus rust mite Phyllocoptruta oleivora. Acaricidal preparations with $H$. thompsonii as active ingredient were developed in the 1980s for the control of the citrus rust mite, but the production was discontinued because of instability of the product. It is hopeful to notice that the interest in the production of $H$. thompsonii based acaricides has recently been renewed in India, and in some Latin American countries, but now for the control of rust mites in coconut. This renewed interest has led in India to the production of a successful bio-acaricide.

In Colombia, biopesticides have been developed that contain a mixture of invertebrate pathogens, e.g. Microbiol Completo contains B. bassiana, $M$. anisopliae, Nomuraea rileyi, Isaria fumosorosea and B. thuringiensis. It is recommended for the control of a variety of insect species and Acari. It is remarkable that in particular in Latin American countries, many bioinsecticides are being developed with fungal pathogens as active ingredients. The climatic conditions may be more suitable for the applications of such pesticides than, e.g. in Europe. As mentioned earlier, a major drawback in the use of fungi is their dependence on a high relative humidity during spores germination. Oily formulations seem to be a solution to this problem. Oily substances protect the spores against desiccation and allow sporulation at a somewhat lower relative humidity.

Hirsutella thompsonii var. synnematosa has been introduced from Zimbabwe and $H$. thompsonii var. vinacea from North Carolina as classical biological control agents for the control of Eriophyes sheldoni and Phyllocoptruta oleivora in Argentina. Infection levels after release were high, but no information is available about their persistence. The project has been discontinued ( $c f$. Maniania et al., 2008).

A point of major concern in integrated control programs is the quality of biological control agents. Predatory mites have been used for several decades for the control of spider mites in horticultural and agricultural crops. Low performance of predators has revealed the presence of pathogens. For reviews is referred to Schütte and Dicke (2008), Bjørnson (2008) and Hoy and Jeyaprakash (2008). Microspora species have been causing problems in mass cultures of several species of Phytoseiidae, in particular Amblyseius barkeri and A. cucumeris, but they are also known to occur in Phytoseiulus persimilis and Metaseiulus occidentalis. Sanitary 
measures and careful selection of uninfected lines of predatory mites are still the only solution to these problems. Acaricomes phytoseiuli is a bacterium that affects the behavior and predacious capacity of $P$. persimilis. This bacterium has not yet been encountered in mass rearings for the predator, but it will be clear that screening for such pathogens is necessary. Another group of bacteria that can cause considerable damage in mass cultures of beneficial mites and insects are Wolbachia sp., Cardinium sp., Spiroplasma sp. and other bacteria that affect sex ratios and that may cause incompatibilities between strains of the same species. This type of bacteria is widespread in mites and other vertebrates

\section{REFERENCES}

Agudela-Silva, P. (1986). A species of Triplosporium (Zygomycetes: Entomophthorales) infecting Mononychellus progressivus (Acari: Tetranychidae) in Venezuela. Florida Entomologist, 69, 444-446.

Aksoy, H. M., Ozman-Sullival, S. K., Ocal, H., Celik, N., \& Sullivan, G. T. (2008). The effects of Pseudomonas putida biotype B on Tetranychus urticae (Acari: Tetranychidae). Experimental and Applied Acarology, 46, 223-230.

Alves, S. B., Tamai, M. A., \& Lopes, R. B. (1998). Avaliação de Beauveria bassiana (Bals.) Vuill. para controle de Tetranychus urticae Koch em crisântemo. Abstracts 17th Brazilian Congress of Entomology, Rio de Janeiro, 1068 (abstract).

Baker, J. R., \& Neunzig, H. N. (1968). Hirsutella thompsonii as a fungus parasite of the blueberry mite. Journal of Economic Entomology, 61, 1117-1118.

Bałazy, S. (1973). A review of entomopathogenic species of the genus Cephalosporium Corda (Mycota, Hyphomycetales). Bulletin de la Société des Amis des Sciences et des Lettres de Poznań, 14, 101-137.

Bałazy, S., \& Wiśniewski, J. (1982a). Two species of entomopathogenic fungi on the myrmecophilic mite Trachyuropoda coccinea (Michael, 1891) (Acari: Uropodina). Bulletin de l'Academie Polonaise des Sciences, Série Sciences Biologiques, 30, 81-84.

Bałazy, S., \& Wiśniewski, J. (1984). Records on some lower fungi occurring on mites (Acarina) from Poland. Acta Mycologica, 20, 159-172.

Bałazy, S., \& Wiśniewski, J. (1989). Pathogene Pilze bei Milben. Mikrokosmos, 78, 299-304.

Bałazy, S., Wiśniewski, J., \& Kaczmarek, S. (1987). Some noteworthy fungi occurring on mites. Bulletin of the Polish Academy of Sciences, Biological Sciences, 35, 199-224.

Bałazy, S., Mietkiewski, R., Tkaczuk, C., Wegensteiner, R., \& Wrzosek, M. (2008). Diversity of acaropathogenic fungi in Poland and other European countries. Experimental and Applied Acarology, 46, 53-70.

Bartkowski, J., Odindo, M. O., \& Otieno, W. A. (1988). Some fungal pathogens of the cassava green spider mite Mononychellus spp. (Tetranychidae) in Kenya. Insect Science and its Application, 9, 457-459.

Becnel, J. J., Jeyaprakash, A., Hoy, M. A., \& Shapiro, A. (2002). Morphological and molecular characterization of a new microsporidian species from the predatory mite Metasiulus occidentalis (Nesbitt) (Acari: Phytoseiidae). Journal of Invertebrate Pathology, 79, 163-172.

Beerling, E. A. M., Rouppe van der Voort, J. N. A. M., \& Kwakman, P. (1993). Microsporidiosis in mass rearings of predatory mites: Development of a detection method. Proceedings of the Section Experimental and Applied Entomology of the Netherlands Entomological Society (NEV, Amsterdam), 4, 199-204.

Beerling, E. A. M., \& Van der Geest, L. P. S. (1991a). Microsporidiosis in mass-rearings of the predatory mites Amblyseius cucumeris and A. barkeri (Acarina: Phytoseiidae). Proceedings of the Section Experimental and Applied Entomology of the Netherlands Entomological Society (NEV, Amsterdam), 2, 157-162.

Beerling, E. A. M., \& Van der Geest, L. P. S. (1991b). A microsporidium (Microspora: Pleistophoridae) in mass-rearings of the predatory mites Amblyseius cucumeris and A. barkeri (Acarina: Phytoseiidae): Analysis of a problem. IOBC/WPRS Bulletin, 14, 5-8.

Berliner, E. (1915). Ueber die Schlaffsucht der Mehlmottenraupe (Ephestia kuhniella Zell) und ihren Erreger Bacillus thuringiensis n. sp. Zeitschrift für Angewandte Entomologie, 2, 29-56. 
Bjørnson, S. E. (1998). Morphology and pathology of the predatory mite, Phytoseiulus persimilis AthiasHenriot (Acari: Phytoseiidae). PhD Thesis, University of Alberta, Edmonton, AB, Canada, 232pp.

Bjørnson, S. (2008). Natural enemies of mass-reared predatory mites (family Phytoseiidae) used for biological control. Experimental and Applied Acarology, 46, 299-306.

Bjørnson, S., \& Keddie, B. A. (1999). Effects of Microsporidium phytoseiuli (Microspora) on the performance of the predatory mite, Phytoseiulus persimilis (Acari: Phytoseiidae). Biological Control, $15,153-161$.

Bjørnson, S., Steiner, M. Y., \& Keddie, B. A. (1996). Ultrastructure and pathology of Microsporidium phytoseiuli n. sp. infecting the predatory mite, Phytoseiulus persimilis Athias-Henriot (Acari: Phytoseiidae). Journal of Invertebrate Pathology, 68, 223-230.

Bjørnson, S., Steiner, M. Y., \& Keddie, B. A. (1997). Birefringent crystals and abdominal discoloration of the predatory mite Phytoseiulus persimilis (Acari: Phytoseiidae). Journal of Invertebrate Pathology, 69, 85-91.

Boekhout, T., Theelen, B., Houbraken, J., Robert, V., Scorzetti, G., \& Gafni, A., et al. (2003). Novel anamorphic fungi belonging to the Ustilagomycetes: Meira geulakonigii gen. nov., sp. nov., Meira argovae sp. nov. and Acaromyces ingoldii gen. nov., sp nov. International Journal of Systematic and Evolutionary Microbiology, 53, 1655-1664.

Brandenburg, R. L., \& Kennedy, G. G. (1982). Relationship of Neozygites floridana (Entomophthorales: Entomophthoraceae) to twospotted spider mite (Acari: Tetranychidae) populations in field corn. Journal of Economic Entomology, 75, 691-694.

Brandenburg, R. L., \& Kennedy, G. G. (1983). Interactive effects of selected pesticides on the twospotted spider mite and its fungal pathogen Neozygites floridana. Entomologia Experientia et Applicta, $34,240-244$.

Breeuwer, J. A. J., \& Jacobs, G. (1996). Wolbachia: Intracellular manipulators of mite reproduction. Experimental and Applied Acarology, 20, 421-434.

Bridge, P. D., \& Worland, M. R. (2004). First report of and entomophthoralean fungus on an arthropod host in Antarctica. Polar Biology, 27, 190-192.

Bridge, P. D., \& Worland, M. P. (2008). An association between the Antarctic mite Alaskozetes antarcticus and an entomophthoralean fungus of the genus Neozygites. Experimental and Applied Acarology, 46, 43-52.

Bugeme, D. M., Maniania, N. K., Knapp. M., \& Boga, J. J. (2008). Effect of temperature on virulence of Beauveris bassiana and Metarhizium anissopliae solates to Tetranychus evansi, Experimental and Applied Acarology, 46, 275-285.

Cabrera, R. I, Caceras, I., \& Dominguez, D. (1987). Estudios de dos especos de Hirsutella y sus hospedantes en el cultivo de la guayaba, Psidium guajava. Agrotecnia de Cuba, 19, 29-34.

Cabrera, R. I., \& Domínguez, D. (1987a). Hirsutella nodulosa y Hirsutella kirchner: Dos nuevos hongos patógenos del ácaro del moho, Phyllopcoptruta oleivora. Ciencia y Tecnica en la Agricultura, Proteccion de Plantas, 10, 139-142.

Cabrera, R. I., \& Domínguez, D. (1987b). El hongo Hirsutella nodulosa, nuevo parásito para el ácaro del cocotero Eriophyes guerreronis. Ciencia y Tecnica en la Agricultura, Cítricos y Otros Frutales, 10, 41-51.

Cabrera, R. I., \& McCoy, C. W. (1984). El acaro Vasates detructor nievo hospedero del hongo Hirsutella thompsonii. Ciencia y Tecnica en la Agricultura, Proteccion de Plantas, 7, 69-79.

Carner, G. R. (1976). A description of the life cycle of Entomophthora sp. in the two-spotted spider mite. Journal of Invertebrate Pathology, 28, 245-254.

Carner, G. R., \& Carnerday, T. D. (1968). Field and laboratory investigations with Entomophthora fresenii, a pathogen of Tetranychus spp. Journal of Economic Entomology, 61, 956-959.

Cehrnin, L., Gafni, A., Mozes-Koch, R., Gerson, U., \& Sztejnberg, A. (1997). Chitolytic activity of the acaropathogenic fungi Hirsutella thompsonii and Hirsutella necatrix. Canadian Journal of Microbiology, 43, 440-446.

Chagas, C. M., Kitajima, E. W., \& Rodrigues, J. C. V. (2003). Coffee ringspot virus vectored by Brevipalpus phoenicis (Acari: Tenuipalpidae) in coffee. Experimental and Applied Acarology, 30, 203-213.

Chandler, D., Davidson, G., Pell, J. K., Ball, B. V., Shaw, K., \& Sunderland, K. D. (2000). Fungal biocontrol of Acari. Biocontrol Science and Technology, 10, 357-384.

Chapman, M. H., \& Hoy, M. A. (1991). Relative toxicity of Bacillus thuringiensis var. tenebrionis to the two-spotted spider mite (Tetranychus urticae Koch) and its predator Metaseiulus occidentalis (Nesbitt) (Acari, Tetranychidae and Phytoseiidae). Journal of Applied Entomology, 11, 147-154. 
Chen, Y., Pettis, J. S., Evans, J. D., Kramer, M., \& Feldlaufer, M. F. (2004). Transmission of Kashmir bee virus by the ectoparasitic mite Varroa Destructor, Apidologie, 35, 441-448.

Chigira, A., \& Miura, K. (2005). Detection of 'candidatus Cardinium' bacteria from the haploid host Brevipalpus californicus (Acari: Tenuipalpidae) and effect on the host. Experimental and Applied Acarology, 37, 107-116.

Dale, C., \& Moran, N. A. (2006). Molecular interactions between bacterial symbionts and their hosts. Cell, 126, 453-465.

De Faria, M. R., \& Wraight, S. P. (2007). Mycoinsecticides and mycoacaricides: A comprehensive list with worldwide coverage and international classification of formulation types. Biological Control, 43, 237-256.

Delalibera, I., De Moraes, G. J., \& Sosa Gomez, D. R. (1999). Epizootias de Neozygites floridana (Zygomycetes, Entomophthorales) e dinâmica populacional de ácaros fitoseídos predadores de Mononychellus tanajoa (Acari, Phytoseiidae e Tetranychidae) na Bahia. Revista Brasileira de Entomologia, 43, 287-291.

Delalibera, I., Hajek, A. E., \& Humber, R. A. (2004). Neozygites tanajoae sp. nov., a pathogen of the cassava green mite. Mycologia, 96, 1002-1009.

Delalibera, I., Sosa Gomez, D. R., De Moraes, G. J., De Alencar, J. A., \& Farias Araujo, W. (1992). Infection of Mononychellus tanajoa (Acari: Tetranychidae) by the fungus Neozygites sp. (Entomophthorales) in northeastern Brazil. Florida Entomologist, 75, 145-147.

De Luna, C. J., Valente Moro, C., Guy, J. H., Zenner, L., \& Sparagano, O. A. E. (2009). Endosymbiotic bacteria living inside the poultry red mite Dermanyssus gallinae). Experimental and Applied Acarology, 48, 105-113.

De Moraes, G. J., \& Delalibera, I. (1992). Specificity of a strain of Neozygites sp. (Zygomycetes: Entomophthorales) to Mononychellus tanajoa (Acari: Tetranychidae). Experimental and Applied Acarology, 14, 89-94.

Dick, G. L., Buschman, L. L., \& Ramoska, W. A. (1992). Description of a species of Neozygites infecting Oligonychus pratensis in the western great plains of the United States. Mycologia, 84, 729-738.

Dissanaike, A.S. (1958). Experimental infection of tapeworms and oribatid mites with Nosema helminthorum. Experimental Parasitology, 7, 306-318.

Dresner, E. (1949). Culture and use of entomogenous fungi for the control of insects. Contributions from Boyce Thompson Institute, 15, 319-335.

Eken, C., \& Hayat, R. (2008) Preliminary evaluation of Cladosporium cladosporioides (Fresen.) de Vries in laboratory conditions, as a potential candidate for biocontrol of Tetranychus urticae Koch. World Journal of Microbiology and Biotechnology, 25, 489-492.

Elliot, S. L. (1998). Ecology and epizootiology of Neozygites floridana, a pathogen of the cassava green mite. PhD Dissertation, Imperial College, Silwood Park, UK, 177pp.

Elliot, S. L., De Moraes, G. J., Delalibera, I., da Silva, C. A. D., Tamai, M. A., \& Mumford, J. D. (2000). Potential of the mite-pathogenic fungus Neozygites floridana (Entomophthorales: Neozygitaceae) for control of the cassava green mite Mononychellus tanajoa (Acari: Tetranychidae). Bulletin of Entomological Research, 90, 1-11.

Elliot, S. L., De Moraes, G. J., \& Mumford, J. D. (2008). Failure of the mite-pathogenic fungus Neozygites tanajoae and the predatory mite Neoselulus idaeus to control a population of the cassava green mite, Mononychellus tanajoa. Experimental and Applied Acarology, 46, 211-222.

Enigi, M., \& Schausberger, P. (2007). Incidence of the endosymbionts Wolbachia, Cardinium and Spiroplasma in phytoiseiid mites and associated prey. Experimental and Applied Acarology, 42, 75-85.

Erhardová, B. (1955). Prvé nálezy Gregarin u roztocu. Ceskoslovenska Parasitologia, 2, 35-37.

Fisher, F. E. (1950). Two new species of Hirsutella Patouillard. Mycologia, 42, 13-16.

Fisher, F. E. (1951). An Entomophthora attacking citrus red mite. The Florida Entomologist, 34, 83-88.

Furtado, I. P., De Moraes, G. J., \& Keller, S. (1996). Infection of Euseius citrifolius (Acari: Phytoseiidae) by an entomophthoralean fungus in Brazil. Rev. Ecossistema, 21, 85-86.

Gardner, W. A., Oetting, R. D., \& Storey, G. K. (1982). Susceptibility of the two-spotted spider mite, Tetranychus urticae Koch, to the fungal pathogen Hirsutella thompsonii Fisher. The Florida Entomologist, 65, 458-465.

Gerson, U., Gafni, A., Paz, Z., \& Sztejnberg, A. (2008). A tale of three acaropathogenic fungi in Israel: Hirsutella, Maira and Acaromyces. Experimental and Applied Acarology, 46, 183-194. 
Gerson, U., Kenneth, R., \& Muttath, T. I. (1979). Hirsutella thompsonii, a fungal pathogen of mites. II. Host-pathogen interactions. Annals of Applied Biology, 91, 29-40.

Gomi, K., Gotoh, T., \& Noda, H. (1997). Wolbachia having no effect on reproductive incompatibility in Tetranychus Kanzawai Kishida (Acari: Tetranychidae). Applied Entomology and Zoology, 32, 485-490.

Gotoh, T., Abe, T., Kurihara, A., \& Suzuki, M. (1995). Genetic incompatibility in local populations of the spider mite, Tetranychus quercivorus Ehara et Gotoh (Acari: Tetranychidae). Applied Entomology and Zoology, 30, 361-368.

Gotoh, T., Gomi, K., \& Nagata, T. (1999a). Incompatibility and host plant differences among populations of Tetranychus kanzawai Kishida (Acari: Tetranychidae). Applied Entomology and Zoology, 34, 551-561.

Gotoh, T., Noda, H., \& Ito, S. (2006). Cardinium symbionts cause cytoplasmic incompatibility in spider mites. Heredity, 98, 13-20.

Gotoh, T., Sugasawa, J., \& Nagata, T. (1999b). Reproductive compatibility of the two-spotted spider mite (Tetranychus urticae) infected with Wolbachia. Entomological Science, 2, 289-295.

Groot, V. M., \& Breeuwer, J. A. J. (2006). Cardinium synbionts induce haploid thelytoky in most clones if three closely related Brevipalpus species. Experimental and Applied Acarology, 39, 257-271.

Guo, Y. L., Zuo, G. S., Zhao, J. H., Wang, N. Y., \& Jiang, J. W. (1993). A laboratory test on the toxicity of thuringiensin to Tetranychus urticae (Acari: Tetranychidae) and Phytoseiulus persimilis (Acari: Phytoseiidae). Chinese Journal of Biological Control, 9, 151-155.

Hajek, A. E. (1997). Ecology of terrestrial fungal entomopathogens. Advances in Microbial Ecology, 15, 193-249.

Hall, I. M., Hunter, D. K., \& Arakawa, K. Y. (1971). The effect of the b-exotoxin fraction of Bacillus thuringiensis on the citrus red mite. Journal of Invertebrate Pathology, 18, 359-362.

Hall, R. A., Hussey, N. W., \& Mariau, D. (1980). Results of a survey of biological control agents of the coconut mite Eriophyes guerreronis. Oleagineux, 35, 395-400.

Hayes, S. F., \& Burgdorfer, W. (1989). Interactions between rickettsial endocytobionts and their tick hosts. In W. Schwemmler \& G. Gassner (Eds.), Insect endocytobiosis: Morphology, physiology, genetics, evolution. Boca Raton, FL: CRC Press.

Herrero-Galán, E., Lacadena, E., Martinez del Pozo, L., Boucias, D. G., Olmo, N., Oñadera, M., \& Gavilanes, J. G. (2008). The insecticidal protein hirsutellin A from the mite pathogen Hirsutella thompsonii is a ribotoxin. Proteins, 72, 217-228.

Hess, R. T., \& Hoy, M. A. (1982). Microorganisms associated with the spider mite predator Metaseiulus (Typhlodromus) occidentalis: Electron microscope observations. Journal of Invertebrate Pathology, 40, 98-106.

Hountondji, F. C. C. (2005). Classical microbial control of the cassava green mite. From individual behaviour to population dynamics. Ph.D. Dissertation, University of Amsterdam, The Netherlands, 150 pp.

Hountondji, F. C. C. (2008). Lessons from interactions within the cassava green mite fungal pathogen Neozygites tanajoae system and prospects for microbial control using Entomophthorales. Experimental and Applied Acarology, 46, 195-210.

Hoy, M. A., \& Jeyaprakash, A. (2008). Symbionts, including pathogens, of the predatory mite Metaseiulus occidentalis: Current and future analysis. Experimental and Applied Acarology, 46, 329-347.

Hoy, M. A., \& Ouyang, Y.-L. (1987). Toxicity of b-exotoxin of Bacillus thuringiensis to Tetranychus pacificus and Metaseiulus occidentalis (Acari: Tetranychidae and Phytoseiidae). Journal of Economic Entomology, 80, 507-511

Hughes, T. E. (1950). The physiology of the alimentary canal of Tyrophagus farinae. The Quarterly Journal of Microscopical Science, 91, 98-106.

Humber, R. A. (1992). Collection of Entomopathogenic Fungi: Catalog of Strains 1992. Agricultural Research Service Publications, 110, 177.

Humber, R. A., De Moraes, G. J., \& Dos Santos, J. M. (1981). Natural infection of Tetranychus evansi (Acarina: Tetranychidae) by a Triplosporium sp. (Zygomycetes: Entomophthorales) in northeastern Brazil. Entomophaga, 26, 421-425.

Issi, I. V., \& Lipa, J. (1968). Gurleya sokolovi sp.n., a microsporidian parasite of the water mite Limnochares aquatica (Linnaeus) (Acarina: Hydrachnellae), and a note on a gregarine infection in the same mite. Journal of Invertebrate Pathology, 10, 165-175.

Jaeniki, J., Polak, M., Fiskin, A., Helou, M., \& Minhas, M. (2007). Interspecific transmission of endosymbiotic Spiroplasma by mites. Biology Letters, 3, 23-25. 
James, D. G. (1994). Biological control of earth mites in pasture using endemic natural enemies (pp. 69-71). Proceedings of the 2nd National Workshop on Redlegged Earth Mite, Lucerne Flea and Blue Oat Mite. Rutherglen, Victoria, Australia.

Johanowicz, D. L., \& Hoy, M. A. (1996). Wolbachia in a predator-prey system: 16S ribosomal DNA analysis of two phytoseiids (Acari: Phytoseiidae) and their prey (Acari: Tetranychidae). Annals of the Entomological Society of America, 89, 435-441.

Jung, Y.-C., Mizuki, E., Akao, T., \& Côté, J. C. (2007). Isolation and characterization of a novel Bacillus thuringiensis strain expressing a novel crystal protein with cytocidal activity against human cancer cells. Journal of Applied Microbiology, 103, 65-79.

Kanga, L. H. B., James, R. R., \& Boucias, D. G. (2002). Hirsutella thompsonii and Metarhizium anisopliae as potential microbial control agents of Varroa destructor, a honey bee parasite. Journal of Invertebrate Pathology, 81, 175-184.

Keller, S. (1997). The genus Neozygites (Zygomycetes, Entomophthorales) with special reference to species found in tropical regions. Sydowia, 49, 118-146.

Keller, S., \& Wuest, J. (1983). Observations sur trois espèces de Neozygites (Zygomycetes: Entomophthoraceae). Entomophaga, 28, 123-134.

Kleespies, R. G., Radtke, J., \& Bienefield, K. (2000). Virus-like particles found in the ectoparasitic bee mite Varroa jacobsoni Oudemans. Journal of Invertebrate Pathology, 75, 87-90.

Klingen, I., Wærsted, G., \& Westrum, K. (2008). Overwintering and prevalence of Neozygites floridana (Zygomycetes: Neozygitaceae) in hibernating females of Tetranychusurtcae (Acari: Tetranychidae) under cold climatic conditions in strawberries. Experimental and Applied Acarology, 46, 231-245.

Kondo, H., Maeda, T., \& Tamada, T. (2003). Orchid fleck virus: Brevipalpus californicus mite transmission, biological properties and genome structure. Experimental and Applied Acarology, 30, 215-233.

Krieg, A. (1972). Über die Wirkung von Bacillus thuringiensis-Präparaten auf Spinnmilbe (Tetranychidae). Anzeiger für Schädlingskunde, Pflanzenschutz, Umweltschutz, 45, 169-171.

Kumar, P. L., Duncan, G. H., Robert, I. M., Jones, A. T., \& Reddy, D. V. R. (2002). Cytopathology of Pigeonpea sterility mosaic virus in pigeonpea and Nicotiana benthamiana: Similarities with those of eriophyid mite-borne agents of undefined aetiology. Annals of Applied Biology, 140, 87-96.

Larsson, J. I. L. (1990). Description of a new microsporidium of the water mite Limnochares aquatica and establishment of the new genus Napamichum (Microspora, Thelohaniidae). Journal of Invertebrate Pathology, 55, 152-161.

Larsson, J. I. R., Steiner, M. Y., \& Bjørnson, S. (1997). Intexta acarivora gen. et sp. n. (Microspora: Chytridiopsidae) - Ultrastructural study and description of a new microsporidian parasite of the forage mite Tyrophagus putrescentiae (Acari: Acaridae). Acta Prozoologica, 36, 295-304.

Leatherdale, D. (1965). Fungi infecting rust and gall mites (Acarina: Eriophyidae). Journal of Invertebrate Pathology, 7, 325-328.

Leite, L. G., Smith, L, De Moraes, G. J., \& Roberts, D. W. (2000). In vitro production of hyphal bodies of the mite pathogenic fungus Neozygites floridana. Mycologia, 92, 201-207.

Lewis, G. C., Heard, A. J., Brady, B. L., \& Minter, D. W. (1981). Fungal parasitism of the eriophyid mite vector of rye grass mosaic virus. Proceedings of the 1981 British Crop Protection Conference on Pests and Diseases, pp. 109-111.

Lighthart, B., Sewall, D., \& Thomas, D. R. (1988). Effect of several stress factors on the susceptibility of the predatory mite, Metaseiulus occidentalis (Acari: Phytoseiidae), to the weak bacterial pathogen Serratia marcescens. Journal of Invertebrate pathology, 52, 33-42.

Lipa, J. J. (1962). Nosema sperchoni n. sp. (Microspordia), a new parasitic protozoan from the water mite Sperchon sp. (Hydracarina, Acarina). Bulletin of the Polish Academy of Sciences, Biological Sciences, $20,435-437$.

Lipa, J .J. (1971). Microbial control of mites and ticks. H. D. Burges \& N. W. Hussey (Eds.). In H. D. Burges \& N. W. Hussey (Eds.), Microbial control of insects and mites (pp. 357-373). New York: Academic Press.

Lipa, J. J. (1982). Nosema euzeti sp. n. and Gregarine euzeti sp. n., two new protozoan parasites of a mite Euzetes seminulum (O. F. Miller) (Acarina, Oribatei). Acta Protozoologica, 21, 121-126.

Liu, T. P. (1991). Virus-like particles in the tracheal mite Acarapis woodi (Rennie). Apidolologie, 22, 213-219.

Maimala, S., A. Tartar, A., Boucias, D., \& Chandrapatya, A. (2002). Detection of the toxin hirsutellin A from Hirsutella thompsonii. Journal of Invertebrate Pathology, 80, 112-126. 
Maiti P. K., Bose, R., Bandyopadhyay, S., Bhattacharya, S., Dey, J. B., \& Ray, A. (2004). Entomophthoromycosis in South Bengal (Eastern India): A 9 years study. Indian Journal of Pathology and Microbiology, 47, 295-297.

Maketon, M., Orosz-Coghlan, P., \& Sinprasert, J. (2008). Evaluation of Metarhizium anisopliae (Deuteromycota: Hyphomycetes) for control of broad mite Polyphagotarsonemus latus (Acari: Tarsonemidae) in mulberry. Experimental and Applied Acarology, 46, 157-167.

Malone, L. A., \& McIvor, C. A. (1996). Use of nucleotide sequence data to identify a microsporidian pathogen of Pieris rapae (Lepidoptera, Pieridae). Journal of Invertebrate Pathology, 68, 231-238.

Maniania, N. K., Bugeme, D. M., Wekesa, V. W., Delalibera, I., \& Knapp, M., (2008). Role of entomopathogenic fungi in the control of Tetranychus evansi and Tetranychus urticae (Acari: Tetranychidae), pests of horticultural crops. Experimental and Applied Acarology, 46, 259-274.

McCoy, C. W. (1981). Pest control by the fungus Hirsutella thompsonii. In H. D. Burges (Ed.). Microbial control of insects, mites and plant diseases (pp. 499-512), New York: Academic Press.

McCoy, C. W. (1996). Pathogens of eriophyoids. In E. E. Lindquist, M. W. Sabelis, \& J. Bruin (Eds.), Eriophyoid mites - their biology, natural enemies and control (pp. 481-490). Amsterdam: Elsevier.

McCoy, C. W., Hill, A. J., \& Kanavel, R. F. (1975). A liquid medium for the large-scale production of Hirsutella thompsonii in submerged culture. Journal of Invertebrate Pathology, 19, 370-374.

McCoy, C. W., \& Selhime, A. G. (1977). The fungus pathogen, Hirsutella thompsonii and its potential use for control of the citrus mite in Florida (Vol. 2, pp. 521-527). Proceedings of the International Citrus Congress, Murcia, Spain.

McEnroe, W. D. (1961). Guanine excretion by the two-spotted spider mite (Tetranychus telarius (L.)). Annals of the Entomological Society of America, 54, 926-926.

Meikle, W. G., Mercadier, G., Holst, N., \& Girod, V. (2008). Impact of two treatments of formulation of Beauveria bassiana (Deuteromycota: Hyphomycetes) conidia on Varroa mites (Acari: Varroidae) and on honeybee (Hymenoptera: Apidae) colony health. Experimental and Applied Acarology, 46, 105-117.

Miętkiewski, R., \& Bałazy, S. (2003). Neozygites abacaridis sp. nov. (Entomophthorales), a new pathogen of phytophagous mites (Acari, Eriophyidae). Journal of Invertebrate Pathology, 83, 223-229.

Miętkiewski, R., Bałazy, S., \& Tkaczuk, C. (2000). Mycopathogens of Mites in Poland - A Review. Biocontrol Science and Technology, 10, 459-465.

Miețkiewski, R., Bałazy, S., \& Van der Geest, L. P. S. (1993). Observations on a mycosis of spider mites (Acari: Tetranychidae) caused by Neozygites floridana in Poland. Journal of Invertebrate Pathology, 61, 317-319.

Milner, R. J. (1985). Neozygites acaridis (Petch) comb. nov.: An entomophthoralean pathogen of the mite, Macrocheles peregrinus, in Australia. Transactions of the British Mycological Society, 85, 641-647.

Minter, D. W., Brady, B. L., \& Hall, R. A. (1983). Five Hyphomycetes isolated from eriophyid mites. Transactions of the British Mycological Society, 81, 455-471.

Moniez, R. 1887. Observations pour la révision des Microsporidies. Comptes Rendus de l'Académies des Sciences, 104, 1312-1314.

Moore-Landecker, E. (1996). Fundamentals of the Fungi, (4th ed., 574pp). Upper Sadle River, New Jersey: Prentice Hall.

Muma, M. H. (1955). Factors contributing to the natural control of citrus insects and mites in Florida. Journal of Economic Entomology, 48, 432-438.

Munderloh, U. G., \& Kurtti, T. J. (1995). Cellular and molecular interrelationships between ticks and prokaryotic tick-borne pathogens. Insect Molecular Biology, 3, 63-66.

Nemoto, H., Kobayashi, M., \& Takizawa, Y. (1975). Entomophthora floridana (Entomophthorales: Entomophthoraceae) attacking the sugi spider mite, Oligonychus hondoensis (Acari: Tetranychidae), in Japan. Applied Entomology and Zoology, 10, 90-95.

Nyiira, Z. M. (1982). Cassava green mite: Its distribution and possible control (pp. 65-67). Root Crops in Africa: Proceedings of a Workshop held in Kigali, Ruanda, 23-27 November 1980. International Development Research Centre, Ottawa, Canada.

Odongo, B., Odindo, M. O., Brownbridge, M., \& Kumar, R. (1998). Comparative biological efficacy of Hirsutella thompsonii and Neoseiulus teke for cassava mite (Mononychellus tanajoa) suppression. Bioscience Technology, 8, 345-355.

Oduor, G. I. (1995c). Abiotic factors and the epizootiology of Neozygites cf. floridana, a fungus pathogenic to the cassava green mite. PhD Dissertation, University of Amsterdam, 101pp. 
Oduor, G. I., De Moraes, G. J., Van der Geest, L. P. S., \& Yaninek, J. S. (1996a). Production and germination of primary conidia of Neozygites floridana (Zygomycetes: Entomophthorales) under constant temperatures, humidities, and photoperiods). Journal of Invertebrate Pathology, 68, 213-222.

Oduor, G. I., De Moraes, G. J., Van der Geest, L. P. S., \& Yaninek, J. S. (1997a). The effect of pathogen dosage on the pathogenicity of Neozygites floridana (Zygomycetes: Entomophthorales) to Mononychellus tanajoa (Acari: Tetranychidae). Journal of Invertebrate Pathology, 70, 127-130.

Oduor, G. I., De Moraes, G. J., Yaninek, J. S., \& Van der Geest, L. P. S. (1995a). Effect of temperature, humidity and photoperiod on mortality of Mononychellus tanajoa (Acari: Tetranychidae) Infected by Neozygites cf. floridana (Zygomycetes: Entomophthorales). Experimental and Applied Acarology, 19, 571-579.

Oduor, G. I., Sabelis, M. W., Lingeman, R., De Moraes, G. J., \& Yaninek, J. S. (1997b). Modelling fungal (Neozygites cf. floridana) epizootics in local populations of cassava green mite (Mononychellus tanajoa). Experimental and Applied Acarology, 21, 485-506.

Oduor, G. I., Yaninek, J. S., Van der Geest, L. P. S., \& De Moraes, G. J. (1995b). Survival of Neozygites cf. floridana (Zygomycetes: Entomophthorales) in mummified cassava green mites and the viability of its primary conidia. Experimental and Applied Acarology, 19, 479-488.

Oduor, G. I., Yaninek, J. S., Van der Geest, L. P. S., \& De Moraes, G. J. (1996b). Germination and viability of capilliconidia of Neozygites floridana (Zygomycetes: Entomophthorales) under constant temperature, humidity and light conditions). Journal of Invertebrate Pathology, 67, 267-278.

Omoto, C., \& McCoy, C. W. (1998). Toxicity of purified fungal toxin hirsutellin A to the citrus rust mite Phyllocoptruta oleivora (Ash). Journal of Invertebrate Pathology, 72, 319-322.

Ongus, J. R. (2006). Varroa destructor virus 1: A new picorna-like virus in Varroa mites as well as honey bees. Ph.D. Dissertation, Wageningen University, The Netherlands, 132pp.

Ongus, J. R., Peters, D., Bonmatin, J. M., Bengsch, E., Vlak, J. M., \& Van Oers, M. M. (2004). Complete sequence of a picorna-like virus of the genus Iflavirus replicating in the mite Varroa destructor. Journal of General Virology, 85, 3747-3755.

Paliwal, Y. C. (1972). Brome mosaic virus infection in the wheat curl mite Aceria tulipae, a nonvector of the virus. Journal of Invertebrate Pathology, 20, 288-302.

Payne, J., Cannon, R. J. C., \& Bagley, A. L. (1993). Bacillus thuringiensis isolates for controlling acarides (8pp). US Patent 5,211,946.

Payne, J., Cannon, R. J. C., \& Ralph, A. L. (1994). Bacillus thuringiensis isolates for controlling acarides (20pp). US Patent 5,350,576.

Peña, J. E., Osborne, L. S., \& Duncan, R. E. (1996). Potential of fungi as biocontrol agents of Polyphagotarsonemus latus (Acari: Tarsonemidae). Entomophaga, 41, 27-36.

Poinar, G. Jr., \& Poinar, R. (1998). Parasites and pathogens of mites. Annual Reviews of Entomology, 43, 449-469.

Pukall, R., Schumann, P., Schütte, C., Gols, R., \& Dicke, M. (2006). Acaricomes phytoseiuli gen. nov., sp. nov., isolated from the predatory mite Phytoseiulus persimilis. International Journal of Systematic Evolutionary Microbiology, 56, 465-469.

Purrini, K. (1984). Two new coccidian parasites of the genus Adelina (Adeleidae, Coccidia) parasitizing oribatid mite Nothrus silvestris (Oribatei, Acarina) and springtail Neanura muscorum (Collembola, Apterygota) in forest soil. Archiv für Protistenkunde, 128, 99-107.

Purrini, K., \& Bäumler, W. (1976). Nosema ptyctimae n. sp., eine neue Mikrosporidie aus Rhysotritia ardua C. L. Koch (Fam. Phthiracaridae, Ptyctima, Acarina). Anzeiger für Schädlingskunde, Pflanzenschutz, Umweltschutz, 49, 169-171.

Purrini, K., Bukva, V., \& Bäumler, W. (1979). Sporozoen in Hornmilben (Oribatei, Acarina) aus Waldböden Süddeutschlands nebst Beschreibug von Gregarina postneri n.sp. und G. fuscozetis n. $\mathrm{sp}$. (Gregarinida, Sprorozoa, Protozoa). Pedobiologia, 19, 329-339.

Purrini, K., \& Ormieres, R. (1981). Uber vier neue Eugregarinen-Arten (Eugregrarinida, Sporozoa) der Hornmilben (Oribatei, Acarina). Zoologische Beitraege, 27, 123-132.

Purrini, K. \& Weiser, J. (1981). Eight new microsporidian parasites of moss-mites (Oribatei, Acarina) in forest soil. Zeitschrift fuer Angewandte Entomologie, 91, 217-224.

Putman, W. L. (1970). Occurrence and transmission of a virus disease of the European red mite, Panonychus ulmi. The Canadian Entomologist, 102, 305-321.

Putman, W. L., \& Herne, D. H. C. (1966). The role of predators and other biotic agents in regulating the population density of phytophagous mites in Ontario peach orchards. The Canadian Entomologist, 98 , 808-820. 
Ramaseshiah, G. (1971). Occurrence of an Entomophthora on tetranychid mites in India. Journal of Invertebrate Pathology, 24, 218-223.

Reed, D. K. (1981). Control of mites by non-occluded viruses. In H. D. Burges (Ed.), Microbial control of pests and plant Diseases 1970-1980 (pp. 427-432). New York: Academic Press.

Reed, D. K., \& Desjardins, P. R. (1978). Isometric virus-like particles from citrus red mites, Panonychus citri. Journal of Invertebrate Pathology, 31, 188-193.

Reed, D. K., \& Hall, I. M. (1972). Electron microscopy of a rod-shaped non-inclusion virus infecting the citrus red mite, Panonychus citri. Journal of Invertebrate Pathology, 20, 272-278.

Rodrigues, J. C. V., Kitajima, E. W., Childers, C. C., \& Chagas, C. M. (2003). Citrus leprosies virus vectored by Brevipalpus phoenicis (Acari: Tenuipalpidae) on citrus in Brazil. Experimental and Applied Acarology, 30, 161-179.

Rombach, M. C. \& Gillespie, A. T. (1988). Entomogenous Hyphomycetes for insect and mite control on greenhouse crops. Biocontrol News and Information, 9, 7-18.

Royalty, R. N., Hall, F. R., \& Taylor, R. A. J. (1990). Effects of thuringiensin on Tetranychus urticae (Acari: Tetranychidae) mortality, fecundity, and feeding. Journal of Economic Entomology, 83, 792-798.

Saba, F. (1971). Population dynamics of some tetranychids in subtropical Florida (pp. 237-240). Proceedings 3rd International Congress of Acarology. Prague, The Hague, Junk.

Saleh, S. M., Kelada, N. L., \& Shader, N. (1991). Control of European house dust mite Dermatophagoides pteronyssinus (Trouessart) with Bacillus spp. Acarologia, 32, 257-260.

Samish, M., \& Řeháček, J. (1999). Pathogens and predators of ticks and their potential in biological control. Annual Review of Entomology, 44, 159-182.

Sammataro, D., Gerson, U., \& Needham, G. (2000). Parasitic mites of honey bees: Life history, implications and impact. Annual Reviews of Entomology, 45, 519-548.

Samson, R. A. (1981). Identification: Entomopathogenic deuteromycetes. In (H. D. Burges, (Ed.), Microbial control of pests and plant diseases 1970-1980 (pp. 93-106). New York: Academic Press.

Samson, R. A., \& McCoy, C. W. (1982). A new fungal pathogen of the scavenger mite, Tydeus gloveri. Journal of Invertebrate Pathology, 40, 216-220.

Sanassi, A., \& Amirthavalli, S. (1970). Infection of the velvet mite, Thrombidium gigas by Aspergillus flavus. Journal of Invertebrate Pathology, 16, 54-56.

Sanassi, A., \& Oliver, J. H. (1971). Integument of the velvet-mite, Dinothrombium giganteum, and histopathological changes caused by the fungus Aspergillus flavus. Journal of Invertebrate Pathology, $17,354-365$.

Schütte, C. (2006). A novel bacterial disease of the predatory mite Phytoseiulus persimilis: Disease syndrome, disease transmission and pathogen isolation. Ph.D. dissertation. Wageningen University, The Netherlands, 208pp.

Schütte, C., \& Dicke, M. (2008). Verified and potential pathogens of predatory mites (Acari: Phytoseiidae). Experimental and Applied Acarology, 46, 307-328.

Selhime, A. G., \& Muma, M. H. (1966). Biology of Entomophthora floridana attacking Eutetranychus banksi. The Florida Entomologist, 49, 161-168.

Shaw, J. G., Chambers, D. L., \& Tashiro, H. (1968). Introducing and establishing the noninclusion virus of the citrus red mite in citrus groves. Journal of Economic Entomology, 61, 1352-1355.

Shaw, J. G., Moffitt, C., \& Sciven, G. T. (1967). Biotic potential of phytoseiid mites fed on virus-infected citrus red mites. Journal of Economic Entomology, 60, 1751-1752.

Shen, M., Yang X., Cox-Foster, D., \& Cui, L. (2005). The role of varroa mites in infections of Kashmir bee virus (KBV) and deformed wing virus (DWV) in honey bees. Virology, 342, 141-149.

Shi, W. B., Feng, M. G., \& Liu, S. S. (2008). Sprays of emulsifiable Beauveria bassiana forkulation are ovcidal towards Tetranychus urticae (Acari: Tetranychidae) at various regimes of temperature and humidity. Experimental and Applied Acarology, 46, 247-257.

Smith, J. W., \& Furr, R. E. (1975). Spider mites and some natural control agents found in cotton in the Delta area of Mississippi. Environmental Entomology, 4, 559-560.

Smith, K. M., \& Cressman, A. W. (1962). Birefringent crystals in virus-diseased citrus red mites. Journal of Insect Pathology, 4, 229-236.

Smith, K. M., Hill, G. J., Munger, F., \& Gilmore, J. E. (1959). A suspected virus disease of the citrus red mite Panonychus citri. Nature, 184, 70 .

Sosa Gomez, D. R., \& Moscardi, F. (1991). Microbial control and insect pathology in Argentina. Ciência e Cultura, 43, 375-379. 
Speare, A. T., \& Yothers, W. W. (1924). Is there an entomogenous fungus attacking the citrus rust mite in Florida? Science, 40, 41-42.

Sprague, V., Becnel, J. J., \& Hazard, E. I. (1992). Taxonomy of phylum Microspora. Critical Reviews in Microbiology, 18, 285-395.

Sreerama Kumar, P. L., \& Singh S. P. (2008). Enabling mycelial application of Hirsutella thompsonii for managing the coconut mite. Experimental and Applied Acarology, 46, 169-182.

Sreerama Kumar, P. (2006). Hirsutella thompsonii as a mycoacaricide for Aceria guerreronis on coconut in India: Research, development and other aspects. Abstracts 12th International Congress of Acarology, August 2006. Amsterdam, The Netherlands, p. 198.

Sreerama Kumar, P., \& Singh, S. P. (2001). Coconut mite in India: Biopesticicide breakthrough. Biocontrol News and Information, 22, 76N-77N.

Steiner, M. (1993). Quality control requirements for pest biological control agents. Alberta Government Publication AECV93-R6. Alberta Environmental Centre, Vegrevile, AB.

Steinhaus, E. A. (1949). Principles of insect pathology (757pp). McGraw-Hill: New York.

Steinhaus, E. A. (1959). Possible virus disease in European red mite. Journal of Insect Pathology, 1, 435-437.

Steinhaus, E. A., \& Marsh, G. A. (1962). Reports of diagnosis of diseased insects. 1951-1961. Hilgardia, 33, 349-490.

Susilo, F. X., Nordin, G. L., \& Brown, G. C. (1994). Age-specific and inter-sexual susceptibility of twospotted spider mite, Tetranychus urticae Koch, to Neozygites floridana Weiser and Muma. Journal of the Kansas Entomological Society, 67, 293-296.

Šut'áková, G. (1988). Electron microscopic study of developmental stages of Rickettsiella phytoseiuli in Phytoseiulus persimilis Athias-Henriot (Gamasoidea: Phytoseiidae) mites. Acta Virologica, 32, 50-54.

Šut'áková, G. (1994). Phenomenon of Rickettsiella phytoseiuli in Phytoseiulus persimilis mite. Acta microbiol. Acta Microbiologica et Immunologica Hungarica, 41, 411-414.

Sztejnberg, A., Doron-Shloush, S., \& Gerson, U. (1997). The biology of the acaropathogenic fungus Hirsutella kirchneri. Biocontrol Science and Technology, 7, 577-590.

Tamai, M. A., Alves, S. B., Lopes, R. B., \& Neves, P. S. (1998). Avaliação de fungos entomopatogênicos para o controle de Tetranychus urticae Koch (p. 1066). Abstracts 17th Congress of Entomology, Rio de Janeiro, Brazil.

Tanada, Y., \& Kaya, H. K. (1993). Insect pathology (666pp). New York: Academic Press.

Tanigoshi, L. K. (1982). Advances in the knowledge of the biology of the Phytoseiidae. In M. Hoy (Ed.), Recent advances in knowledge of phytoseiidae (pp. 1-22). Division of Agricultural Sciences, Special Publication 3284. Berkeley: University of California.

Tanigoshi, L. K., Fagerlund, J., \& Nishio-Wong, J. Y. (1981). Significance of temperature and food resources to the developmental biology of Amblyseius hibisci (Chant) (Acarina, Phytoseiidae). Zeitschrift fuer Angewandte Entomologie, 92, 409-419.

Tanzini, M. R., Alves, S. B., Tamai, M. A., De Moraes, G. J., \& Ferla, N. J. (2000). An epizootic of Calacarus heveae (Acari: Eriophyidae) by Hirsutella thompsonii on rubber trees. Experimental and Applied Acarology, 24, 141-144.

Thomas, G. M., \& Poinar, G. O. (1973). Report of diagnoses of diseased insects. Hilgardia, 42, 261-360.

Tsagkarakou, A., Guillemaud, T., Rousset, F., \& Navajas, M. (1996). Molecular identification of a Wolbachia endosymbiont in a Tetranychus urticae strain (Acari: Tetranychidae). Insect Molecular Biology, 5, 217-221.

Urueta, E. J. (1980). Control del ácaro Retracus elaeis Keifer mediante el hongo Hirsutella thompsonii Fisher y inhibición de este por dos fungicidas. Revista Colombiana de Entomología, 6, 3-9.

Valiente Moro, C., Chauve, C., \& Zenner, L. (2005). Vectorial role of some dermanyssoid mites (Acari, Mesostigmata, Dermanyssoidea). Parasite, 12, 99-109.

Van der Geest, L. P. S. (1985). Pathogens of spider mites. In W. Helle \& M. W. Sabelis (Eds.), Spider mites. Their biology, natural enemies and control (Vol. 1B, pp. 247-258). Amsterdam: World Crop Pests.

Van der Geest, L. P. S. (2004). Schimmels als belagers van schadelijke mijten op planten. Entomologische Berichten (Amsterdam), 64, 146-156.

Van der Geest, L. P. S., De Moraes, G. J., Navia, D., \& Tanzini, M. R. (2002). New records of pathogenic fungi in mites (Arachnida: Acari) from Brazil. Neotropical Entomology, 31, 493-495.

Van der Geest, L. P. S., Elliot, S. L., Breeuwer, J. A. J., \& Beerling, E. A. M. (2000). Diseases of mites. Experimental and Applied Acarology, 27, 497-560. 
Van Dijk, P., \& Van der Vlugt, R. A. A. (1994). New mite-borne isolates from rakkyo, shallot and wild leek species. European Journal of Plant Pathology, 100, 269-277.

Van Opijnen, T., \& Breeuwer, J. A. J. (1999). High temperatures eliminate Wolbachia, a cytoplasmic incompatibility inducing endosymbiont, from the two-spotted spider mite. Experimental and Applied Acarology, 23, 871-881.

Vey, A., Quiot, J. M., Mazet, I., \& McCoy, C. W. (1993). Toxicity and pathology of crude broth filtrate produced by Hirsutella thompsonii var. thompsonii in shake culture. Journal of Invertebrate Pathology, 61, 131-137.

Walter, D. L. (1999). Cryptic inhabitants of a noxious weed: Mites (Arachnida: Acari) on Lantana camara L. invading forests in Queensland. Australian Journal of Entomology, 38, 197-200.

Weeks, A. R., \& Breeuwer, J. A. J. (2001). Wolbachia-induced parthenogenesis in a genus of phytophagous mites. Proceedings of the Royal Society of London, Series B: Biological Sciences, 268, 2245-2251.

Weiser, J. (1956). Nosema steinhausi n.sp., nova mikrosporidie z rostoãe Tyrophagus noxius (Acarina, Tyroglyphidae). Ceskoslovenska Parasitologie, 11, 187-192.

Weiser, J. (1968). Triplosporium tetranychi sp.n. (Phycomycetes: Entomophthoraceae), a fungus infecting the red spider mite Tetranychus althaeae Hanst. Folia Parasitologica, 15, 115-122.

Weiser, J., \& Muma, M. H. (1966). Entomophthora floridana n. sp. (Phycomycetes: Entomophthoraceae), a parasite of the Texas citrus mite Tetranychus banksi. The Florida Entomologist, 49, 155-159.

Weiss, E., \& Moulder, J. W. (1984). Order I. Rickettsiales Gieszczkiewicz. In N. R. Krieg \& J. G. Holt (Eds.). Bergey's Manual of Systematic bacteriology (Vol. 1). Williams and Wilkins: Baltimore.

Yaninek, J. S. (1988). Continental dispersal of the cassava green mite, an exotic pest in Africa, and implications for biological control. Experimental and Applied Acarology, 4, 211-224.

Yaninek, J. S., Saizonou, S., Onzo, A., Zannou, I., \& Gnanvossou, D. (1996). Seasonal and habitat variability in the fungal pathogens, Neozygites cf. floridana and Hirsutella thompsonii, associated with cassava green mites in Benin, West Africa. Biocontrol Science and Technology, 6, 23-33. 